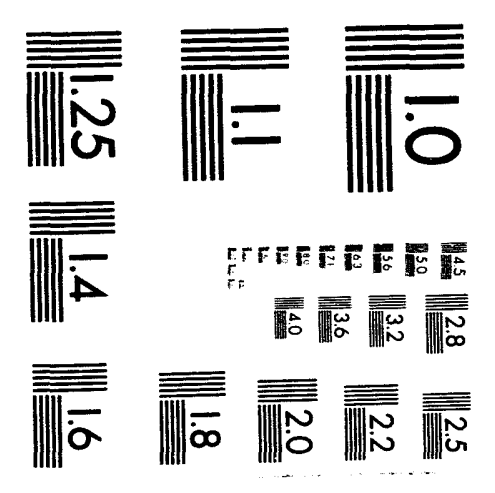


Distribution

Category UC-610

SAND93-3808

Unlimited Release

Printed January 1994

\title{
Air Ingression Calculations for Selected Plant Transients using MELCOR
}

\author{
L. N. Kmetyk \\ Thermal/Hydraulic Analysis Department \\ Sandia National Laboratories \\ Albuquerque, NM 87185-5800
}

\begin{abstract}
Two sets of MELCOR calculations have bcen completed studying the effects of air ingression on the consequences of various severe accident scenarios. One set of calculations analyzed a station blackout with surge line failure prior to vessel breach, starting from nominal operating conditions; the other set of calculations analyzed a station blackout occurring during shutdown (refueling) conditions. Both sets of analyses were for the Surry plant, a three-loop Westinghouse PWR. For both accident scenarios, a basecase calculation was done, and then repeated with air ingression from containment into the core region following core degradation and vessel failure.

In addition to the two sets of analyses done for this program, a similar air-ingression sensitivity study was done as part of a low-power/shutdown PRA, with results sumnarized here; that PRA study also analyzed a station blackout occurring during shutdown (refueling) conditions, but for the Grand Gulf plant, a BWR/6 with Mark III containment.

These studies help quantify the amount of air that would have to enter the core region to have a significant impact on the severe accident scenario, and demonstrate that one effect of air ingression is substantial enhancement of ruthenium release. These calculations also show that, while the core clad temperatures rise more quickly due to oxidation with air rather than steam, the core also degrades and relocates more quickly, so that no sustained, enhanced core heatup is predicted to occur with air ingression.
\end{abstract}




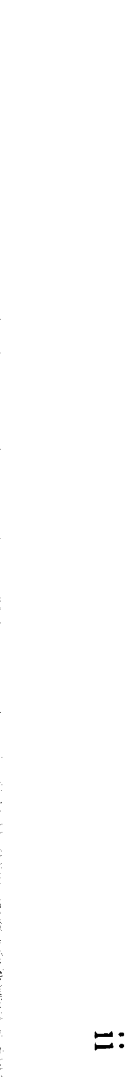




\section{Contents}

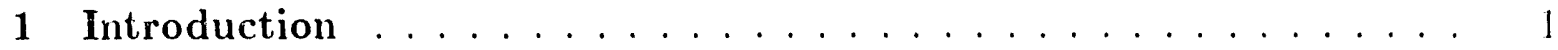

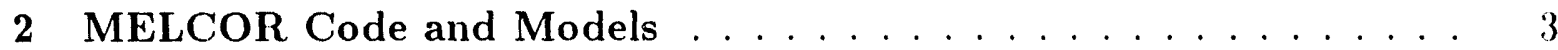

3 MELCOR Surry Midloop Calculations with Air Ingression . . . . . 5

4 MELCOR Surry TMLB' Calculations with Surge Line Break and Air Ingression . . . . . . . . . . . . . . . . . 35

5 MELCOR Grand Gulf Low-Power/Shutdown Calculations with Air Ingression . . . . . . . . . . . . . . . . . . . . 63

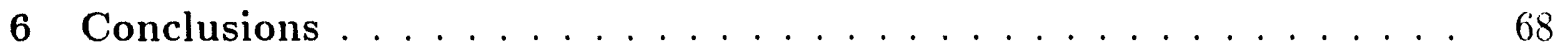

Bibliography ......................... 70 


\section{List of Figures}

3.1 Reference MELCOR COR Input Model for Surry Core . . . . . . . . . 7

3.2 Core Ring 1 Fuel/Clad Component Materials at Vessel Failure in MELCOR Surry Midloop Calculations with Air Ingression . . . . . . . . . . . 9

3.3 Core Ring 2 Fuel/Clad Component Materials at Vessel Failure in MELCOR Surry Midloop Calculations with Air Ingression . . . . . . . . . . . 10

3.4 Core Ring 3 Fuel/Clad Component Materials at Vessel Failure in MELCOR Surry Midloop Calculations with Air Ingression . . . . . . . . . . 11

3.5 Core Ring 1 Particulate Debris Component Materials at Vessel Failure in MELCOR Surry Midloop Calculations with Air Ingression . . . . . . . . 12

3.6 Core Ring 2 Particulate Debris Component Materials at Vessel Failure in MELCOR Surry Midloop Calculations with Air Ingression . . . . . . . . 13

3.7 Core Ring 3 Particulate Debris Component Materials at Vessel Failure in MELCOR Surry Midloop Calculations with Air Ingression . . . . . . . 14

3.8 Core Ring 1 Other Structure Component Materials at Vessel Failure in MELCOR Surry Midloop Calculations with Air Ingression . . . . . . . . 15

3.9 Core Ring 2 Other Structure Component Materials at Vessel Failure in MELCOR Surry Midloop Calculations with Air Ingression . . . . . . . .

3.10 Core Ring 3 Other Structure Component Materials at Vessel Failure in MELCOR Surry Midloop Calculations with Air Ingression . . . . . . . .

3.11 Core Active Fuel Region Steam Mole Fractions in MELCOR Surry Midloop Calculations with Air Ingression . . . . . . . . . . . .

3.12 Core Active Fuel Region Nitrogen Mole Fractions in MELCOR Surry Midloop Calculations with Air Ingression . . . . . . . . . . . .

3.13 Core Active Fuel Region Oxygen Mole Fractions in MELCOR Surry Midloop Calculations with Air Ingression . . . . . . . . . .

3.14 Core Active Fuel Region Hydrogen Mole Fractions in MELCOR Surry Midloop Calculations with Air Ingression . . . . . . . . . . . . .

3.15 Core Average Clad Temperatures in MELCOR Surry Midloop Calculations with Air Ingression . . . . . . . . . . . . . . . . .

3.16 Core Maximum Clad Temperatures in MELCOR Surry Midloop Calculations with Air Ingression . . . . . . . . . . . . . .

3.17 Core Ring 2, Level 5 Clad Temperatures in MELCOR Surry Midloop Calculations with Air Ingression . . . . . . . . . . . .

3.18 Core Ring 2, Level 9 Clad Temperatures in MEI_COR Surry Midloop Calculations with Air Ingression . . . . . . . . . . . 
3.19 Total Core Masses in MELCOR Surry Midloop Calculations with Air In-

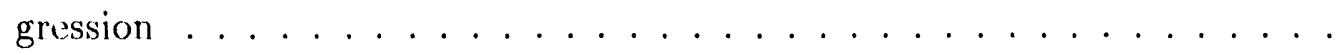

3.20 Core Average Debris Temperatures in MELCOR Surry Midloop Calculations with Air Ingression . . . . . . . . . . . . . . . .

3.21 Core Maximum Debris Temperatures in MELCOR Surry Midloop Calculations with Air Ingression . . . . . . . . . . . . . .

3.22 Lower Plenum Volume Vapor Flows in MELCOR Surry Midloop Calcula-

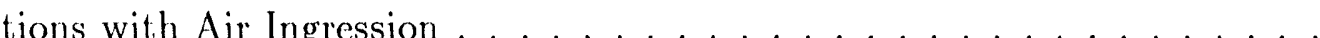

4.1 Core Liquid Levels in MELCOR Surry 'TMLB' Calculations with Surge line Break and Air Ingression . . . . . . . . . . . . . . . . .

4.2 Ring 1, Level 7 Clad Temperatures in MELCOR Surry 'TMLB' Calculations

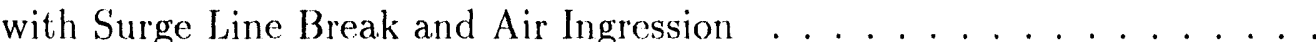

4.3 Core Ring 1 Fuel/Clad Component Materials at Vessel Failure in MELCOR. Surry TMLB' Calculations with Surge Line Failure and Air Ingression . .

4.4 Core Ring 2 Fuel/Clad Component Materials at Vessel Failure in MELCOR Surry TMLB' Calculations with Surge Line Failure and Air Ingression . .

4.5 Core Ring 3 Fuel/Clad Component Materials at Vessel Failure in MELCCOR Surry TMI,B' Calculations with Surge Line Failure and Air Ingression . .

4.6 Core Ring 1 Particulate Debris Component Materials at Vessel Failure in MELCOR Surry TMLB' Calculations with Surge Line Failure and Air In-

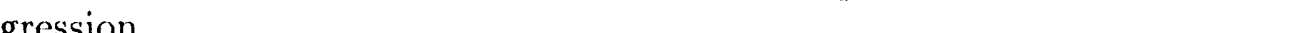

4.7 Core Ring 2 Particulate Debris Component Matcrials at Vessel Failure in MELCOR Surry 'TMLB' Calculations with Surge Line Failure and Air In-

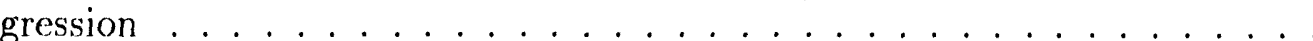

4.8 Core Ring 3 Particulate Debris Component Materials at Vessel Failure in MELCOR Surry TMI_B' Calculations with Surge Line Failure and Air In-

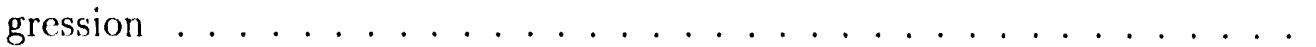

4.9 Core Ring 1 Other Structure Component Materials at Vessel Failure in MELCOR Surry 'TMIB' Calculations with Surge Line Failure and Air In-

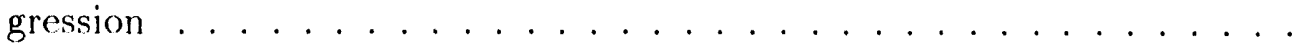

4.10 Core Ring 2 Other Structure Component Materials at Vessel Failure in MELCOR Surry TMLB' Calculations with Surge Line Failure and Air In-

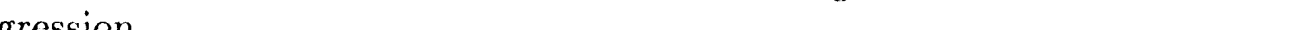

4.11 Core Ring 3 Other Structure Component Materials at Vessel Failure in MELCOR Surry 'TMLB' Calculations with Surge Line Failure and Air In-

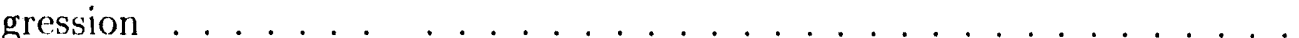

4.12 Ring 3, Level 9 Clad Temperatures in MELCOR Surry TMLB' Calculations with Surge Line Break and Air Ingression . . . . . . . . . . . 
4.13 Core Active Fuel Region Steam Mole Fractions in MELCOR Surry TMLB' Calculations with Surge Line Break and Air Ingression . . . . . . . . 51

4.14 Core Active Fuel Region Nitrogen Mole Fractions in MELCOR Surry TMLB' Calculations with Surge Line Break and Air Ingression . . . . . . . . 52

4.15 Core Active Fucl Region Oxygen Mole Fractions in MELCOR Surry TMLB' Calculations with Surge Line Break and Air Ingression . . . . . . . . 53

4.16 Core Active Fuel Region Hydrogen Mole Fractions in MELCOR Surry TMLIB' Calculations with Surge Line Break and Air Ingression . . . . . 54

4.17 Total Core Masses in MELCOR Surry 'J'MLI3' Calculations with Surge Line Break and Air Ingression . . . . . . . . . . . . . 56

4.18 Core Zircaloy Masses in MELCOR Surry 'TMLB' Calculations with Surge

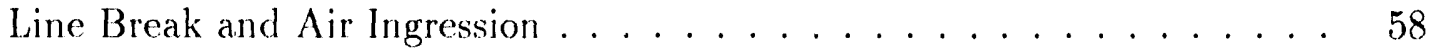

4.19 Core Zirconium Oxide Masses in MELCOR Surry TMLB' Calculations with Surge Line Break and Air Ingression _ . . . . . . . . . . . 59

4.20 Core Stcel Masses in MELCOR Surry TMLB' Calculations with Surge Line Break and Air Ingression . . . . . . . . . . . . . . .

4.21 Core Steel Oxide Masses in MELCOR Surry TMLB' Calculations with Surge Line Break and Air lngressicn _ . . . . . . . . . . . . 61

5.1 Level 9 Clad 'Jemperatures for Grand Gulf Low-Power/Shutdown Calculations with Air Ingression . . . . . . . . . . . . . 


\section{List of Tables}

3.1 Core State at Vessel Failure in MEICOR Surry Midloop Calculations with Air Ingression . . . . . . . . . . . . . . . . 8

3.2 In-Vessel Ruthenium Release in MELCOR Surry Midloop Calculations with Air Ingression . . . . . . . . . . . . . . . . . . . . . . . . 32

3.3 In-Vessel Oxidation in MELCOR Surry Midloop Calculations with Air In-

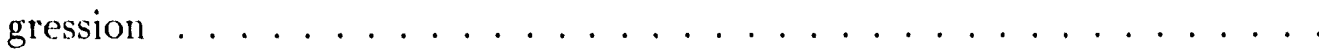

3.4 In-Vessel Radionuclide Release in MELCOR Surry Midloop Calculations with Air Ingression . . . . . . . . . . . . . . . . . . . . . 34

4.1 Core State at Vessel Failure in MELCOR Surry TMLB' Calculations with Surge Line Failure and Air Ingression . . . . . . . . . . . . . .

4.2 In-Vessel Ruthenium Release in MELCOR Surry 'TMLB' Calculations with Surge Line Break and Air Ingression . . . . . . . . . . . . . . . . 62

4.3 In-Vessel Oxidation in MELCOR Surry 'TMLB' Calculations with Surge Line Break and Air Ingression . . . . . . . . . . . . . . .

4.4 In-Vessel Radionuclide Release in MELCOR Surry TMLB' Calculations with Surge Line Break and Air Ingres ion . . . . . . . . . . . . 62

5.1 Oxidation Masses for Grand Gulf Low-Power/Shutdown Calculations with Air Ingression . . . . . . . . . . . . . . . . . . .

5.2 Fission Product Release Masses for Grand Gulf Low-Power/Shutdown Calculations with Air Ingression . . . . . . . . . . . . . 


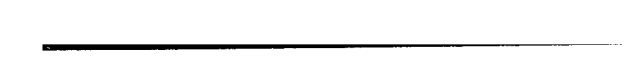

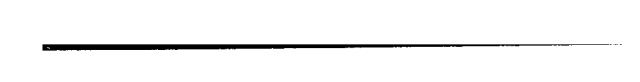

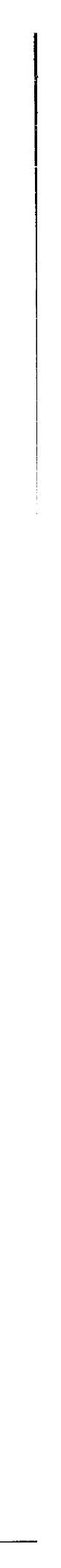




\section{Introduction}

Most modelling of core degradation during severe nuclear reactor accidents has considered only steam oxidation of metals (Zircaloy, stainless steel and Inconel) in the core. There are, however, opportunities for air also to enter the core and oxidize metals. Air oxidation is quite clearly possible in accidents under shutdown conditions when the reactor coolant system is open to the containment atmosphere. Air ingression into the reactor vessel also may occur during operational accidents once some portion of the degrading core penetrates the reactor vessel. A natural circulation of air shrough the reactor core can develop if there are breaks in the reactor coolant system as well as the vessel. [1]

The effects of air on the course of core degradation have not been extensively studied. It is known that the air oxidation of zirconium cladding on the fuel obeys different kinetics than does steam oxidation [2]. The reaction of oxygen with zirconium yiclds about $85 \%$ more heat than does steam oxidation. Given the important role chemically-generated heat plays in the progression of core damage in an accident, the ingression of air might be expected to profoundly accelerate core degradation.

Canadian researchers [3,4] and others [5] have shown that air can greatly enhance the release of radioactive ruthenium from fucl. In the absence of strong oxidants like air, ruthenium is usually predicted to be released to a very small ( $\ll 1 \%)$ extent in reactor accidents $[6,7]$. Experimental studies have shown that in air there is essentially quantitative, significant release of ruthenium from hot ficl. These experimental studies, however, have not considered competitive processes. Clad oxidation might consume oxygen from the air before it could react with the fuel. Or, clad oxidation could cause such rapid heating of the core that there would be little time for ruthenium relcase to take place before the core slumped into the lower plenum of the reactor vessel.

To explore the system-wide implications of air ingression during severe reactor accidents, two series of reactor accident calculations have been conducted using the MEL(COR computer code [8]. These calculations have been of limited scope, to assess the magnitude of air ingression that would be necessary to produce any significant alteration of core degradation or radionuclide release. These calculations constitute initial steps toward the definition of experimental conditions that might be employed in the planned fifth test of the Phebus-FP program [9] which is to involve air ingression [10]. Because so little is known about air oxidation during severe reactor accidents, only limited modifications to the MELCOR code could be made to treat the effects of air ingression. The changes in reaction kinetics of air and Zircaloy, and the enhanced heat of Zircaloy-air reaction, were available in the standard MEICCOR 1.8.2 code version. Modifications made for these calculations treated only the enhanced release of ruthenium from fuel in air; effects air could have on the release and transport characteristics of other radionuclides were not modelled for these initial calculations. 
Section 2 briefly describes the models in the MELCOR code of particular application for these air-ingression analyses.

Section 3 presents results from a set of calculations studying the effect of various amounts of air ingression into the core region during core degradation, beginning immediately after vessel breach, in the Surry PWR for a station blackout accident under mid-loop operation (i.e., plant operational states in which the reactor coolant system level is lowered to the mid-plane of the hot leg) during refueling outages at low-power and shutdown conditions. Section 4 gives results from a set of MELCOR calculations examining the impact from interaction of air with residual fuel following vessel rupture in the Surry PWR for a station blackout at full power in which a surge line rupture has occurred during the in-core damage phase of the accident.

Section 5 describes results from calculations done to address concerns about air oxidation and the associated enhanced release of ruthenium expected to occur when irradiated reactor fuel is heated in air; those calculations were done as part of a separate, ongoing program providing MELCOR support calculations for the Grand Gulf low-power/shutdown PRA [1i]. While these Grand Gulf MELCOR calculations were not done as part of the air ingression analysis effort reported on in this report, thev investigated the same issues and evaluated the same accident consequences, and came to the same basic conclusions. Because those calculations will not be formally documented until the completion of that PRA program, the NRC contract monitor for that program has graciously agreed to allow us to include a brief summary of those calculations and results in this report.

Section 6 summarizes the conclusions of these various air-ingression studies. 


\section{MELCOR Code and Models}

MELCOR [8] is a fully integrated, enginecring-level computer code which is being developed at Sandia National laboratories for the U. S. Nuclear Regulatory ('ommission (USNRC). The progression of severe accidents in light water reactor (LWR) nuclear power plants, including reactor coolant system and containment thermal/hydranlic response, core heatup, degradation and relocation, and fission product release and transport, is treated in MELCOR in a unified framework for both boiling water reactors (B3WRs) and pressurized water reactors (PWRs). The MELC 'OR computer code has been developed to the point that it is now being successfully applied in severe accident analyses, particularly in probabilistic risk assessmont. (PRA) studies (c.g., [6]).

The MELCOR code does not currently include all the phenomenological models that would be needed to calculate the potential for, and magnitude of, air ingression into the vessel and core region during various accident scenarios. A model for in-vessel natural circulation would be needed to model air ingression during refueling or other shutdown accidents, to calculate hot steam upflow from the core to the upper plenum, probably in the center of the core, and simultaneous downflow of air from the upper plenum into the core region, probably arouml the periphery of the core region. Such a model is currently under development, but is not yot ready for use. $\Lambda$ similar model is needed to predict air ingression in accidents such as the station blackout with surge line break; while MELCOR can calculate the inflow of gases from the (avity up though the core and out the surge line break in such a situation, it predicts little or no oxygen present in the cavity source region during this period as the original cavity atmosphere is all displaced hy steam and noncondensables generated in core-concrete interactions. Wither a specific code model for single-phase countercurrent flow or a noding with multiple subdivided flow paths with different clevation differences, flow areas and loss cocfficients would be needed to calculate hot cavity gases flowing up into the dome (or out into the basement) simultancously with colder containment atmosphere flowing down into the cavity; that noding modification was not tried for the calculations in this study.

However, MEL, (OR does include those models needed to calculate the consecpuences of various amounts of air ingression, if the air ingression is assumed and sperified explicitly. In particular, these air-ingression calculations recuire models for the oxidation of 'bircaloy by air, and for the enhanced release of ruthenium from heated fuct in an air enviromment.

The MELCOR code currently includes models for oxidation of Zircaloy by both $\mathrm{II}_{2} \mathrm{O}$ and $\mathrm{O}_{2}$, and of stecl by steam only, calculated using parabolic kinctics, with appropriate rate constant expressions and limited by gaseous diffusion considerations il necessary [12]. In general, solid-state diffusion of oxygen through an oxide layer to unoxidized metal is represented by the parabolic rate equation

$$
\frac{d\left(W^{2}\right)}{d l}=K\left(T^{\prime}\right)
$$

where $W$ is the mass of metal oxidized per unit surface area and $K(T)$ is a rate constant expressed as an exponential function of surface temperature $T$; for the Zircaloy- ${ }_{2}$ 
reaction, the rate constant is evaluated using constants from [2] to yield

$$
K(T)=50.4 \exp \left(\frac{-14630.0}{T}\right)
$$

For oxidation of Zircaloy in environments containing both $\mathrm{H}_{2} \mathrm{O}$ and $\mathrm{O}_{2}$, the maximum oxidation rate calculated for the two gases is used. There are two options for partitioning the oxidant consumption botween the oxygen and the steam. The default option (used in all these air-ingression calculations) does not permit any consumption of steam until all of the available oxygen has been consumed. This model ij available in the released version of MELCOR 1.8.2.

Three options are currently available in MELCOR [13] for modelling the release of fission products from core materials: the CORSOR, CORSOR-M [14] or CORSOR-Booth [15] models may be specified. For these air-ingression analyses, the fission product release model in MELCOR was recently expanded to include an enhanced ruthenium (Class 6 ) release rate explicitly dependent on the oxygen potential, using as the rate expression

$$
\frac{d F}{d t}=7956 P\left(O_{2}\right)^{1.75} \exp \left[\frac{-17400}{T}\right](1-F) s^{-1}
$$

where $P\left(\mathrm{O}_{2}\right)$ is the oxygen partial pressure in atmospheres [16]. This modification will enhance ruthenium release when air is present, and was used for all the MELCOR anal$y$ ses clone in this air-ingression study. (Note that, if $\mathrm{O}_{2}$ in equilibrium with a mixture of $\mathrm{H}_{2}$ and $\mathrm{H}_{2} \mathrm{O}$ were used in this expression, the release predicted would be similar to that calculated using the standard CORSOR-M expression.) This enhanced ruthenium release model was implemented in the production code with version $1.8 \mathrm{NX}$, and is therefore not available in the released version of MELCOR 1.8.2 (MELCOR 1.8NM). Releases of all other classes were calculated using the standard CORSOR-M coefficients available in the code for in-vessel release, and ex-vessel releases were calculated using the standard VANESA expressions for all radionuclide classes.

Note that one of the sensitivity study calculations described in Section 5 used an alternate form of the Class 6 ruthenium release rate expression (also given in [16]), which is not explicitly dependent on the oxygen potential:

$$
\frac{d F}{d t}=518 \operatorname{crp}\left[\frac{-17400}{T}\right](1-F) s^{-1}
$$




\section{MELCOR Surry Midloop Calculations with Air Ingression}

A set of calculations has been completed studying the effect of various amounts of air ingression into the core region during core degradation, beginning immediately after vessel breach, in the Surry PWR for a station blackout accident under mid-loop operation during low-power and shutdown conditions. The intent of the calculation effort is to scope the effects air intrusion might have on the core degradation and radionuclide release under shutdown conditions.

A mid-loop configuration Surry deck used was obtained from Brian Holmes, BNL [17]. That deck was based upon our Surry 'TMLB' high-pressure short-term station blackout deck [18], but modified by BNL for mid-loop conditions in plant operating state 6 (POS6) as part of a low-power/shutdown PRA study underway at Brookhaven. POS6 is a condition occurring during the early portion of the refueling mode of operation, in which the reactor coolant system level is lowered to the mid-plane of the hot leg during refueling. This state is the PWR analogue of the POS6 configuration modelled for the Grand Gulf low-power and shutdown air ingression analyses discussed in Section 5. The plant configuration during the low-power/shutdown period can vary widely depending on the purpose of the outage. It was assumed that all the loops were isolated and that the safety valves wcre removed for maintenance, which provides a vent path from the reactor coolant system to the containment. Containment spray availability was one of the uncertainty parameters in the PRA study, with no sprays available in the base case. Containment, while "closed" during mid-loop operation at Surry, was assumed to leak during POS6, because a temporary restraining plug in the escape tunnel in the containment equipment hatch has no overpressure capability. $[19,20,21]$

We made two changes to the Surry mid-loop configuration deck as received from BNL: the decay heat was set to 24 hours after shutdown (the carliest the plant could possibly be in POS6), and gravity feed from the refueling water storage tank (RWST) to the cold legs (being evaluated as a long-term cooling mechanism) was set to zero. These changes were made to get to core damage as quickly as possible.

A reference calculation was done with no air ingression forced. A series of additional calculations was done, with various amounts of air ingression. A flow path was defined going from the cortainment dome to the core, and a constant velocity flow was specificd to start immediately at vessel failure. The containment dome was used as the air source volume instead of the cavity because the cavity air was quickly displaced by steam and/or hydrogen, while the containment dome atmosphere remained mostly $\sim 80 \%-\mathrm{N}_{2} / \sim 20 \%$ $\mathrm{O}_{2}$ with less dilution by steam, hydrogen and other noncondensables generated by corcconcrete interaction. The velocity needed to obtain desired molar flows was estimated based upon STP conditions, nt t adjusted for containment pressurization; since the air ingression considered covered many orders of magnitude, the $\sim 20 \%$ increase betwen the actual flow obtained using a velocity estimated based on STP conditions and the desired air flow was considered negligible. 
The MELCOR Surry core model [18] consists of 39 core cells divided into 3 radial rings and 13 axial levels; Figure 3.1 illustrates the reactor core nodalization used. Axial levels 4 through 13 make up the active core region, while levels 1 through 3 model the lower plenum, including the core support plate in level 3. Equal-height axial levels were used in the active fucl region, above the core support plate. The three radial rings were not equally subdivided in either radius or area; the innermost, high-powered ring includes $\sim 15 \%$ of the core, the middle ring contains $\sim 60 \%$ of the core, and the outermost, low-power ring includes the remaining $\sim 25 \%$ of the core.

Table 3.1 summarizes the state of the various materials in the core active fuel region, core plate and lower plenum at the time a lower head penetration first fails (i.e., at vessel breach); this state is common to all the air ingression sensitivity study calculations done, because the air ingression is specified to start at vessel breach. Masses of intact components and of debris components are given for each region, together with average temperatures for the debris in the lower plenum, and fractions of Zircaloy and steel oxidized by the time of vessel breach. The fraction of debris molten in each region is estimated from the average debris temperature, which in this case resulted in assuming that Zircaloy, steel, steel oxide and control rod poison in the active fuel region and lower plenum debris are molten and that $\mathrm{UO}_{2}$ and $\mathrm{ZrO}_{2}$ in the debris are solid (i.e., neglecting eutectics mixtures; this assumption is forced by the MELCOR output available to the analyst). Also given is the fraction of material relocated. This is generally larger than the fraction molten bccause material can melt and relocatc, and then subsequently refreeze or quench; also, $\mathrm{UO}_{2}$ fuel usually relocates as a solid, after clad collapse but before fuel melt.

The various materials in the MELCOR "fuel/clad" component just prior to vessel failure, both any intact materials remaining in their original position and candled, refrozen conglomerate debris materials, are shown in Figures 3.2 through 3.4 for the three radial rings in the MELCOR Surry core model. Figures 3.5 through 3.7 show the materials calculated to be in the "particulate debris" component in the three core rings at the same time, while the various materials in the MELCOR "other-structure" component just prior to vessel failure, both any intact materials remaining in their original position and candled, refrozen conglomerate debris materials, are shown in Figures 3.8 through 3.10 for the three core rings in the MELCOR Surry core model. (Refer to [8] for an explanation of these MELCOR components, if necessary.) The "elevation" used as the ordinate in Figures 3.2 through 3.10 is the same as the core level elevations shown in Figure 3.1 , with the core support plate at $\geq 3 \mathrm{~m}$, the lower plenum between 0 and $\sim 3 \mathrm{~m}$, and the active fuel region from $\geq 3 \mathrm{~m}$ to $\sim 6.722 \mathrm{~m}$. The fraction of each core cell occupied by any given material is shown. However, recall that the core cells are not equal in the three rings; the innermost, high-powered ring includes $\sim 15 \%$ of the core, the middle ring contains $\sim 60 \%$ of the core, and the outermost, low-power ring includes the remaining $\sim 25 \%$ of the core.

The innermost ring has no intact structure in the active fuel region at all at the time of vessel failure (Figure 3.2), but there is a substantial debris bed both in the lower plenum and in the active fuel region above the core support plate in that first ring (Figure 3.5). 


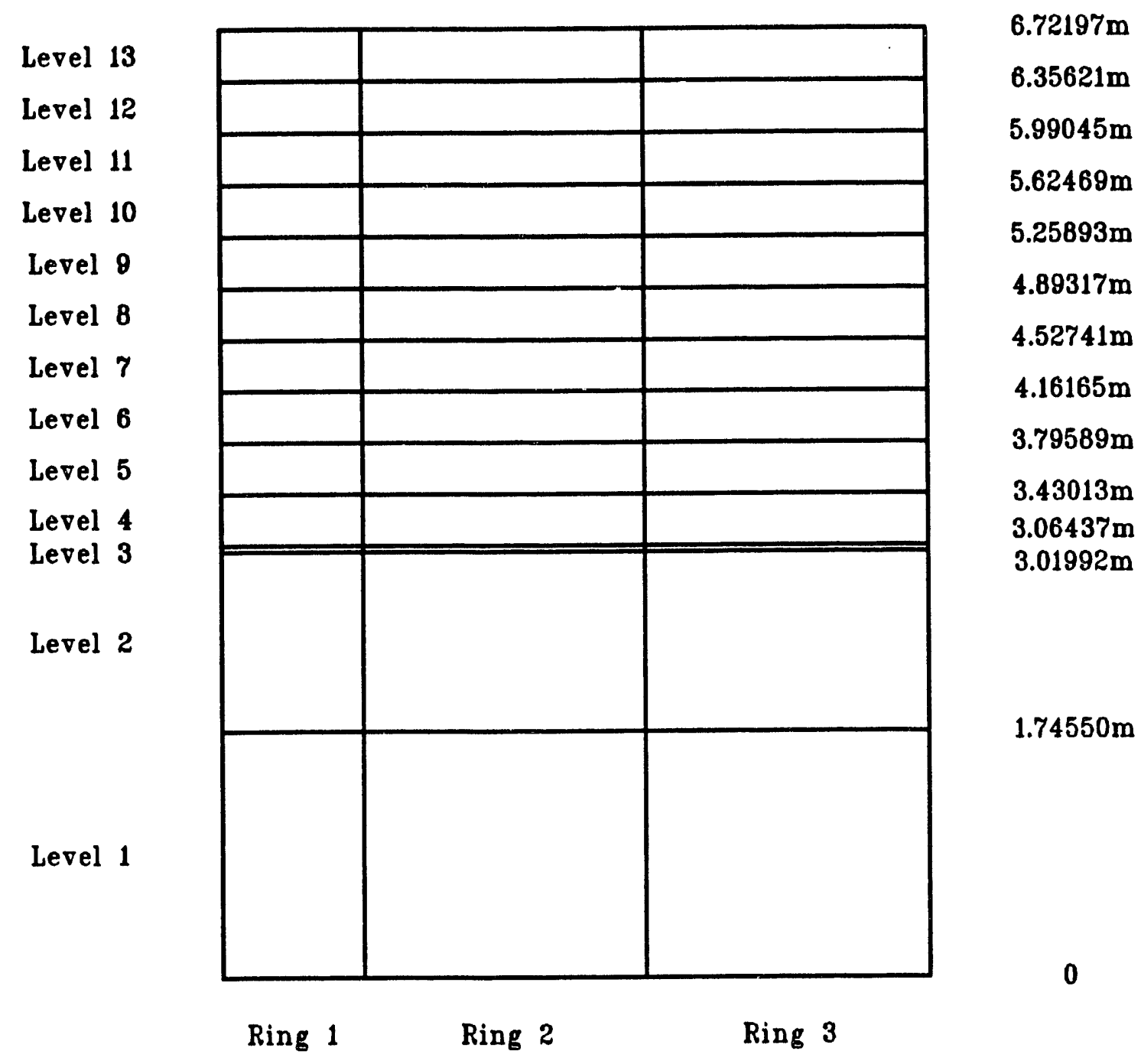

Figure 3.1. Reference MELCOR COR Input Model for Surry Core 
Table 3.1. Core State at Vessel Failure in MELCOR Surry Midloop Calculations with Air Ingression

Active Fuel Region Masses $(\mathrm{kg})$
$\mathrm{UO}_{2}$
Zircaloy
Zirc Oxide
Steel
Steel Oxide
CRP
Total
Core Plate Masses $(\mathrm{kg})$
UO
Zircaloy
Zirc Oxide
Steel
Steel Oxide
CRP
Total
Lower Plenum Masses $(\mathrm{kg})$
UO
Zircaloy
Zirc Oxide
Steel
Steel Oxide
CRP
Total

$$
\text { Intact Debris }
$$$$
14,347 \quad 34,615
$$$$
6,559 \quad 1,947
$$$$
3,096 \quad 835
$$$$
178 \quad 21
$$$$
112 \quad 8
$$$$
808 \quad 1,084
$$$$
25,100 \quad 38,510
$$

$\begin{array}{cc} & 94 \\ & 37 \\ & 13 \\ 225 & 54 \\ & 9 \\ & 15 \\ 225 & 222 \\ & \\ & 31,656 \\ & 3,334 \\ & 1,721 \\ 0 & 87 \\ 0 & 51 \\ & 92 \\ 0 & 36,941\end{array}$

Average Debris Temperature $(\mathrm{K})$

Active Fuel Region

$\sim 2300$

Core Plate

$\sim 1000$

Lower Plenum

$\sim 2350$

Fraction Debris Molten

Active Fuel Region

Core Plate

Lower Plenum

$$
\begin{array}{r}
\sim 8 \% \\
\sim 0 \% \\
\sim 10 \%
\end{array}
$$

Fraction Material Relocated

$\sim 75 \%$

Fraction Oxidized

$$
\begin{array}{cc}
\text { Zircaloy } & \text { Steel } \\
\sim 35.25 \% & \sim 25.67 \%
\end{array}
$$




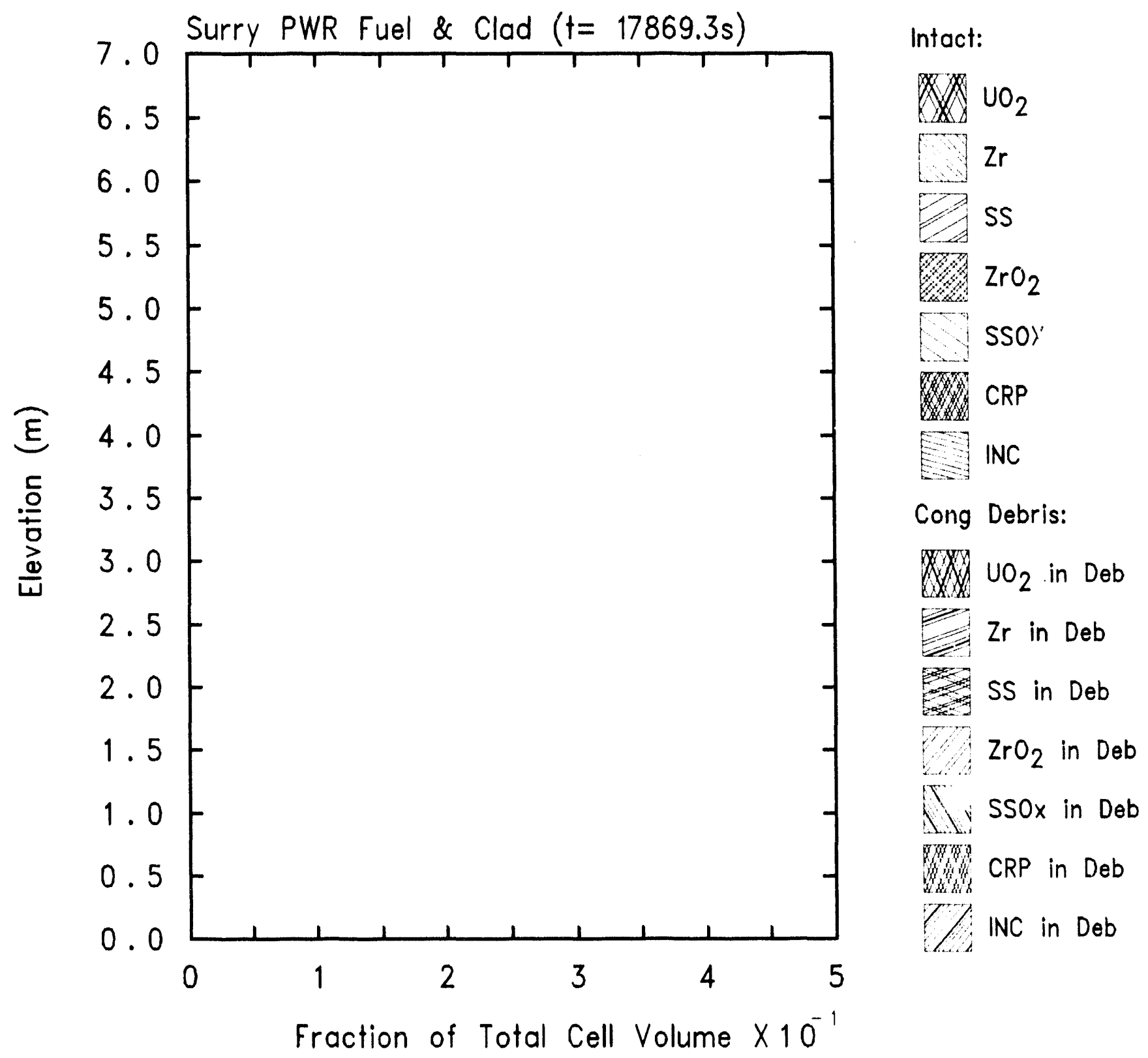

Figure 3.2. Core Ring 1 Fuel/Clad Component Materials at Vessel Failure in MELCOR Surry Midloop ('alculations with Air Ingression 


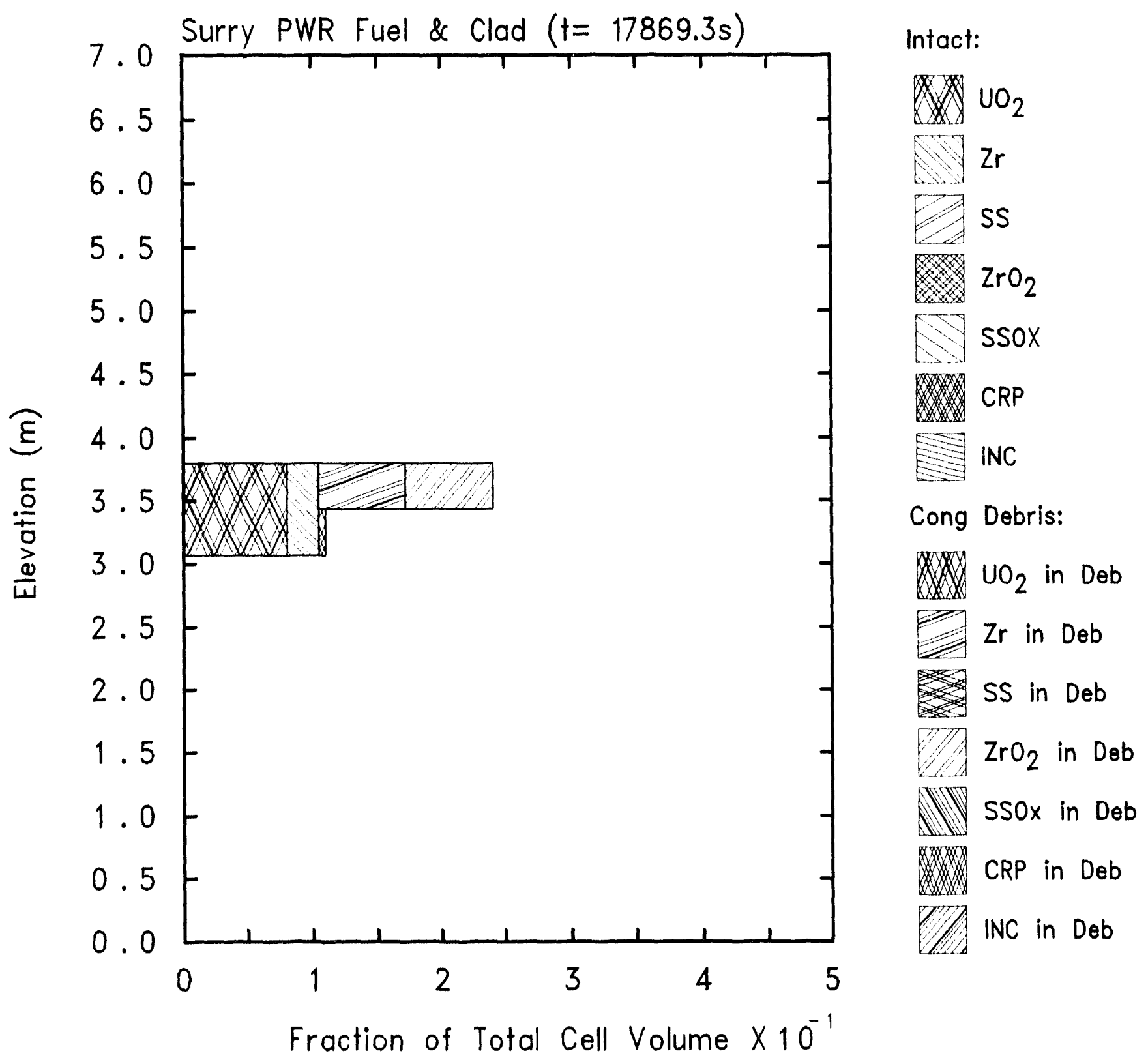

Figure 3.3. Core Ring 2 Fuel/Clad Component Materials at Vessel Failure in MELLOR Surry Midloop Calculations with Air Ingression 


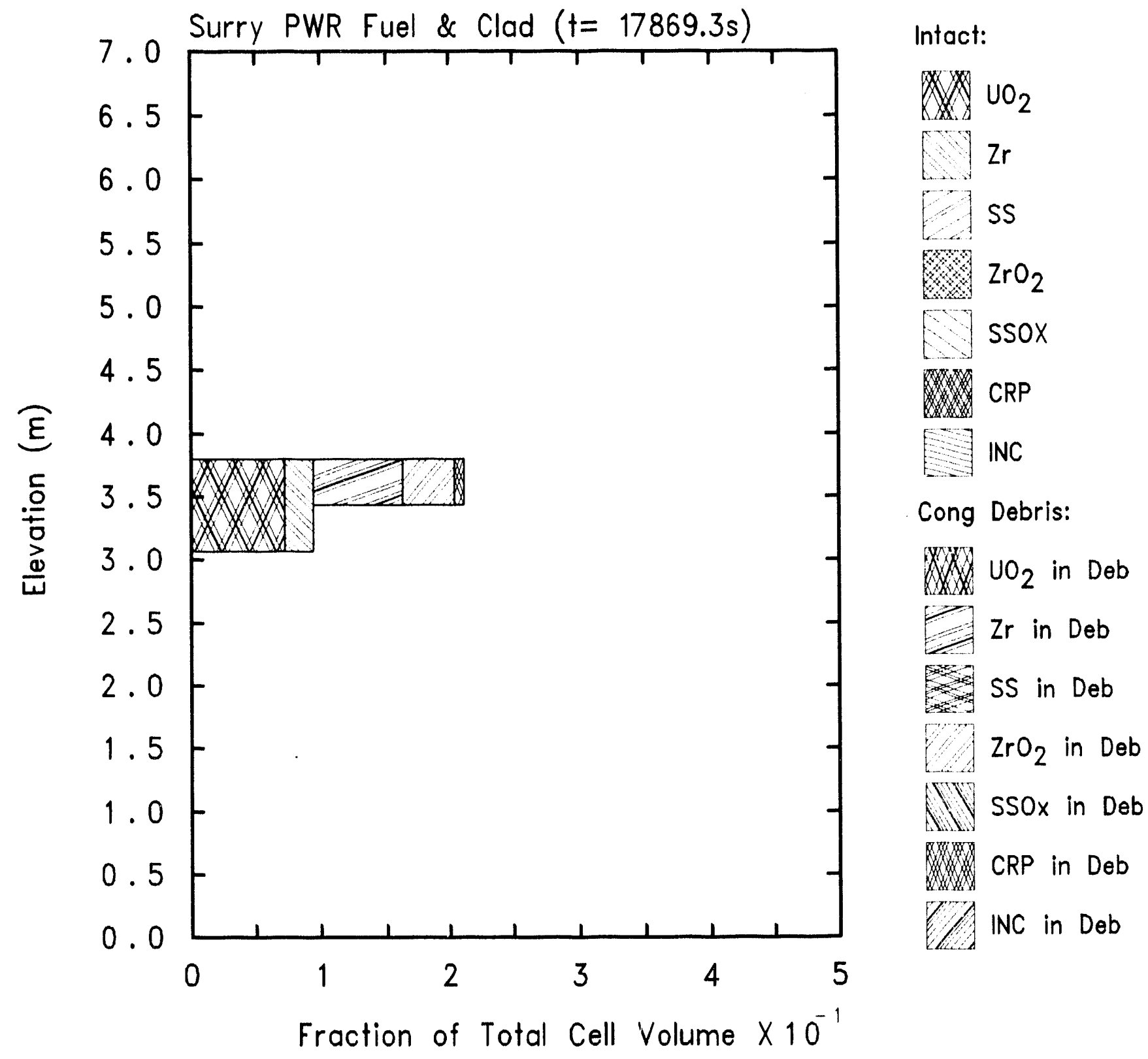

Figure 3.4. Core Ring 3 Fuel/Clad Component Materials at Vessel Failure in MELCOR Surry Midloop Calculations with Air Ingression 


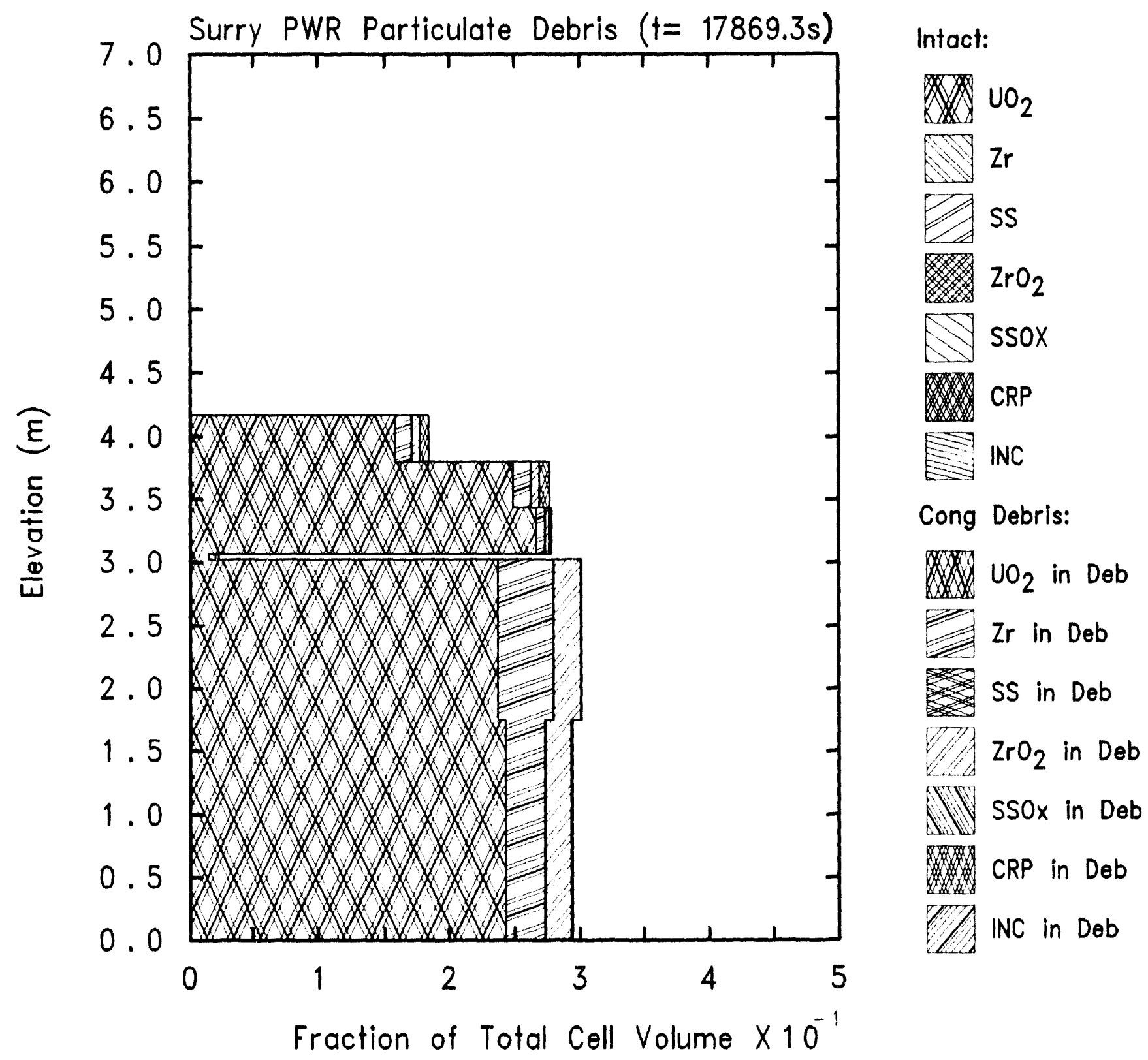

Figure 3.5. Core Ring 1 Particulate Debris Component Materials at Vessel Failure in MELCOR Surry Midloop Calculations with Air Ingression 


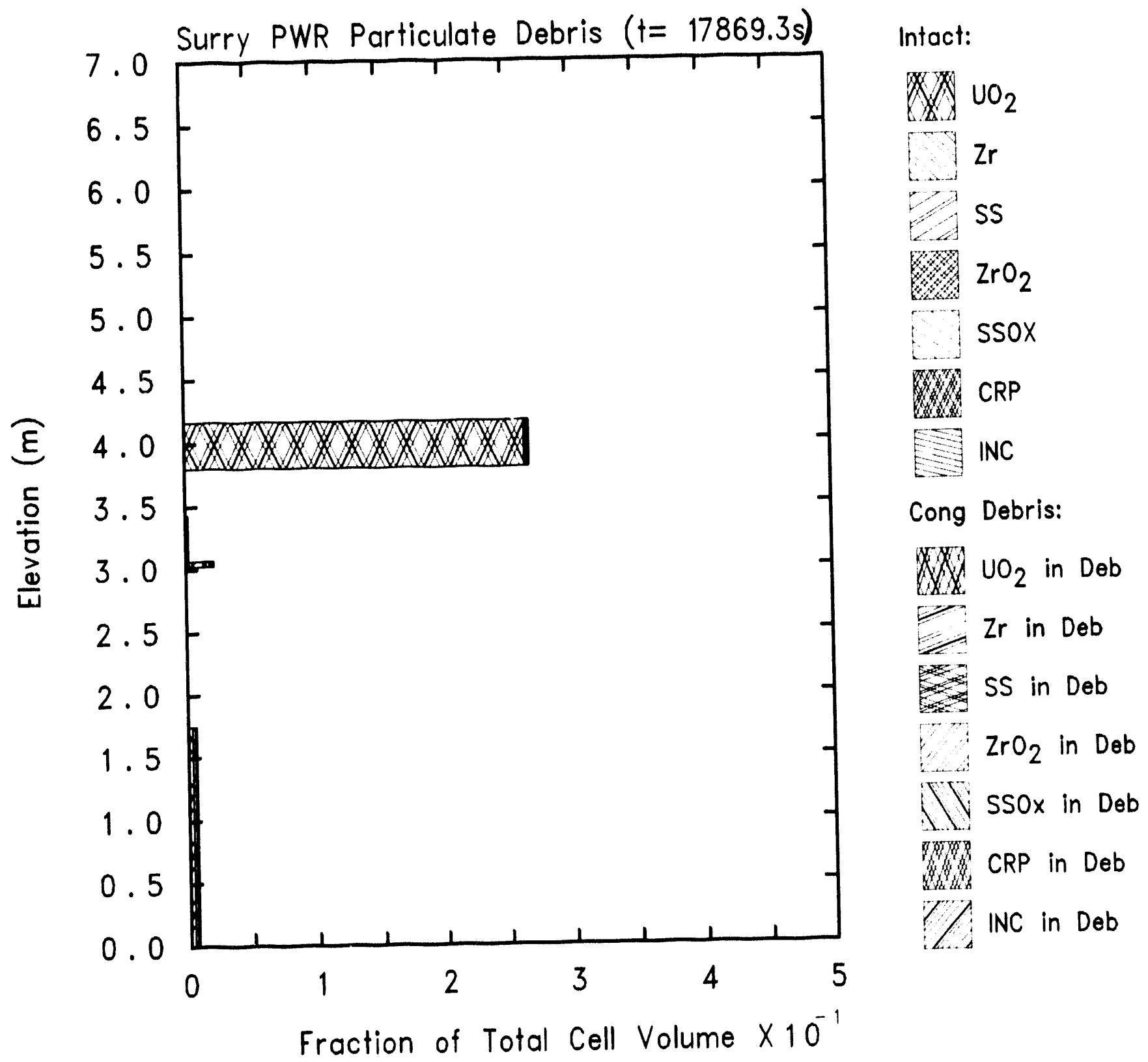

Figure 3.6. Core Ring 2 Particulate Debris Component Materials at Vessel Failure in MELCOR Surry Midloop Calculations with $\mathrm{Air}$ Ingression 
Elevation (m)






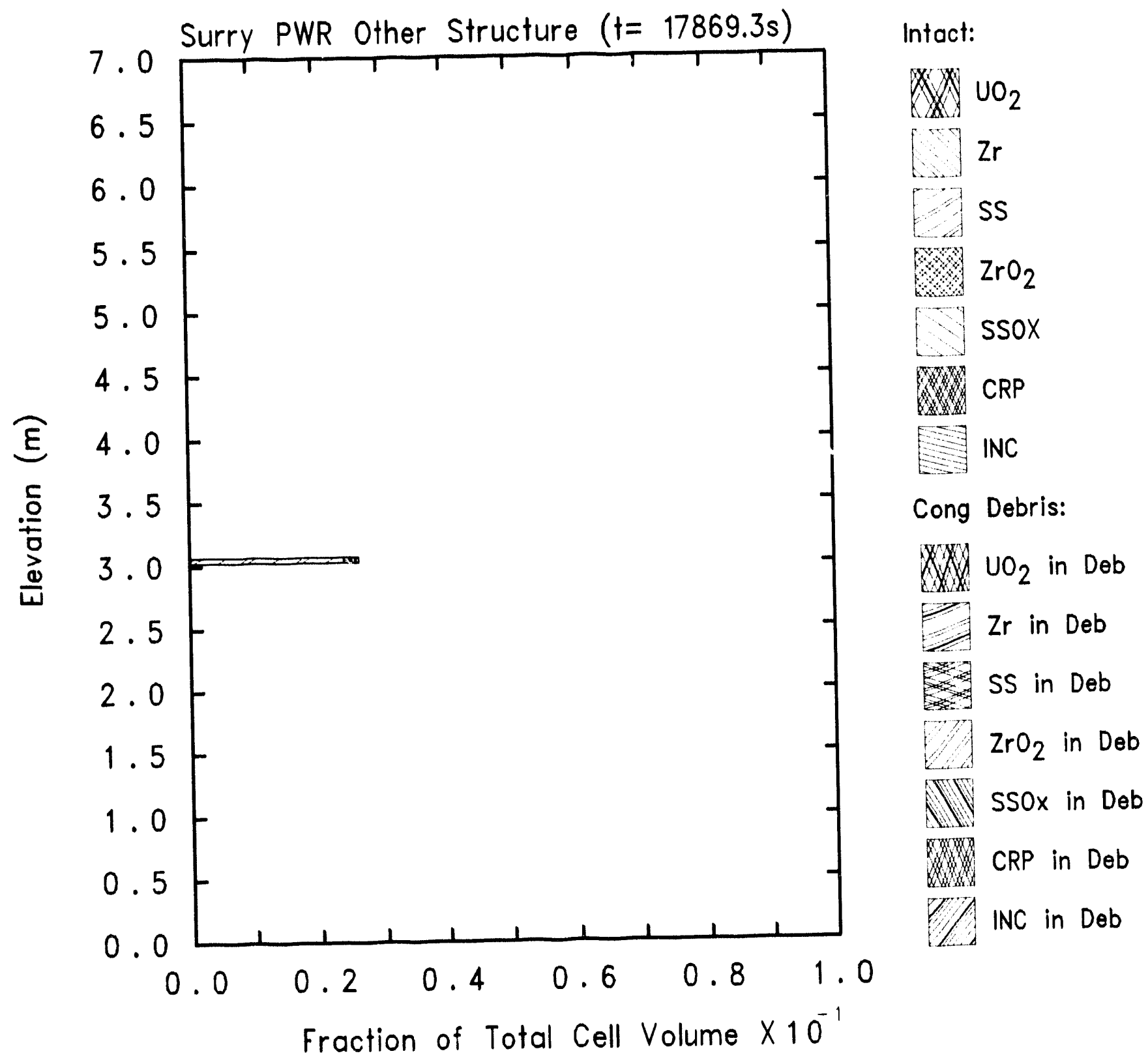

Figure 3.8. Core Ring 1 Other Structure Component Materials at Vessel Failure in MELCOR Surry Midloop Calculations with Air Ingression 




Figure 3.9. Core Ring 2 Other Structure Component Materials at Vessel Failure in MELCOR Surry Midloop Calculations with Air Ingression 


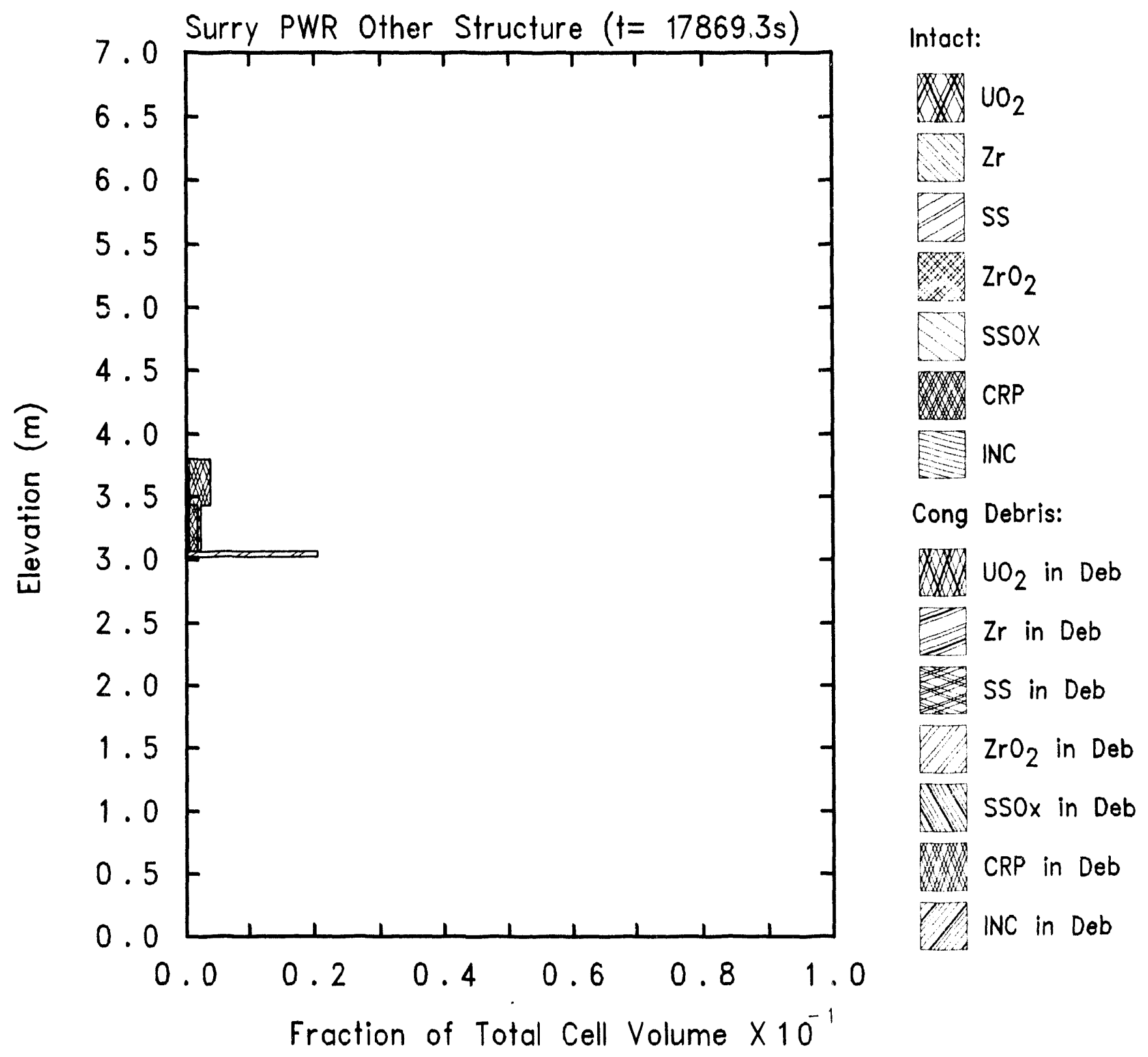

Figure 3.10. Core Ring 3 Other Structure Component Materials at Vessel Failure in MELCOR Surry Midloop Calculations with Air Ingression 
Some intact material remains in the lower core levels in the active fuel region in both the sccond and third rings (Figures 3.3 and 3.4), with those intact materials together with the core plate supporting one or more levels of particulate debris held in the active fuel region in both the second and third rings (Figures 3.6 and 3.7 ). The core plate itself is clearly visible in Figures 3.8 through 3.10 as the very thin structure at $\geq 3 \mathrm{~m}$ elevation; in Figures 3.9 and 3.10 the core plate is seen to be supporting some candled, refrozen other structure. such as control rod poison and the control rod guide tube material. Note that only $355 \%$ of the Zircaloy (and 25-30\% of the stecl) has been oxidized up to this time, cither in the intact clad or in the debris bed: most of the Zircaloy remains unoxidized in hoth the remaining intaet clad and in the debris bed at the time of vessel failure and at the specified start of the assumed air ingression.

Figure 3.11 through 3.1 .4 present the steam, nitrogen, oxygen and hydrogen mole fractions in the core active fuel region contel volume. respectively, resulting from various amount of air ingression. In all cases. prior to vessel breach, the core atmosphere oscillates between mostly steam and mostly hydrogen. After vessel breach, the results with $\simeq 1 \mathrm{~mol} / \mathrm{s}$ air ingression are gencrally similar to the results with no prescribed air ingression: the core atmosphere is mostly steam, with some small amount of $\mathrm{N}_{2}$ and $\mathrm{O}_{2}$ appearing some time after vessel breach. The results with higher air ingression rates $(\simeq 10$ mole/s and $u p)$ are all similar after vessel failure, and qualitatively different from the results with $\simeq 1$ mole/s air ingression and with no prescribed air ingression: the core atmosphere is mostly air. as soon as air ingression is specified to begin, with some small anount $(\leq 20 \%)$ of steam. In all cases. very little $(\leq 5 \%)$ hydrogen is present after vessel rupture.

Mass-weighted average core clad temperatures in these calculations with various air ingression rates are presented in ligure 3.15. In all cases with any amount of air ingression. the average clad femperatures after oxidation rmaway are similar and are visibly higlere than the basecase and alsis with no air ingression: however, in all cases with any amount of air ingression. thre clad subsecunently fails sooner (indicated by the temperature going to zero) than predicted in the basecase analysis with no air ingression. This is because the higher late time temperatures in the tnalyses with air ingression (due to the higher energy of reaction for Zircaloy oxidation with air rather than with steam) cause the core material to mell, relocate and be lost to the cavity sooner than predicted with no air ingression into the core. Figure 3.16 gires the maximum clad temperatures for these Surry midloop calculations. With and withont air ingression, showing that the maximum clad temperature does not increase significantly as the average clad temperature increases: the intart Zircaloy clad always fails and relocates when it reaches its melt point of $209 \mathrm{sk}$. (The intact fuel average and mavimum temperature comparisons are very similar to these intact chad average and maximum temperature comparisons.)

Typical clad temperatures predieted in these alculations are given in Figures 3.17 and 3.18 for cells in the middle core ring. in the lower core active fuel region (about $0.6 \mathrm{~m}$ above the core support plate). and in the upper core active fuel region (about $2.0 \mathrm{~m}$ above the core suppont plate). respertively. The higher elad temperatures after oxidation runaway ith air ingression and air oxidation are clearly visible in the lower core, but 


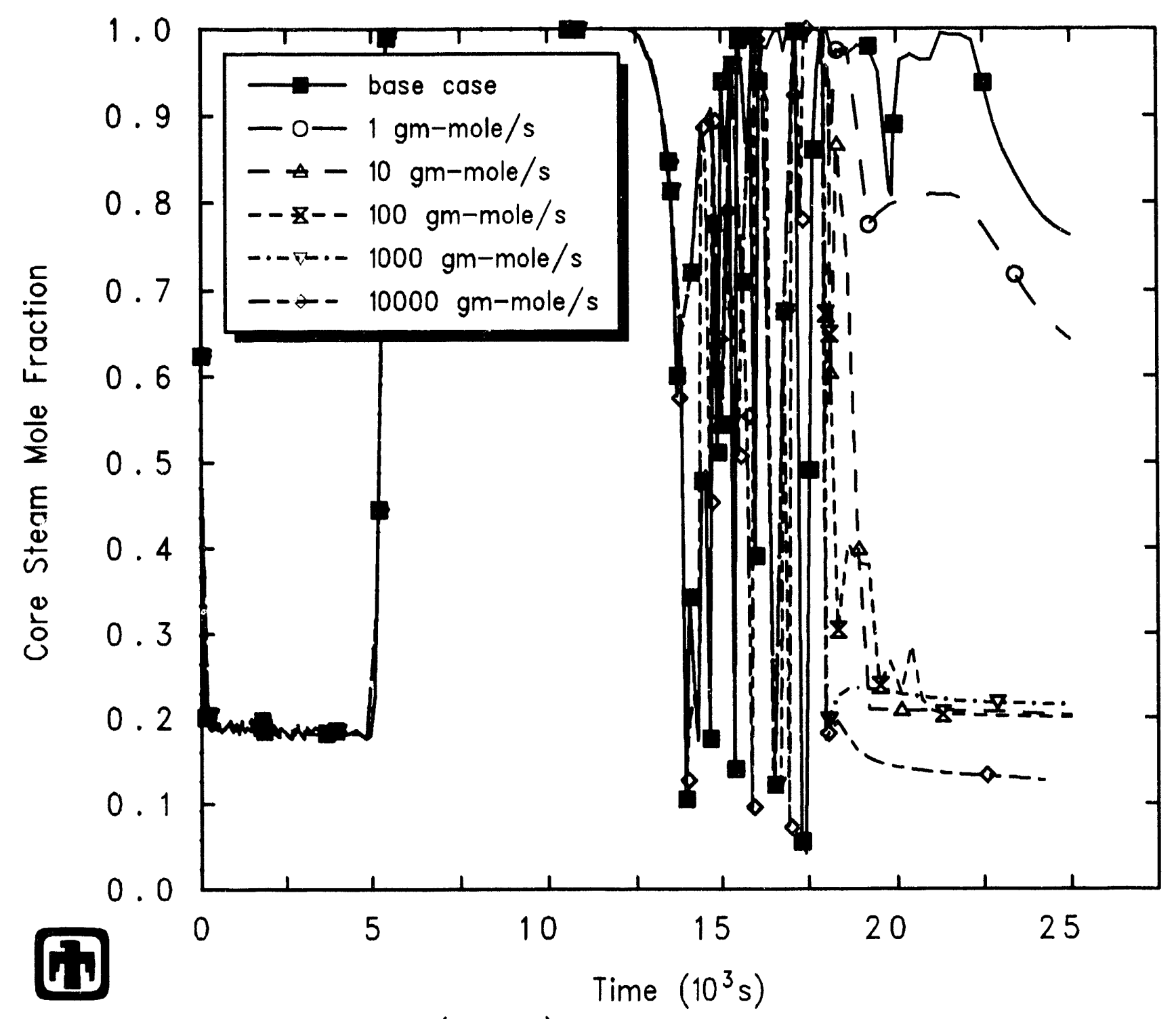

Surry Mid-Loop Operation (POS 6)

IMDNDQINX 9/13/93 13:40:52 MELCOR HP

Figure 3.11. ('ore Active Fuel Region Steam Mole Fractions in MELCOR Surry Midloop ('alculations with Air Ingression 


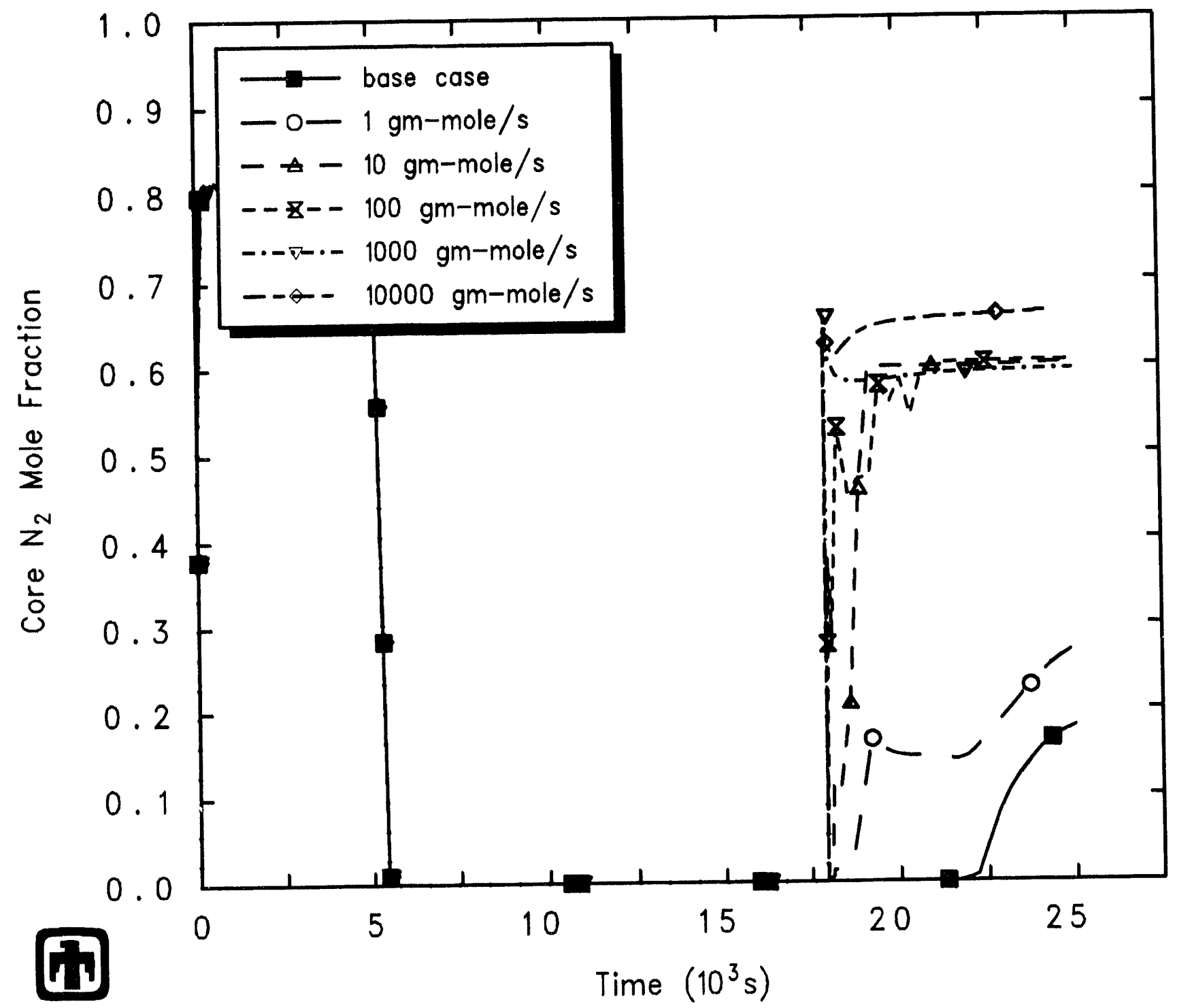

Surry Mid-Loop Operation (POS 6) IMDNDQINX $9 / 13 / 93 \quad 13: 40: 52 \quad$ MELCOR HP

Figure 3.12. Core Active Fuel Region Nitrogen Mole Fractions in MELCCOR Surry Midloop (alculations with Air Ingression 


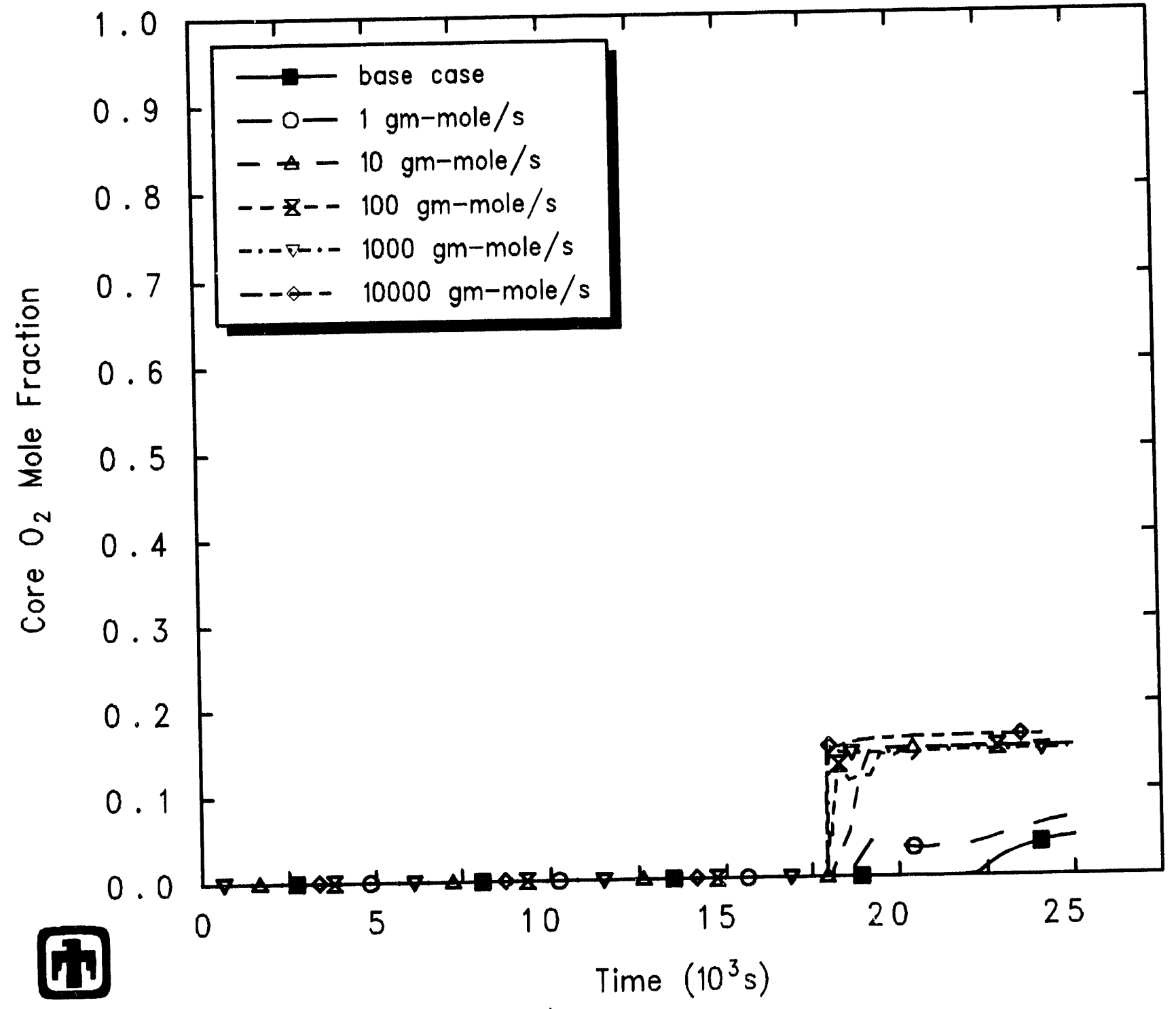

Surry Mid-Loop Operation (POS 6) IMDNDQINX $9 / 13 / 93 \quad 13: 40: 52$ MELCOR HP

Figure 3.13. Core Active Fuel Region Oxygen Mole Fractions in Mlil('OR Surry Midloop Calculations with Air Ingression 


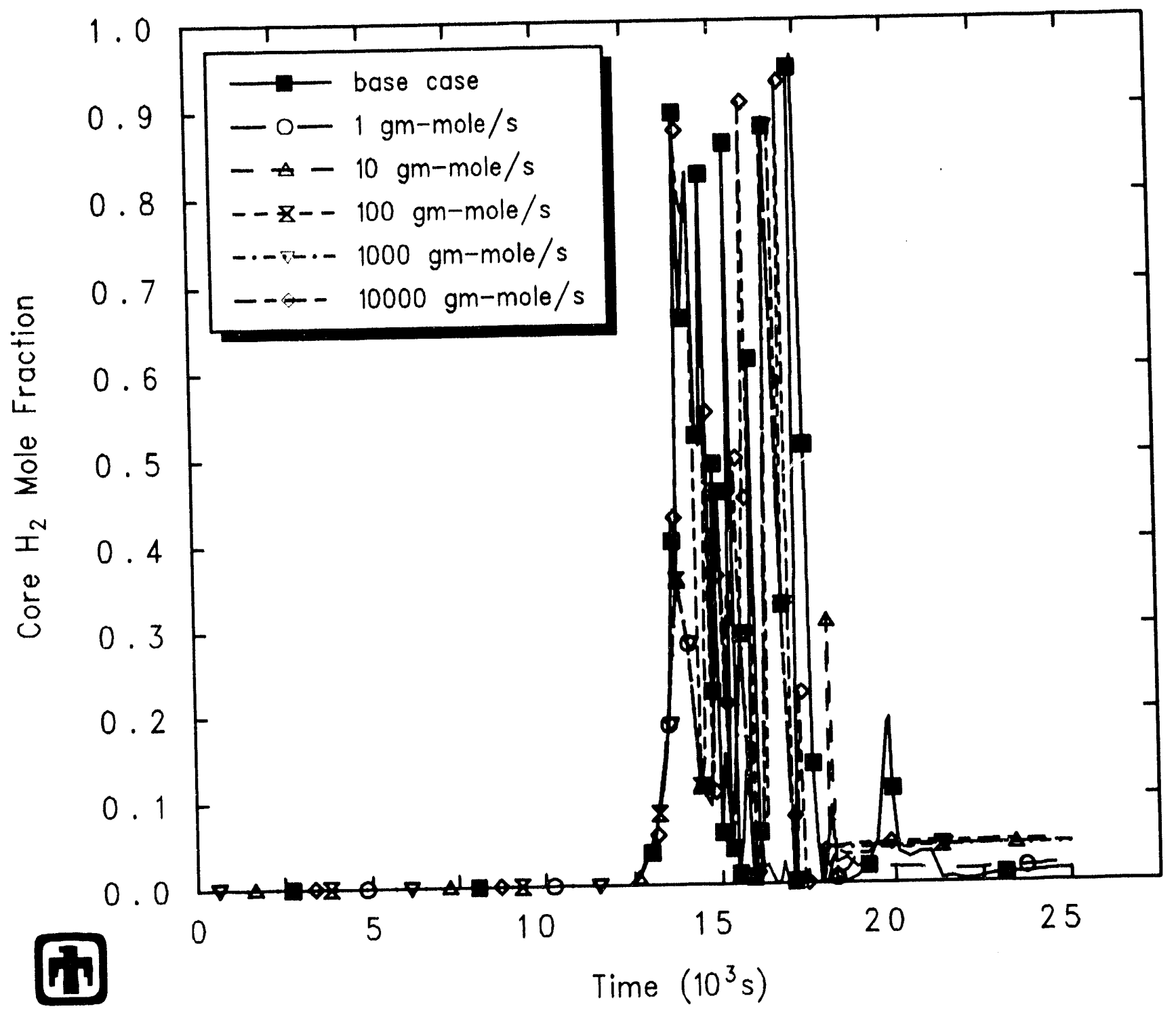

Surry Mid-Loop Operation (POS 6) IMDNDQINX $9 / 13 / 93 \quad 13: 40: 52 \quad$ MELCOR HP

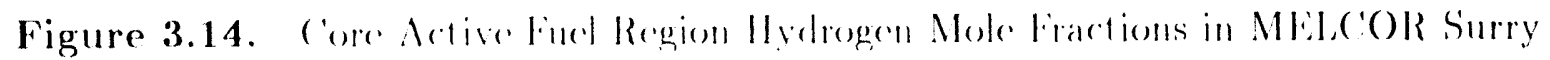
Midloop ('alculations with Sir logression 


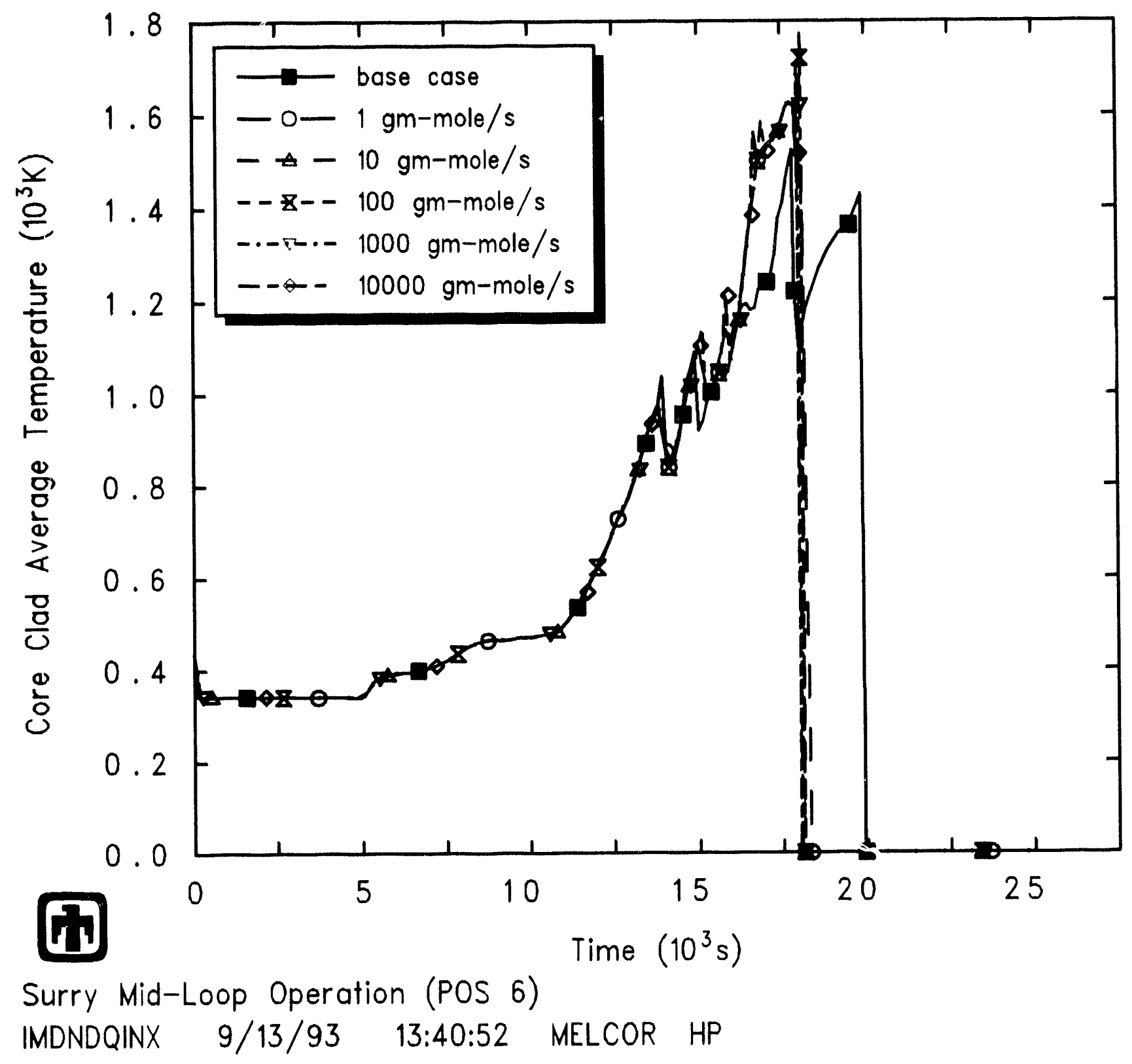

Figure 3.15. ('ore Average ('lad 'Temperatures in Mlil(')R Surry Midloop (alculations with Air Ingression 


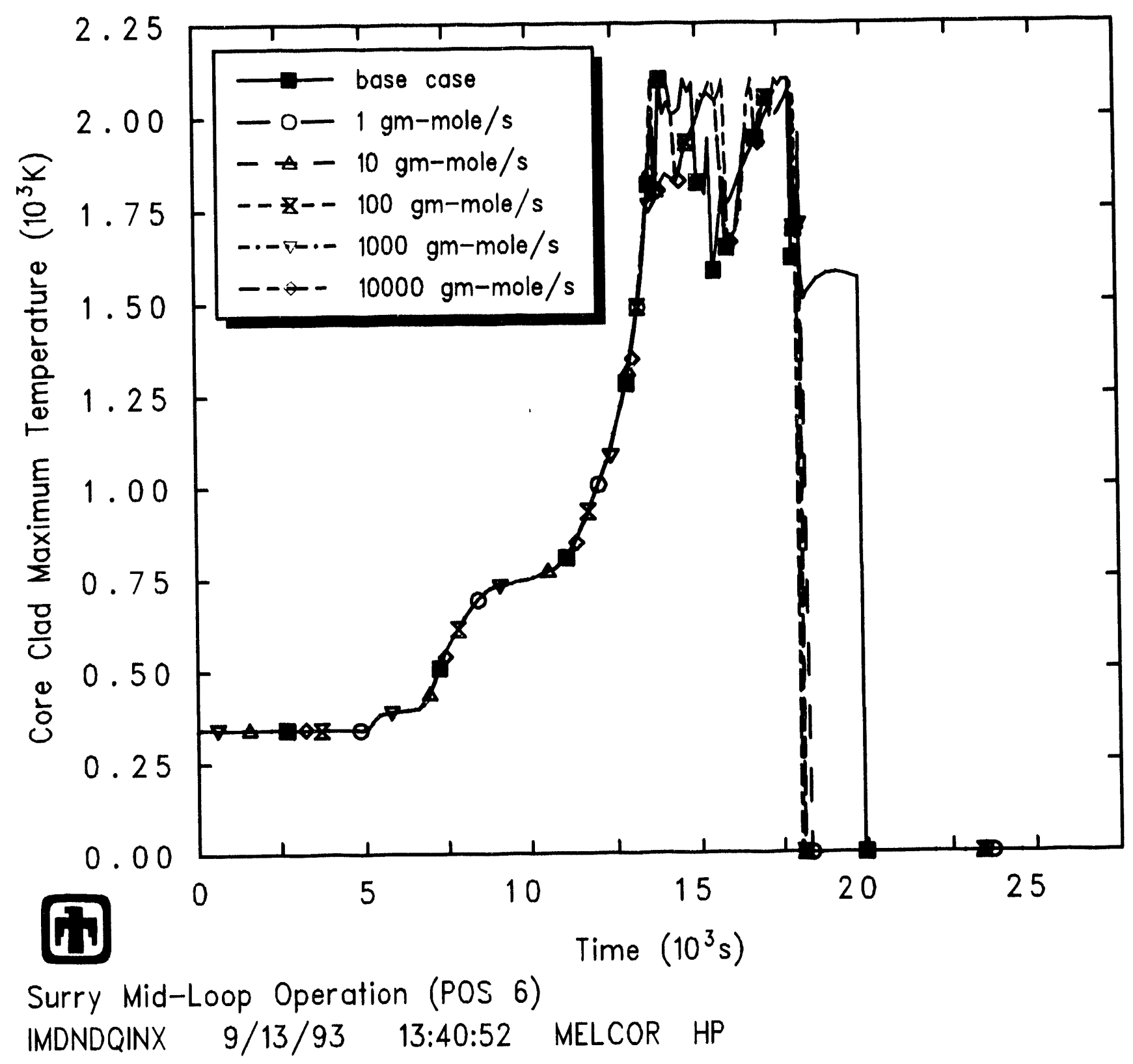

Figure 3.16. Core Maximum (lad T'mperatures in MLLCOR Surry Midloop Calculations with Air Ingression 
almost indistinguishable in the upper core.

Figure 3.19 demonstrates the effect of various amounts of air ingression on the material retention in-vessel es cjection to cavity. All calculations show the same overall behavior, with the majority $(\geq 60 \%)$ of the core material ejected immediately upon vessel failure, and most of the remainder $(\leq 10 \%)$ of the core material lost to the cavity after some small time delay. The slightly higher late-time temperatures in these midloop-aceident. calculations with user-specified air ingression into the core, due to the higher energy of reaction for Zircaloy oxidation with air rather than with steam, canse the remainder of the core material to molt, relocate and be lost to the cavity sooner than predicted in the calculation with no user-specified air ingression into the core.

Mass-weighted average core debris temporatures in fhese calculations with various air ingression rates are presented in Figure 3.20, while Figure 3.21 gives the maximum debris temperatures for these Surry midloop calculations, with and withont air ingression. In all cases with any amount of air ingession, the average debris temperatures between $\sim 15,000 \mathrm{~s}$ and $\sim 17,500 \mathrm{~s}$ are very similar and are slightly lower than in the basecase analysis with no air ingression. After most material has been cjected from the vessel, at $\sim 18,000$ s, both the average and maximmm debris temperatures derease as the air ingression rate increases; with increased air ingression rates, very little debris is left in the vessel and that residual debris is being cooled by the increased amonnts of relatively cold air being sonreed into the core and flowing through the lower plemum and out the vessel breach, as shown in Figure 3.2.2. (Note that Mlide(O) does not calculate any oxidation of $\mathrm{U}\left(\mathrm{O}_{2}\right.$ by air.) Debris temperature comparisons in individual cells closely resemble the average and maximmon temperature comparisons.

Table 3.2 summarizes the in-vessed ruthenimm release fractions, normalized to the initial inventory of class 6 radiomuclides (15)1.1kg in this case). The in-vessel releases are subdivided into releases in the "core" and "lower plemmon" regions. The "core" region is the active fuel region, above the core support plate, and includes releases from both int act fuel and from debris still supported by intact core components or by the core support plate; the "lower plenum" release is from debris that has fallen through the core support plate and is being held in the lower plemum on the vessed lower head prior to bering lost to the cavity through a lower head failure.

With no air ingression, only trace amounts of ruthenimm are released. Note that at $0.032 \mathrm{~kg} / \mathrm{s}$ ( $\simeq 1 \mathrm{~mole} / \mathrm{s}$ ) of air ingression, there is some slight rnhancement of ruthenium release, almost all from debris in the lower plemmm. Relatively small rates of air ingerssion (between $\simeq 1 \mathrm{~mole} / \mathrm{s}$ and $\simeq 10 \mathrm{~mole} / \mathrm{s}$ ) ause a qualitative change in the somere term, with enhanced ruthenium release in the active fuel region dominating release from deteris in the lower plenum. 'There is a significant increase in ruthenium release as the air ingression is increased from $0.32 \mathrm{~kg} / \mathrm{s}(\simeq 10 \mathrm{~mol} / \mathrm{s})$ to $3.2 \mathrm{~kg} / \mathrm{s}(\simeq 100 \mathrm{~m}$ ole $/ \mathrm{s})$, with $\sim 80 \%$ of $1 \mathrm{he}$ release in the core active fuel region and $220 \%$ from debris in the lower plenum. For air ingression rates $32 \mathrm{~kg} / \mathrm{s}(\simeq 1 \mathrm{~kg}$ mole/s), almost all the class (f radionuclide inventory is released in-vessed. These results quantify the amomnt of air ingression that wonld be reguired to signifieantly enhance ruthenium release during the in vessed core damber phase, one major efferet of the air ingression. 


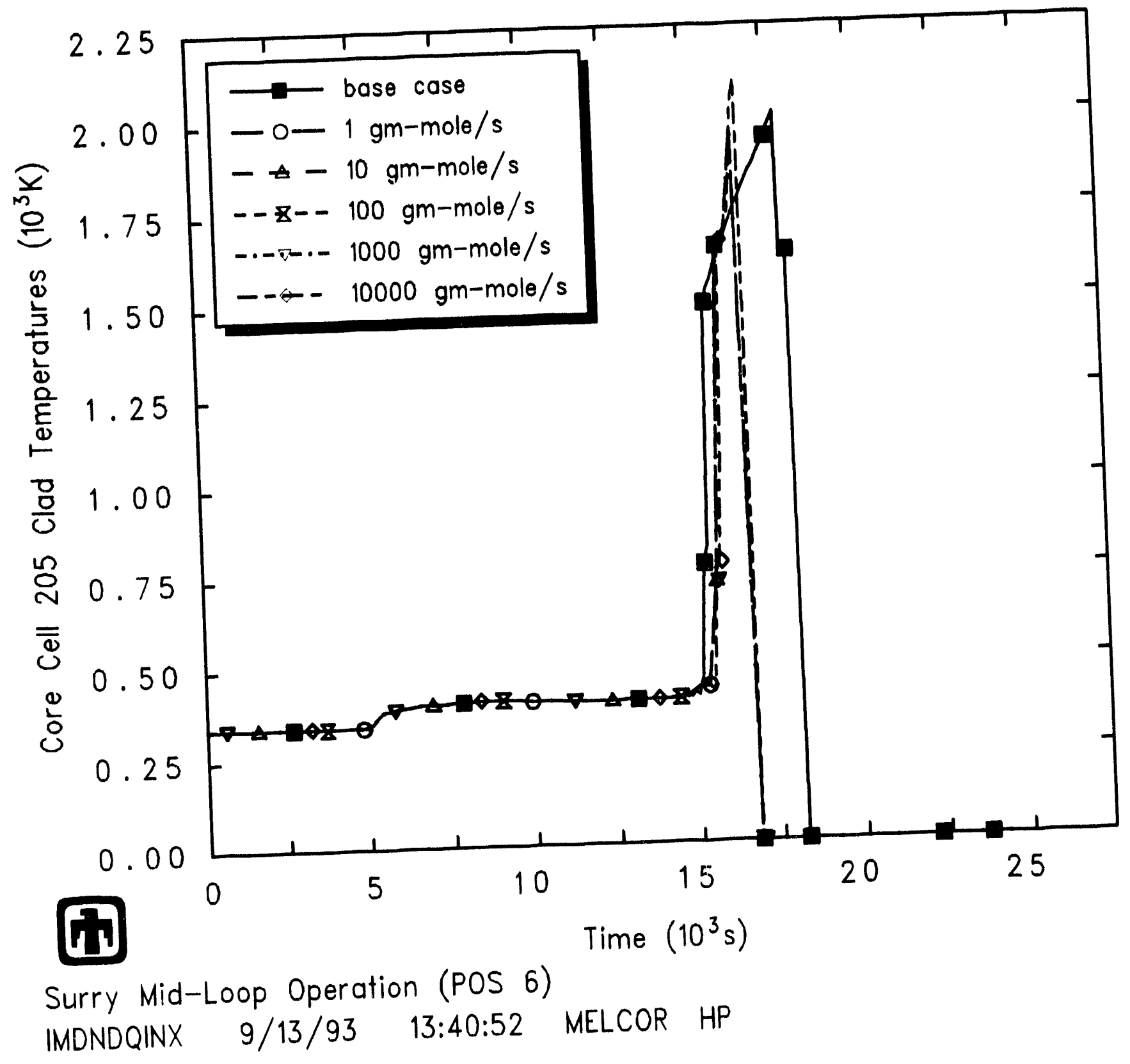

Figure 3.17. ('ore Ring 2. Levels ('lad Temperatures in MELC(OR Surry Midloop ('alculations with Air Ingression 


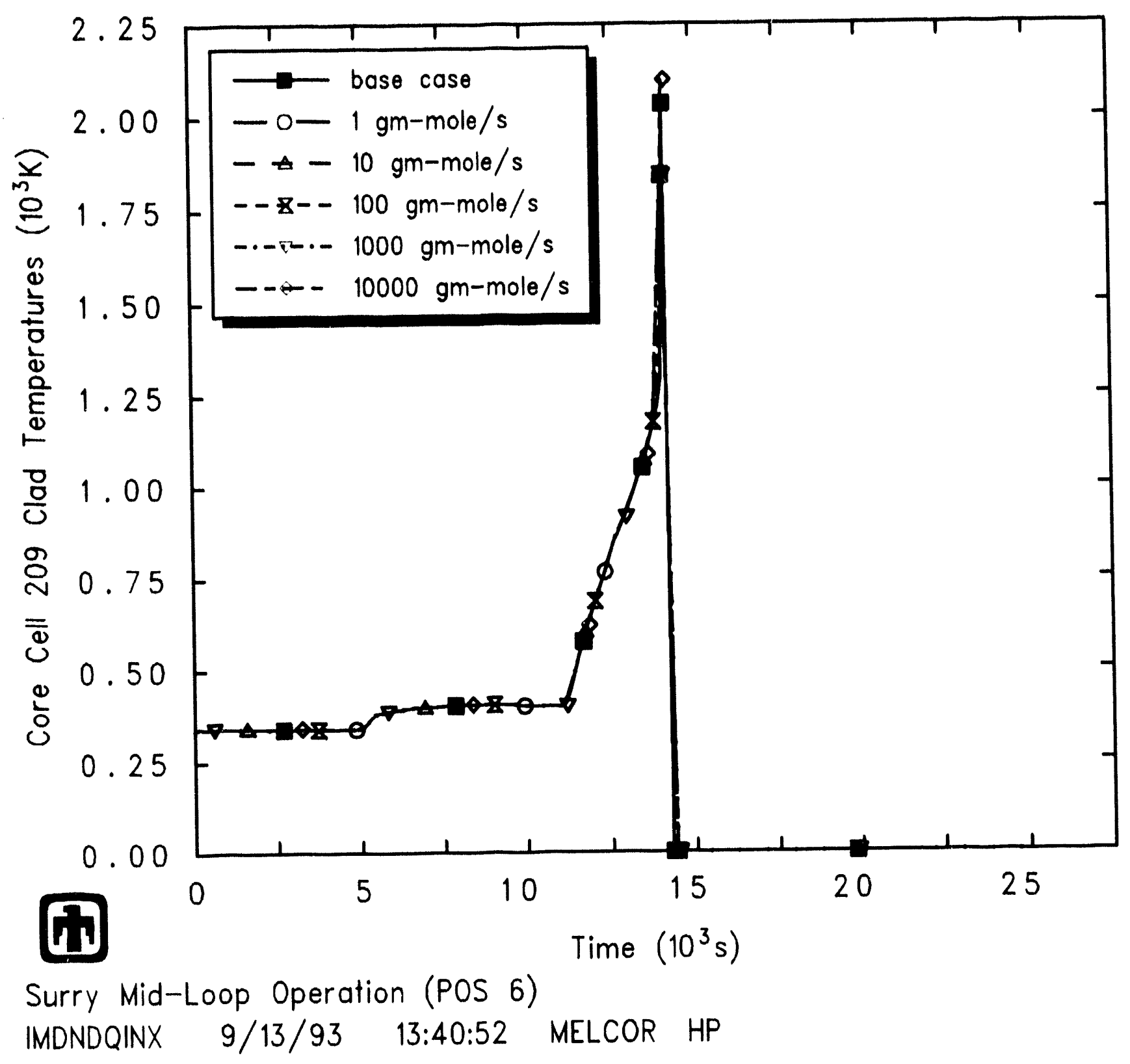

Figure 3.18. ('ore Ring 2, lavel 9) ('lad T'moneratures in MELL(')R Sinry Midloop) ('alculations with Air Ingression 


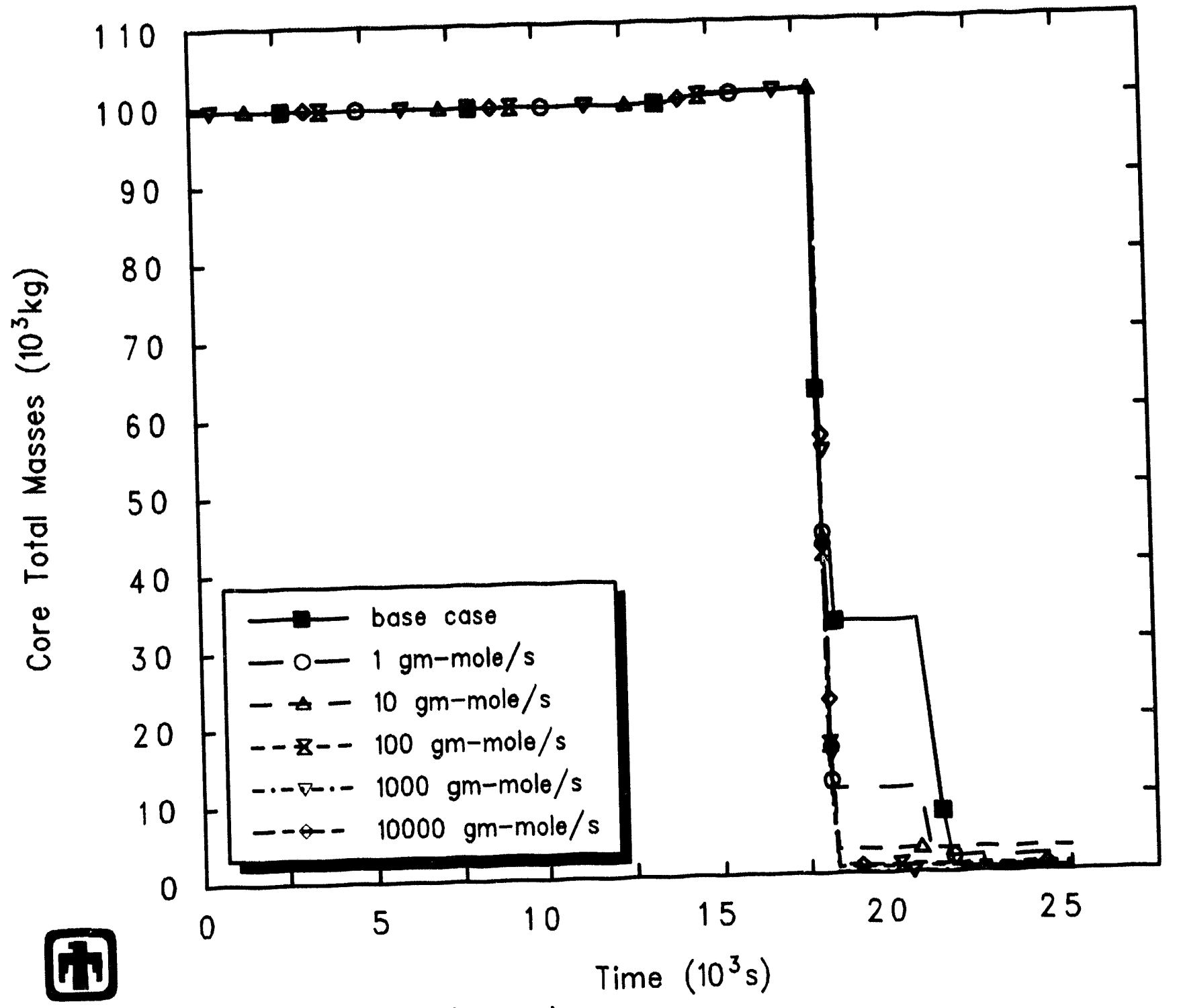

Surry Mid-Loop Operation (POS 6) IMDNDQINX $9 / 13 / 93 \quad 13: 40: 52$ MELCOR HP

Figure 3.19. 'Total Core Masses in MELC(O) Surry Midloop Calculations with Air Ingression 


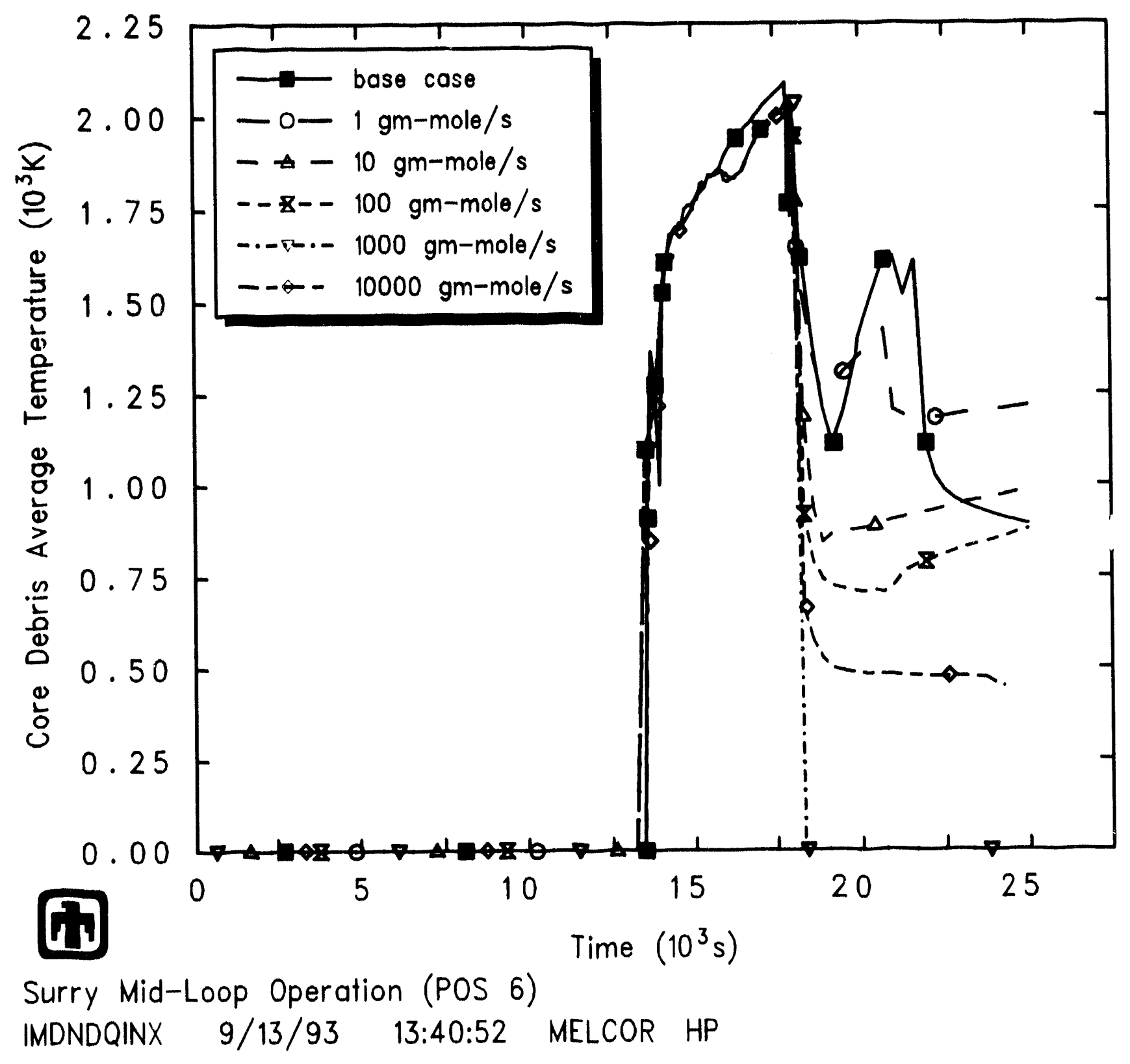

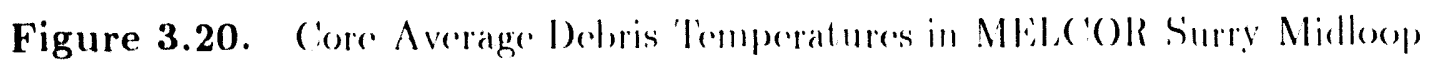
('alculations with $\mathrm{Air}$ Ingression 


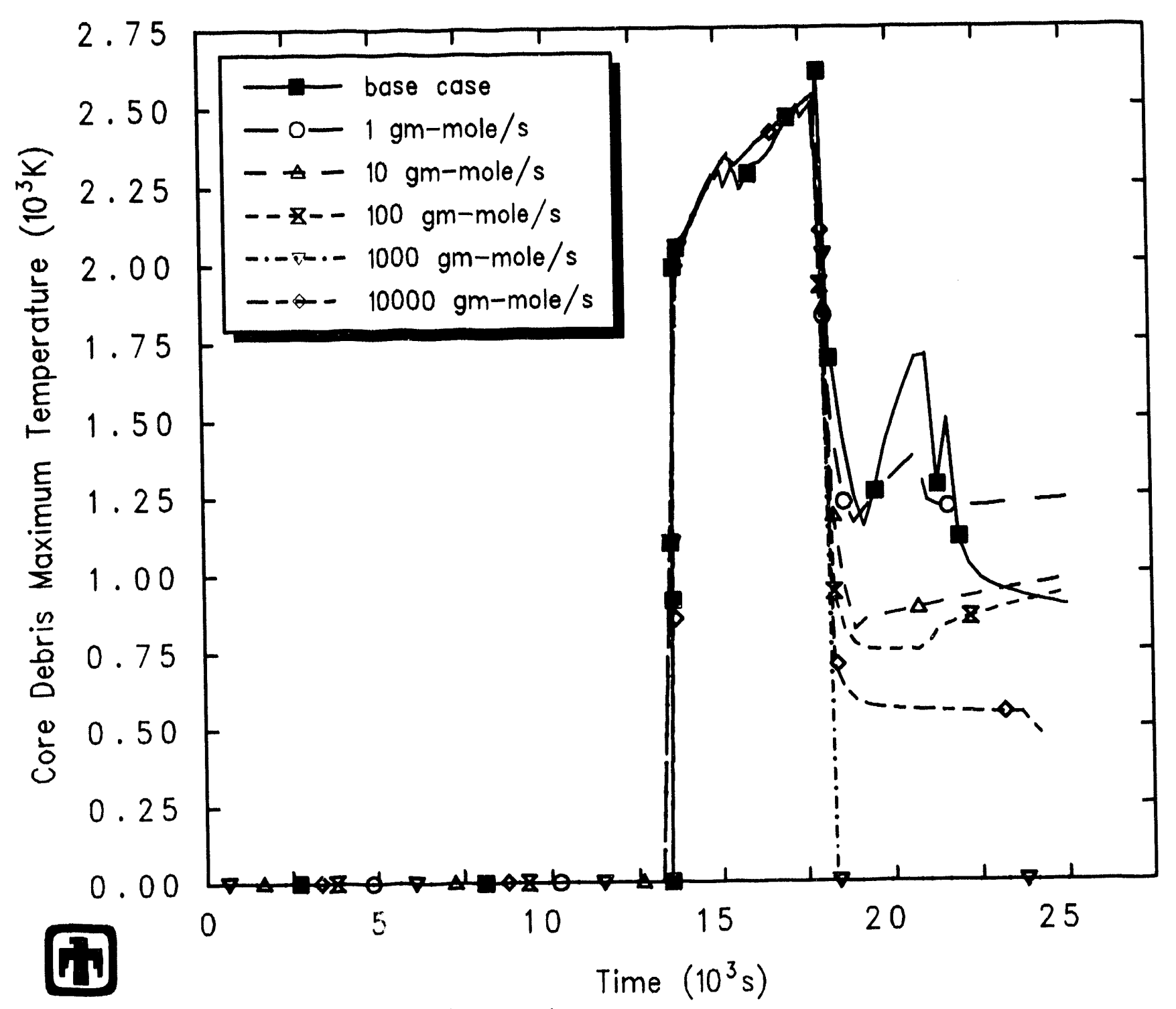

Surry Mid-Loop Operation (POS 6) IMDNDQINX 9/13/93 13:40:52 MELCOR HP

Figure 3.21. ('ore Maximum Debris Temperatures in Mlide(OR Surry Midloop ('alculations with Air lngression 


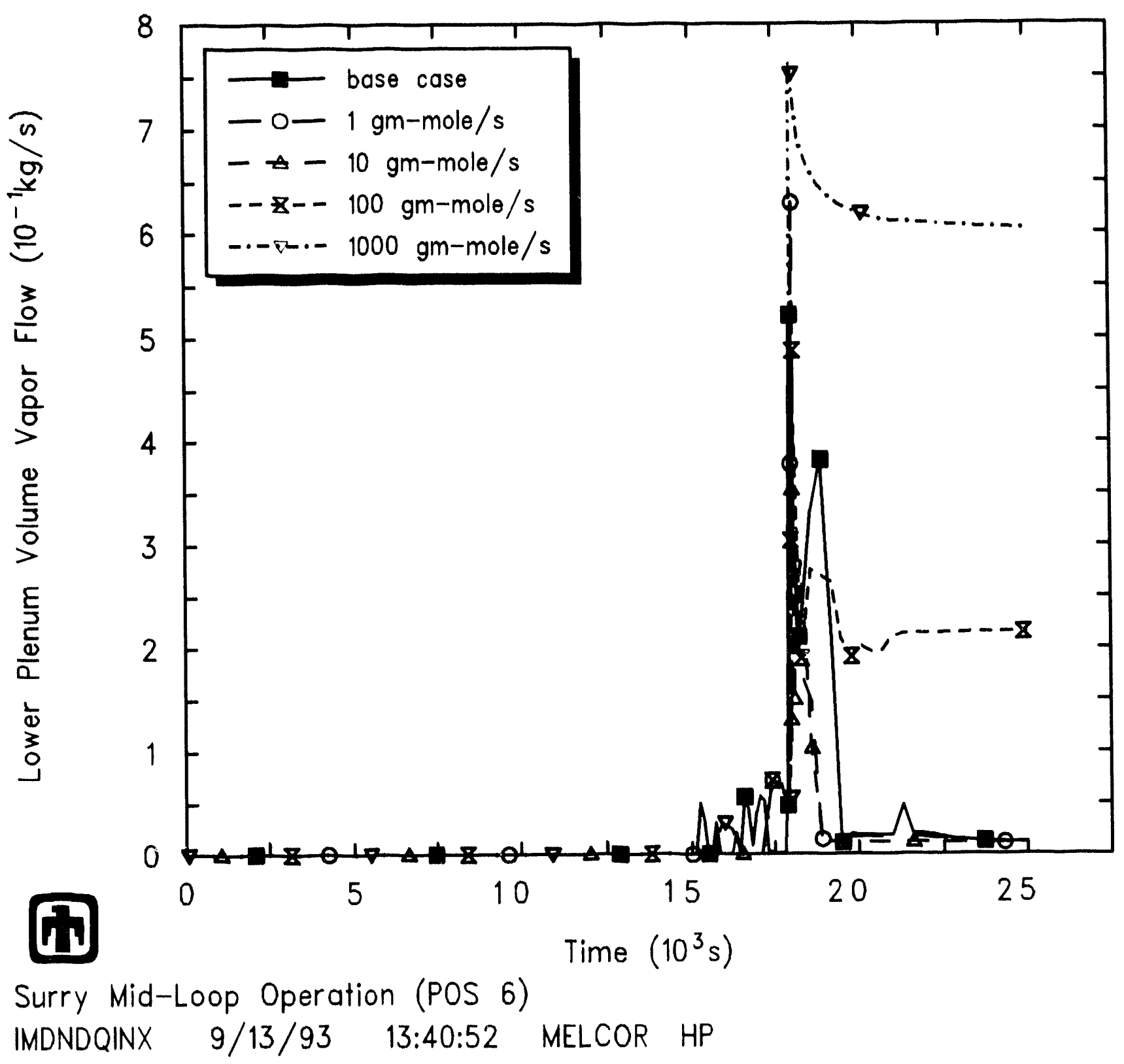

Figure 3.22. Lower Plenum Volume Vapor lilows in Mlid, (OR Surry Midloop) (Galculations with Air Ingression 
Table 3.2. In-Vessel Ruthenium Release in MELCOR Surry Midloop Calculations with Air Ingression

\begin{tabular}{cc|ccc}
\multicolumn{2}{c}{$\begin{array}{c}\text { Air Ingression } \\
\text { Rate }\end{array}$} & \multicolumn{3}{c}{$\begin{array}{c}\text { In-Vessel Release } \\
\text { (\% Initial Inventory) }\end{array}$} \\
$(\mathrm{kg} / \mathrm{s})$ & $($ mole/s) & Core & Lower Plenum & Total \\
\hline 0 & 0 & $1.3 \times 10^{-6}$ & $1.92 \times 10^{-5}$ & $2 \times 10^{-5}$ \\
0.032 & $\simeq 1$ & 0.07 & 3.67 & 3.74 \\
0.32 & $\simeq 10$ & 9.24 & 1.44 & 10.68 \\
3.2 & $\simeq 100$ & 71.64 & .003 & 78.64 \\
32 & $\simeq 1,000$ & 78.64 & 15.31 & 93.95 \\
320 & $\simeq 10,000$ & 79.17 & 19.57 & 98.74 \\
3200 & $\simeq 100,000$ & 79.23 & 20.54 & 99.77
\end{tabular}

Very little of the oxygen sourced into the core as part of the air ingression is cons'umed in Zircaloy oxidation. Table 3.3 presents the total amount of oxygen in the air ingression, the anounts of oxygen and steam consumed in-core by oxidation reactions, the amount of hydrogen produced in-vessel (through metal reaction with steam), and the total oxidation energy. The stcam consumption and hydrogen production drop only slightly $(\leq 5 \%)$ over a wide range of air ingression rates. As would be expected, the oxidation energy rises as more oxygen is consumed, because of the enhanced heat generation from the $\mathrm{Zr}+\mathrm{O}_{2}$ reaction vs reaction with steam, but the increase is not very great because so little of the injected oxygen is consumed. Note that the amount of steam consumed in oxidation. the amount of hydrogen produced and the total oxidation energy include Zire aloy oxidation with steam prior to the specified air ingression (in addition to Zircaloy reaction with oxygen during air ingression), as well as oxidation of core and lower plenum structural steel with steam throughout the transient period calculated; there is currently no provision in MELCOR to edit the Zircaloy and steel oxidation reactions separately.

The assumed air ingression has the greatest effect on the ruthenium release, but also a small effect on the release for other radionuclides. Table 3.4 gives the in-vessel releases as a percentage of initial inventory present, calculated for other radionuclide classes. Note that, with the (ORSOR-M option used, there is no in-vessel release of Class 7 (the early transition elements, represented by Mo). (Jass 9 (the trivalents, represented by La) or ('lass 11 (the more volatile main group eloments, represented by (d). As the rate of air ing "ession assumed is increased, there is very little change in the release fractiuns of the volatiles (i.c., the noble gases. the alkali metals represented by ('s and the halogens represented by I). There is also very little change in the release fraction of the chalcogens. represented by 'Te, and apparenily very little holdup in unoxidized Zircaloy clad in any case. Small increases in release fraction are seen for the alkaline eartlis. represented by 3 a, and the less volatile main group elements, represented by Sn; 
these two classes are intermediate in release $(\sim 1 \%)$ betwen the volatiles $(\leq 100 \%$ relcase) and the refractories ( $\ll 1 \%$ release), and the small increases in release probably reflect the enhanced clad/fuel heatup from the $\mathrm{Zr}+\mathrm{O}_{2}$ reaction. In contrast, there is a decrease in the trace amounts of refractories released, for both the tetravalents represented by (e and for uranium. in the calculations with air ingression assumed; this is probably due to the cooling effect of the air ingression on the core debris. There may be other changes in fission product release with air ingression, if other speries are also sensitive to the oxygen potential as is ruthenium; however. any such additional effects air could have on the release and transport characteristics of other radionuclides were not modelled for these initial calculations. (For instance, we expect the I releases predicted remain very small because the reaction $\mathrm{UO}_{2}+1 / 2 \mathrm{O}_{2} \rightarrow \mathrm{UO}_{3}(g)$ was not modelled; since this reaction generates a gaseous uranium oxide form. it wonld obviously greatly increase the release of 1 from the fuel.) 
Table 3.3. In-Vessel Oxidation in MEl(COR Surry Midloop Calculations with Air Ingression

\begin{tabular}{|c|c|c|c|c|c|}
\hline \multicolumn{2}{|c|}{ Air Ingression } & \multicolumn{2}{|c|}{ Consumed in Oxidation } & \multicolumn{2}{|c|}{ Produced in Oxidation } \\
\hline $\begin{array}{c}\text { Flow Rate } \\
\text { (mole/s) }\end{array}$ & $\begin{array}{c}\text { Total } \mathrm{O}_{2} \\
(\mathrm{~kg})\end{array}$ & $\begin{array}{c}\text { Oxygen } \\
(\mathrm{kg})\end{array}$ & $\begin{array}{l}\text { Steam } \\
(\mathrm{kg})\end{array}$ & $\begin{array}{c}\text { Hydrogen } \\
(\mathrm{kg})\end{array}$ & $\begin{array}{c}\text { Energy } \\
(\mathrm{MJ})\end{array}$ \\
\hline $0 \dagger$ & 0 & 0.2044 & 1864 & 208.6 & 29,936 \\
\hline$\simeq 1 \dagger$ & 42.66 & 3.404 & 1823 & 204.0 & 29,257 \\
\hline$\simeq 10 \dagger$ & 426.1 & 9.938 & 1812 & 202.8 & 29,374 \\
\hline$\simeq 100 \dagger$ & 4,307 & 46.02 & 1804 & 201.8 & 30,519 \\
\hline$\simeq 1,000 \dagger$ & 42,380 & 111.8 & 1791 & 200.4 & 32,428 \\
\hline$\simeq 10,000 \ddagger$ & 355,500 & 81.73 & 1791 & 200.4 & 31,396 \\
\hline
\end{tabular}

frun to $24,222 \mathrm{~s}$, to code failure

Table 3.4. In-Vessel Rarlionuclide Release in MEL('OR Surry Midloop ('alculations with Air Ingression

\begin{tabular}{|c|c|c|c|c|}
\hline \multirow[t]{2}{*}{$\begin{array}{l}\text { Air Ingression } \\
\text { (mole/s) }\end{array}$} & \multicolumn{4}{|c|}{$\begin{array}{l}\text { In-Vessel Release } \\
\text { ( } \% \text { Intial Inventory) }\end{array}$} \\
\hline & ('Tass $1(\overline{X c})$ & (lass $2(0 \mathrm{~s})$ & (Iass 4 (I) & ('Tass 5 (Te) \\
\hline 0 & 80.95 & 80.98 & 80.94 & 79.05 \\
\hline$\simeq 1$ & 81.40 & 81.42 & 81.38 & 79.65 \\
\hline$\simeq 10$ & 81.24 & 81.27 & 81.25 & 79.47 \\
\hline$\simeq 100$ & 80.99 & 80.98 & 80.98 & 79.14 \\
\hline$\simeq 1,000$ & $80.8: 3$ & $80.8: 3$ & 80.81 & 78.95 \\
\hline$\simeq 10.000$ & 80.59 & $8(0.51$ & 80.57 & 78.67 \\
\hline & ('lass :3 (Ba) & ('lass 8 (c) & ('lass $10(1)$ & (lass $12(\mathrm{Sn})$ \\
\hline 0 & 0.217 & $8.241 \times 10^{-6}$ & $1.786 \times 10^{-3}$ & 2.646 \\
\hline$\simeq 1$ & 0.2669 & $1.8 .10 \times 10^{-6 i}$ & $1.3 .51 \times 10^{-3}$ & 3.218 \\
\hline$\simeq 10$ & 0.269 & $1.8366 \times 10^{-65}$ & $1.348 \times 10^{-3}$ & 3.213 \\
\hline$\simeq 100$ & $(0.26 .5)$ & $1.791 \times 10^{-6 j}$ & $1.319 \times 10^{-6}$ & 3.173 \\
\hline$\simeq 1,000$ & 0.26 .1 & $1.787 \times 10^{-6 i}$ & $1.316 \times 10^{-6 i}$ & 3.164 \\
\hline$\simeq 10,000$ & 0.262 & $1.784 \times 10^{-6 i}$ & $1.311 \times 10^{-3}$ & 3.144 \\
\hline
\end{tabular}




\section{MELCOR Surry TMLB' Calculations with Surge Line Break and Air Ingression}

A set of two MELc(O) calculations has been completed examining the impact from interaction of air with residual fuel following vessed rupture in the surry PWR for a station blackout scenario in which a surge line rupture has occured during the in-core damage phase of the accident. The surge line rupture is expected to create a "chimmeylike" flow of air into the core region following vessel breach [1]. While MELe (O) can calculate the inflow of gases from the eavity up though the core and out the surge line break in such a situation, it predicts little or no oxygen present in the cavity source region during this period as the original cavity atmosphere is all displaced by steam and noncondensables generated in cone-concrete interactions. Wither a sperilic code model for single-phase countercurrent flow or a noding with multiple subdivided flow pathe with different clevation differences, flow areas and loss coefficients would be needed to calculate hot carity gases flowing up into the dome (or out into the basement) simmlt aneonsly with colder containment atmosphere flowing down into the cavity. That noding modilication was not tried for the calculations in this study. Instead, air was somered inte the core region beginning immediately after vessel failure, at a rate dedemined from the sensitivity studies described in Section 3 lor mid-loop calculations with air ingression.

The deck used was our standard Sury lMLB' dock [18]. A high-pressure station blackout scenario was run with the most recent code version, and the vessed lower head calculated failure time determined to be $11,422 \mathrm{~s}$. A surge-line-break flow path was then added to the deck, and the valve controller specified to open the assumed surge-line break at $10,500 \mathrm{~s}$, the time selected as $\sim 15 \mathrm{~min}$ before vessel failure in the high-pressure secrlatio. At this time, the core is mostly mencovered and the core ontlet temperature and most of the clad temperatures are > $2273 k$. (This is smilar to the approach taken in previous MEI, COR analyses of a Surry station blackont with surge line failure, described in more (lotail in [22].)

A reference calculation was done with the surge line break and with no air ingression forced, and another calculation was done with $\simeq 100$ mole/s air ingression: both calcullations were run to 30,000 s. In the latter case, a flow path was defined going from the contaimment dome to the core, and a constant velocity flow was specified to stant immedi-

ately at vessel failure. The containment dome was used as the air sonter volume instead of the cavity because the cavity air was quickly displaced by steam and/or hydrogen, while the containment dome atmosphere remained mostly $\sim 80 \%-N_{2} / 20 \% / 1-O_{2}$ with less dilution by steam, hydrogen and of her noncondensables generated by core-concrete interaction. The velocity needed to obtain desired molar flows was estimated hased upon STP conditions, not adjusted for contaimment pressurization; the $220 \%$ increase between the actual flow obtained using a velocity estimated based on STP conditions and the desired air flow $(\simeq 100 \mathrm{~mole} / \mathrm{s})$ was considered negligible.

There was obviously no change in the transient secpuenee in these there calculations prior to the surge line failure. Initiating the surge line break interrupted the core heat-up 
and degradation process, with core level swell and enhanced steam cooling temporarily driving most of the core back to saturation temperatures. The heatup then resumed, and the vessel lower head failed at $14,555 \mathrm{~s}$, $\leq 1 \mathrm{~h}$ r later than in the high-pressure scenario. Figure 4.1 shows the swollen and collapsed liquid levels in the core for these three calculations, while Figure 4.2 shows the clad temperatures in a cell in the inner core ring, about $1.3 \mathrm{~m}$ above the core support plate and about $0.3 \mathrm{~m}$ below the core midplane, a typical response. (The location of that core cell can be found by referring to the MELCOR Surry core nodalization presented in Figure 3.1.)

Results for the two calculations with the surge line break, with and without users.pecified air ingression into the core, continued to remain identical until the air ingression specified began at the time of vessel failure. Table 4.1 summarizes the state of the various materials in the core active fuel region, core plate and lower plenum at the time a lower head penetration first fails (i.e., at vessel breach); this state is common to the surge line break calculations done with and withont air ingression, because the air ingression is specified to start at vessel breach. Masses of intact components and of debris components are given for each region, together with average temperatures for the debris in the lower plenum, and fractions of Tircaloy and sted oxidized by the time of vessel breach. The fraction of debris molten in each region is estimated from the average debris temperature, which in this case resulted in assuming that most of the Zircaloy, stecl, sted oxide and control rod poison in the debris are molten and that $\mathrm{UO}_{2}$ and $/ \mathrm{r} \mathrm{O}_{2}$ in the debris are solid (i.e., neglecting eutectics mixtures; this assumption is forced by the MELCOR ontput available to the analyst). Also given is the fraction of material relocated. This is generally larger than the fraction molten because material can melt and relocate, and then subsequently refreege or quench; also, MEL(OOR usually relocates $17 \mathrm{O}_{2}$ fuel as a solid, after clad collapse but before fuel melt.

(Note that the total material masses present in the core as shown in this table and in the various plots in this section differ from the corresponding results in for the midloop calculations with air ingression presented in Section 3, because in that input model the $\sim 30 \times 10^{3} \mathrm{~kg}$ of lower plemum structural stecl was modelled using heat structures, which cannot oxidize, melt or relocate, while in these TMIB' calculations with surge line rupture and air ingression that lower plenum structural sted was included in the core package modelling as material that conld oxidize, melt and relocate.)

The various materials in the MELCOR "fuel/elad" component just prior to vessel failure, both any intact materials remaining in their original position and candled, refrozen conglomerate debris materials, are shown in Figures 4.3 through 4.5 for the three radial rings in the MEL(COR Surry core model. Figures 4.6 through 4.8 show the materials calculated to be in the "particulate debris" component in the three core rings at the same time, while the various materials in the MELCOR "other-structure" component just prior to vessel failure, both intact materials and candled, refrozen conglomerate debris materials, are shown in Figures 4.9 through 4.11 for the three core rings in the MELCOR Surry core model. (Refer to [8] for an explanation of these MELC(OR components, if necessary.) The "elevation" used as the ordinate in Figures 4.3 through 4.11 is the same as the core level clevations shown in Figure 3.1, with the core support plate 


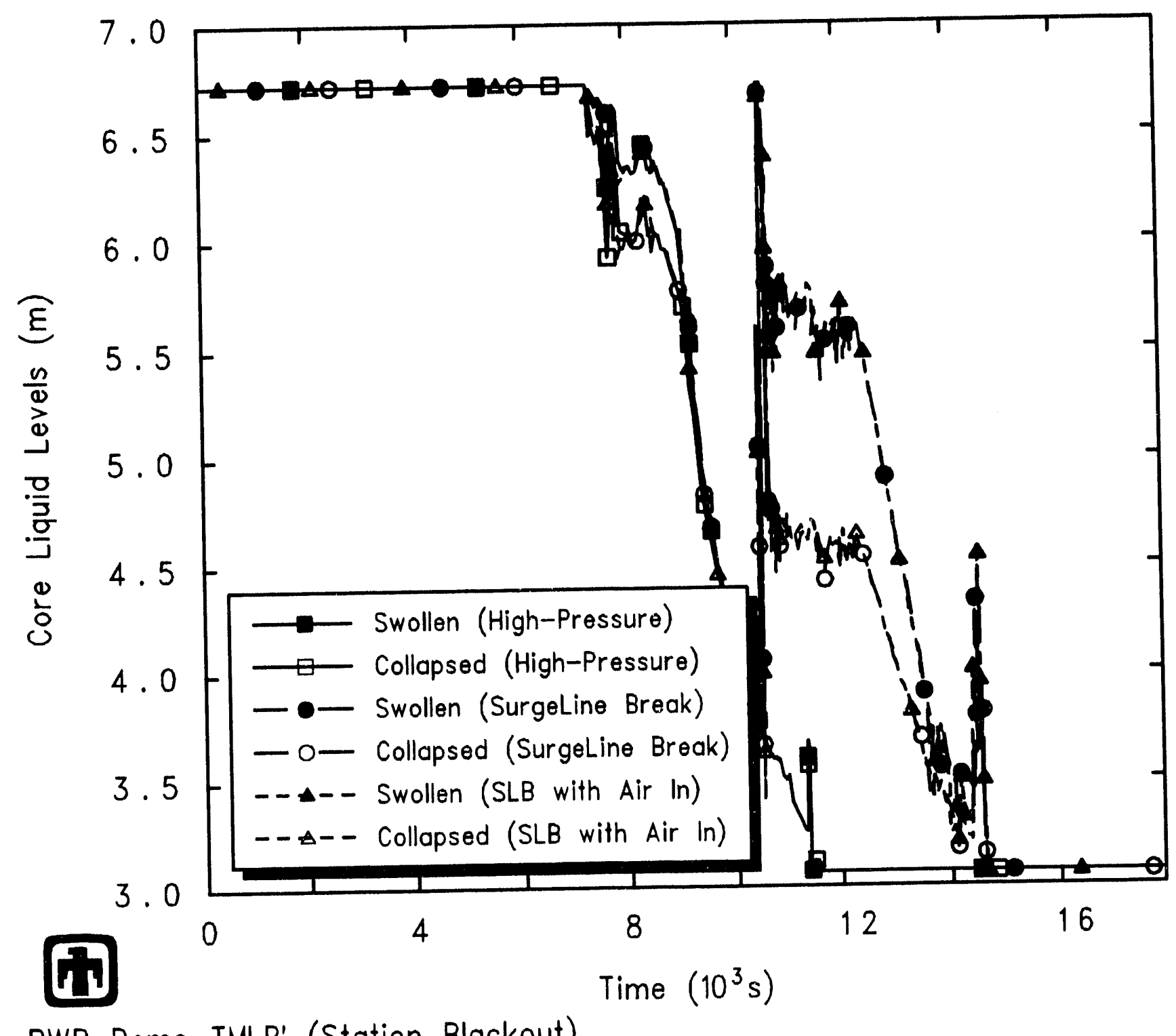

PWR Demo TMLB' (Station Blackout)

HODIALKNW 8/27/93 08:04:56 MELCOR HP

Figure 4.1. Core Liquid Levels in MELCOR Surry 'TMLB' Calculations with Surge line Break and $\mathrm{Air}$ Ingression 


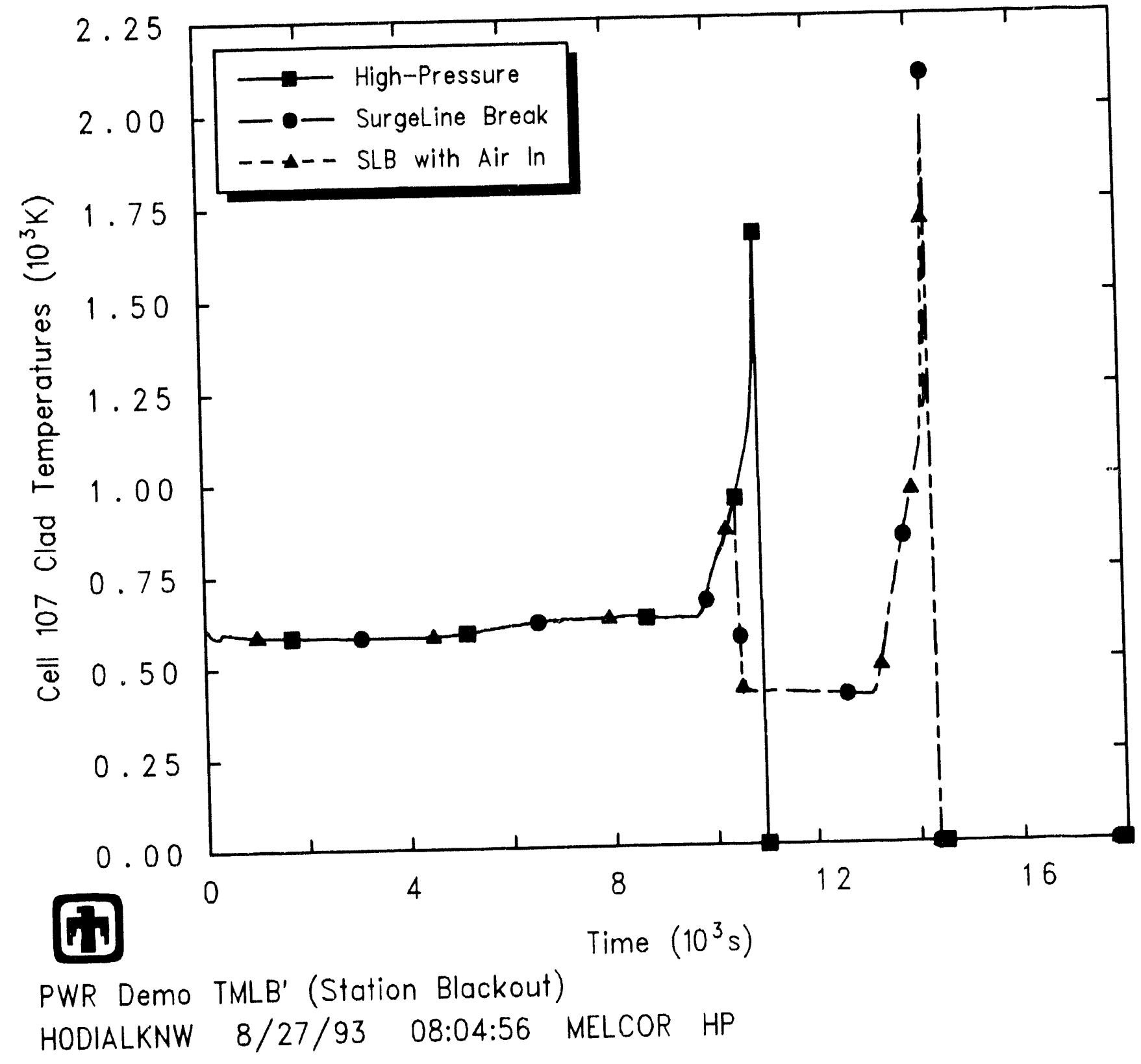

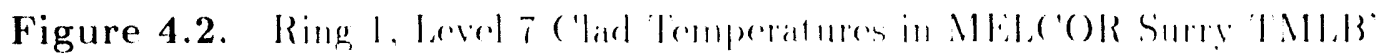
(alculations with Surge line Break and Air logeression 


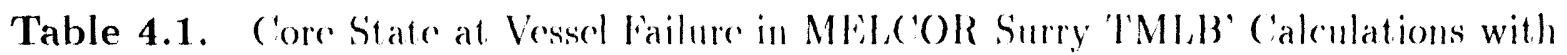
Surge Line Failure and Air Ingression

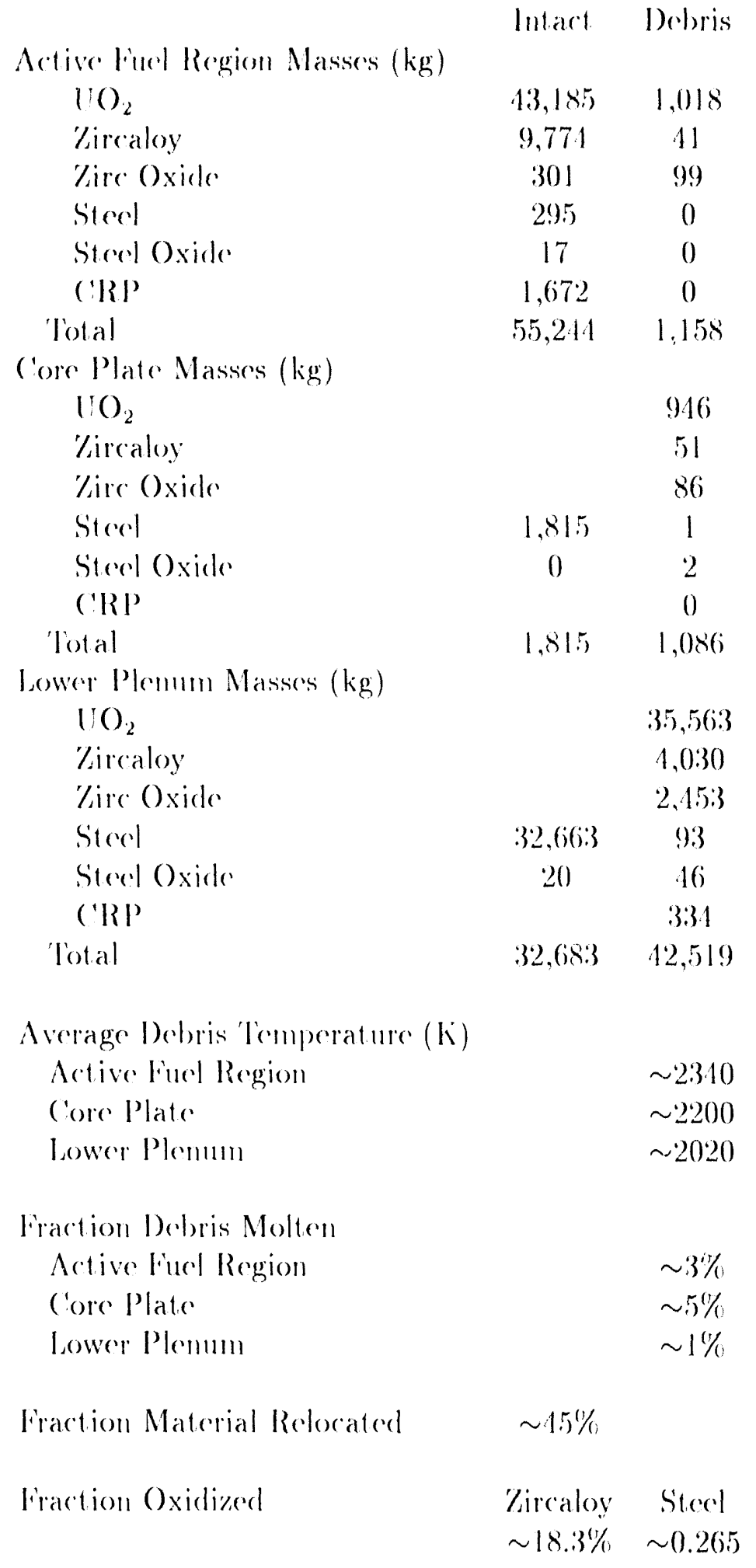


at $\geq 3 m$, the lower plemmon between 0 and $23 m$, and the active fued region from $\geq 3 m$ to $\sim 6.722 m$. The fraction of anch core cell occupied by any given material is shown. However, recall that the core colls are not enual in the three rings: the inmermest, highpowered ring includes $\sim 15 \%$ of the core, the middle ring contains $\sim 60 \%$ of the core, and the ontermost, low-power ring includes the remaining $\sim 25 \%$ of the core.

As in the core state at vessel failure for the midloop operation analyses, the immermost ring has no intact structure in the active fued region at all at the time of vessed failure for these surge-line break calculations (Figure 1.3). However, in this case there is a smaller but still substantial debris bed only in the lower plenum in that first ring (Figure 4.6), with a very small amount of debris still hede above the failing core plate. About half of the intact material remains in the active fued region in the second ring (Figure 4.1), with those intact materials together with the core plate supporting a small amount of particulate debris in the active fuel region (Figure 4.7 ); note that, mulike the results in the midloop operation core state predicted at vessel failure, a substantial debris bed is found in the lower plemm in the serend ring as woll as in the first ring in these full-power station blackout with surge line break calculations. Almost all of the intact material remains in place in the active fuel region in the third ring (ligure 4.5); there is little or no particulate debris retained in the active fuel region in the third ring (Figure 4.8), but again a substantial debris bed in the lower plemmon. 'The core plate it sell is clearly visible in Figures 4.9 through 4.11 as the very thin structure at $\geq 3$ m elevation; the substantial mass of lower plemum structural stecel modelled as a core component in these surge line break analyses is also clearly visible in Figures 4.9 throngh 1.11 . Some intact other structure and some candled, refrozen other structure, such as control rod poison and the control rod guide tube material, are visible in the midelle of the active fued region in Figures 4.10 and 4.11 . Note that only $\leq 20 \%$ of the Kircaloy (and < $1 \%$ of the stecl) has been oxidized up to this time, either in the intact chad or in the debris bed; most of the Zircaloy remains unoxidized in both the remaining intact elad and in the debris bed at the time of vessed failure and at the sperified stant of the assumed air ingression.

The air ingression begun at vessel breach does not produce any major changes in the subsequent aceident progression, but does affect the core atmosphere, the core materials and the fission product release, directly through air oxidation of the clad and contanced ruthenium release, and indirectly by slightly changing the later time core clad and debris temperatures. Figure 4.12 shows the chad temperatures in a coll in the outer core ring, about $2 m$ above the core support plate, with a slightly accelerated heatup of the clad just before melt and failure in the calculation with air ingression, due to the higher energy of reaction with air rather than with steam (a response typical of other core cells).

Figure 4.13 through 4.16 demonstrate the effect of the air ingression on the core mole fractions of steam and of nitrogen, oxygen and hydrogen, respectively. Withont any air ingression the core atmosphere consists mostly of steam prior to vessel failure and mostly hydrogen after vessel failure; with air ingression, the core atmosphere is $235 \%$ air and $\sim 60 \%$ stean after vessel failue, with very little ( $\leq 5 \%$ ) hydrogen due to the preferential oxidation of Zircaloy clad by reaction with oxygen. 


\section{Elevation (m)}

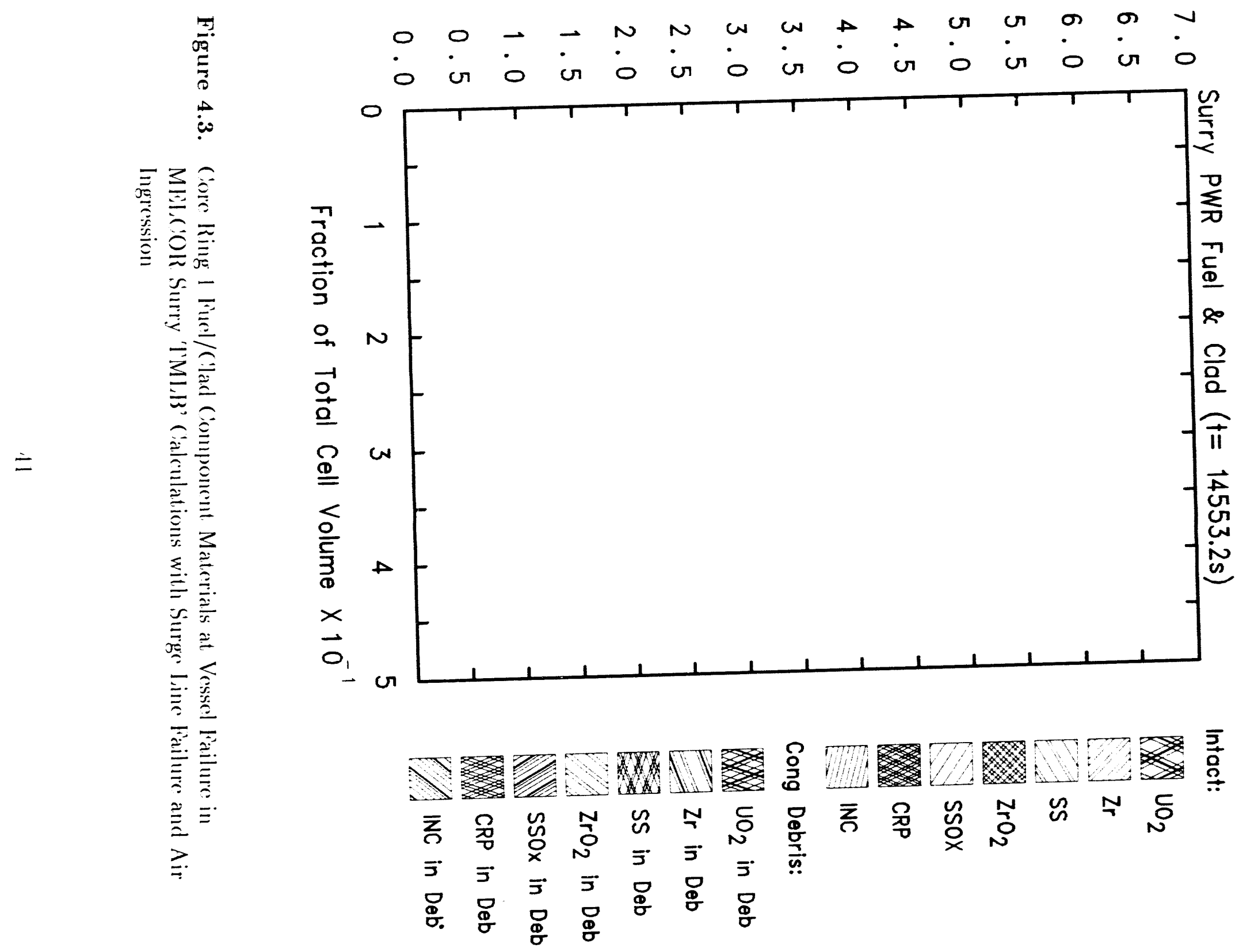




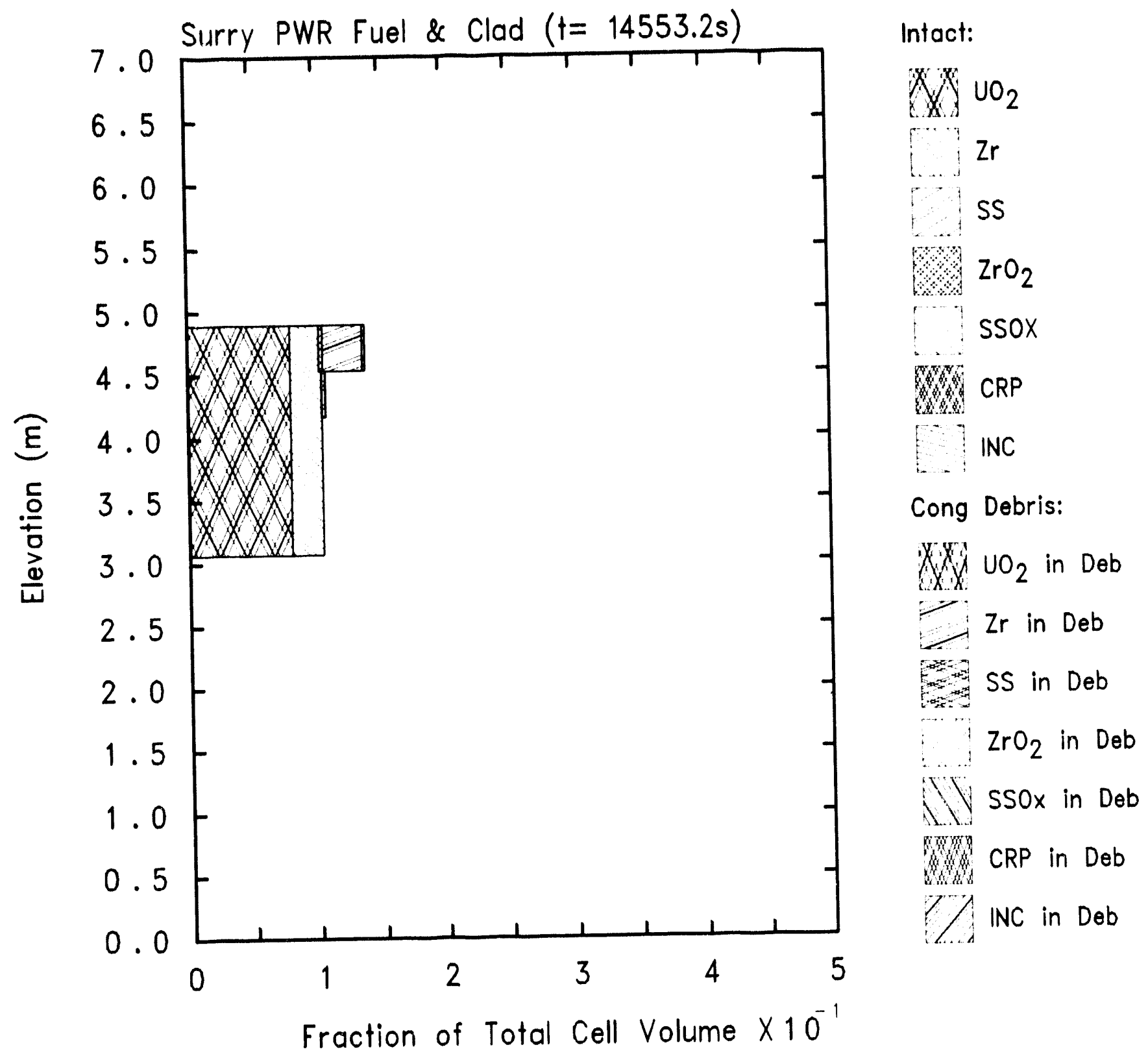

Figure 4.4. Core Ring 2 Fuel/Clad Component Materials at Vessel Failure in MELCOR Surry TMI, G' (alculations with Surge Line Failure and $\mathrm{Air}$ Ingression 


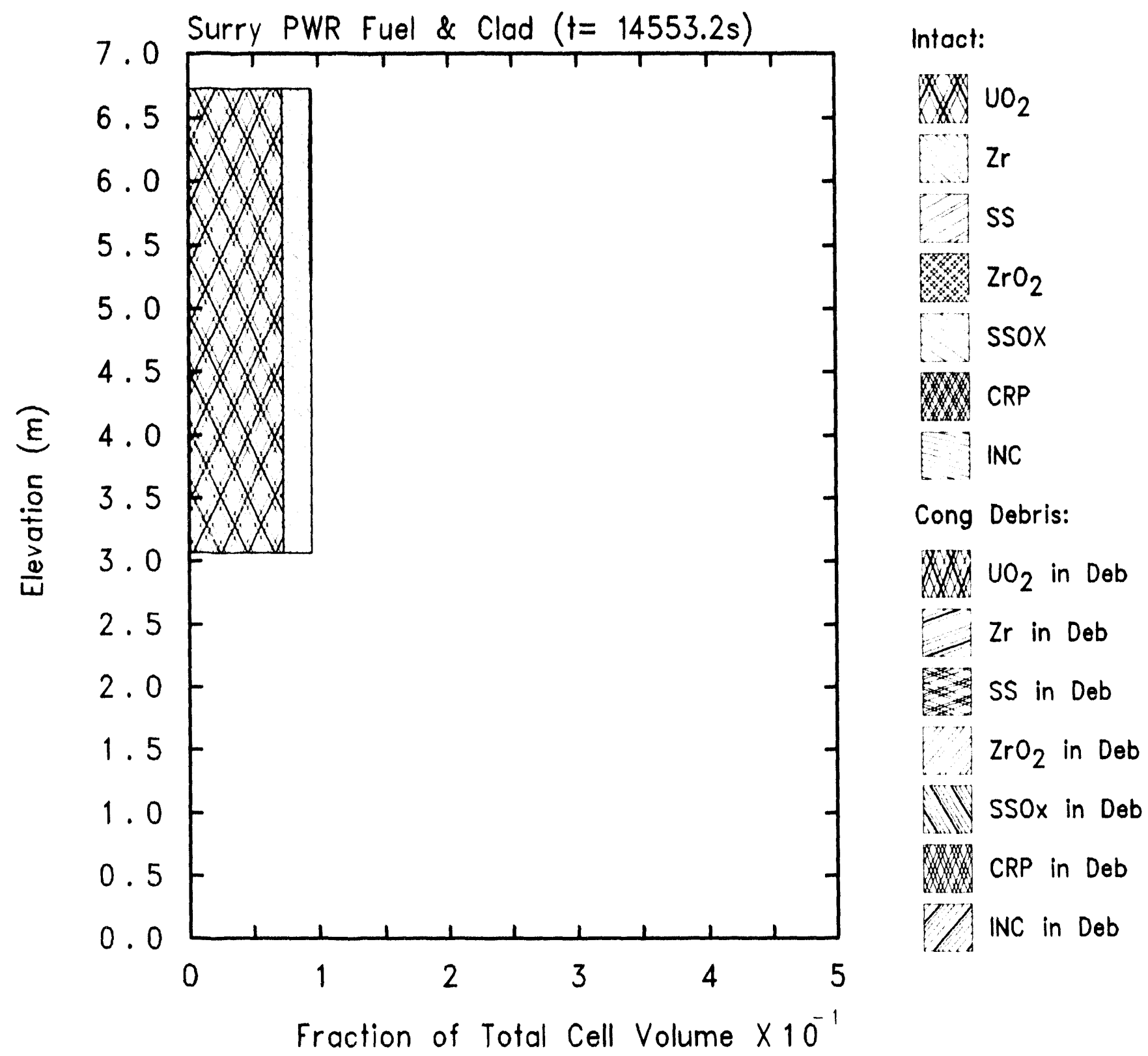

Figure 4.5. Core Ring 3 liuel/('lad ('omponent Materials at Vessel Failure in MLLCOR Surry 'TMLB' ('alculations with Surge Line l'ailure and Air Ingression 


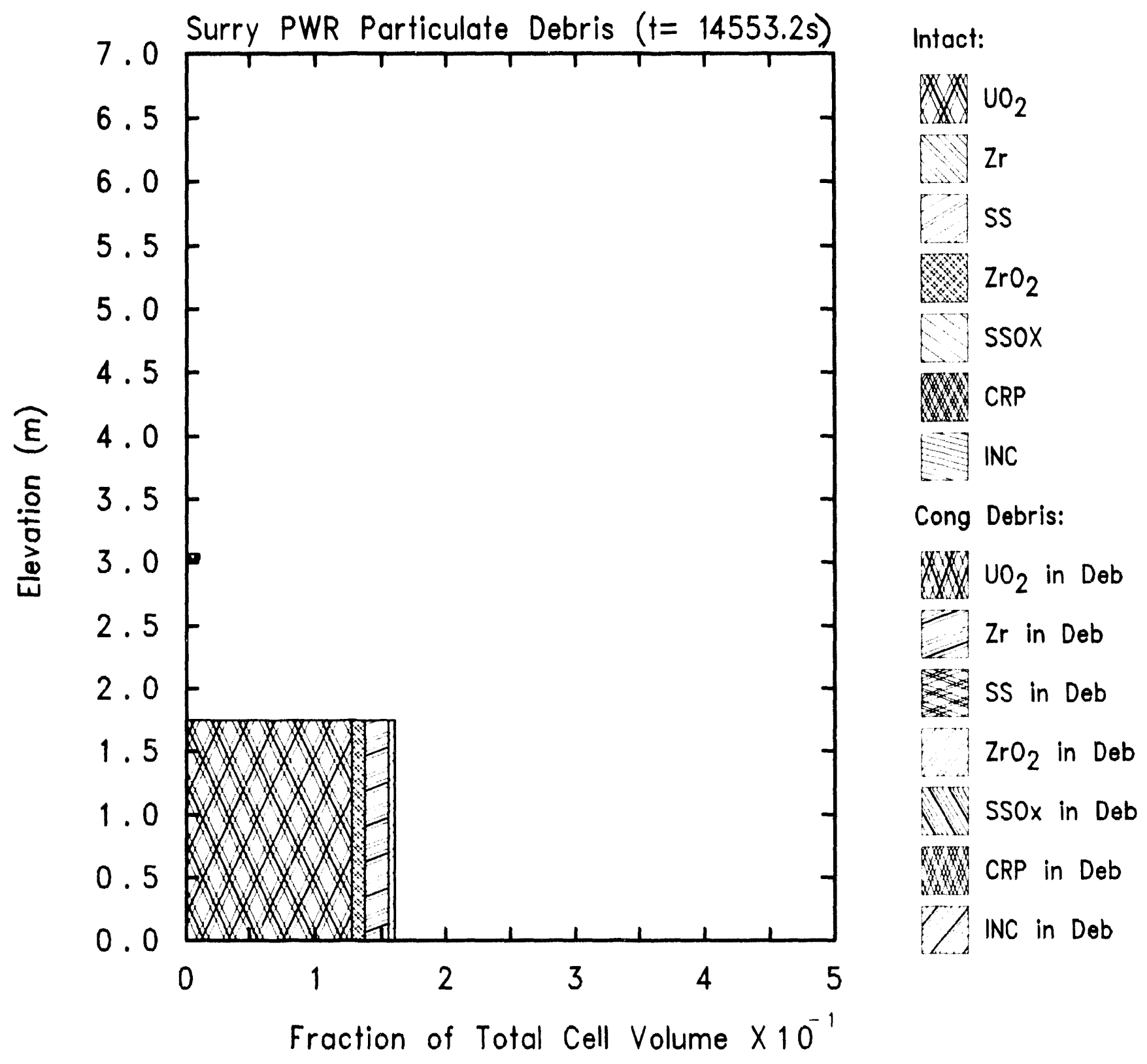

Figure 4.6. Core Ring 1 Particulate Debris (omponent Materials at Vessel Failure in MELCOR Surry TMLI3' Calculations with Surge Line Failure and Air Ingression 


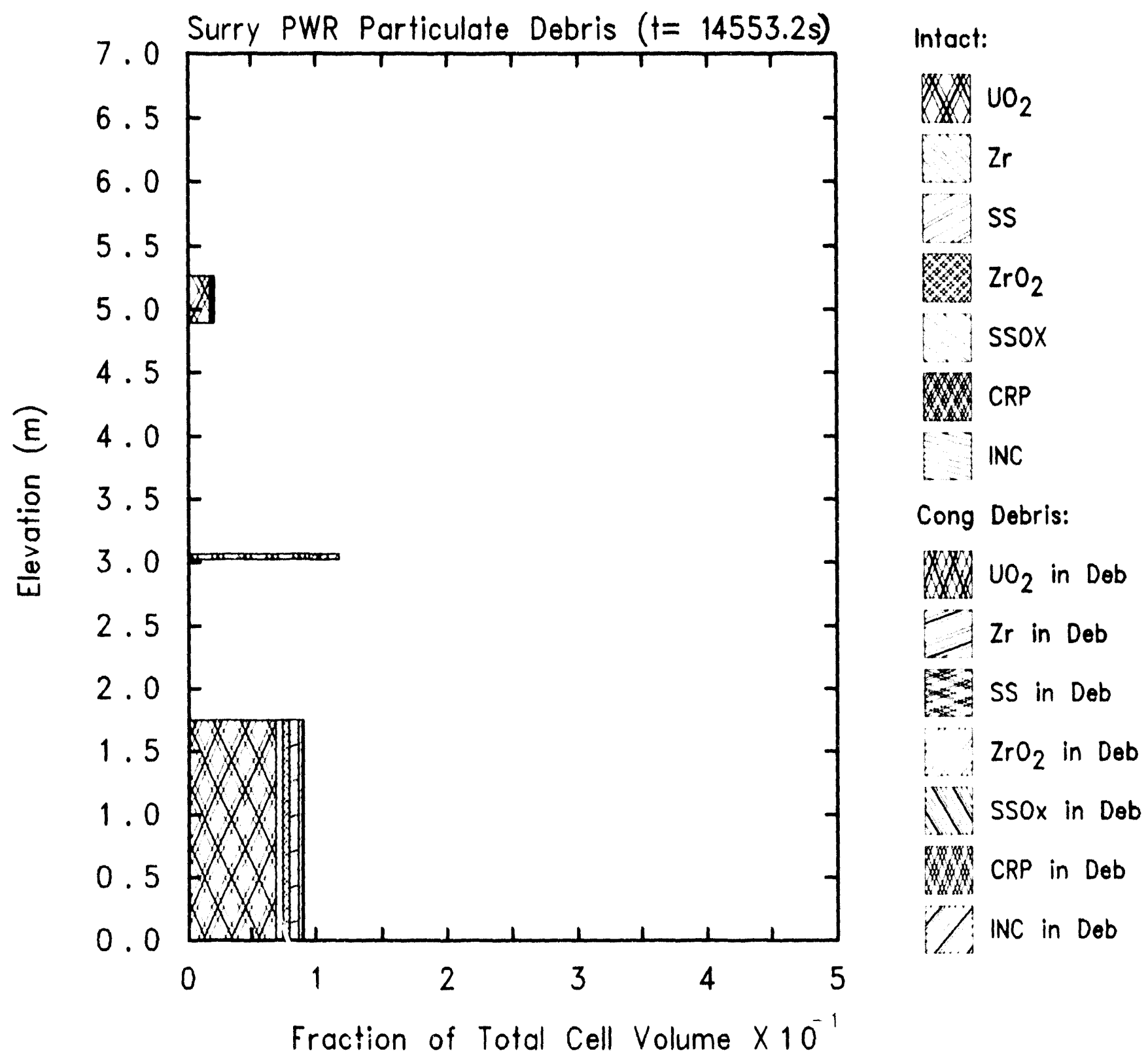

Figure 4.7. ('ore Ring 2 Particulate Dobris (omponent Materials at Vessel failure in Mlide(')R Surry 'TMLB' (alculations with Surge line Failure and $\mathrm{Air}$ Ingression 


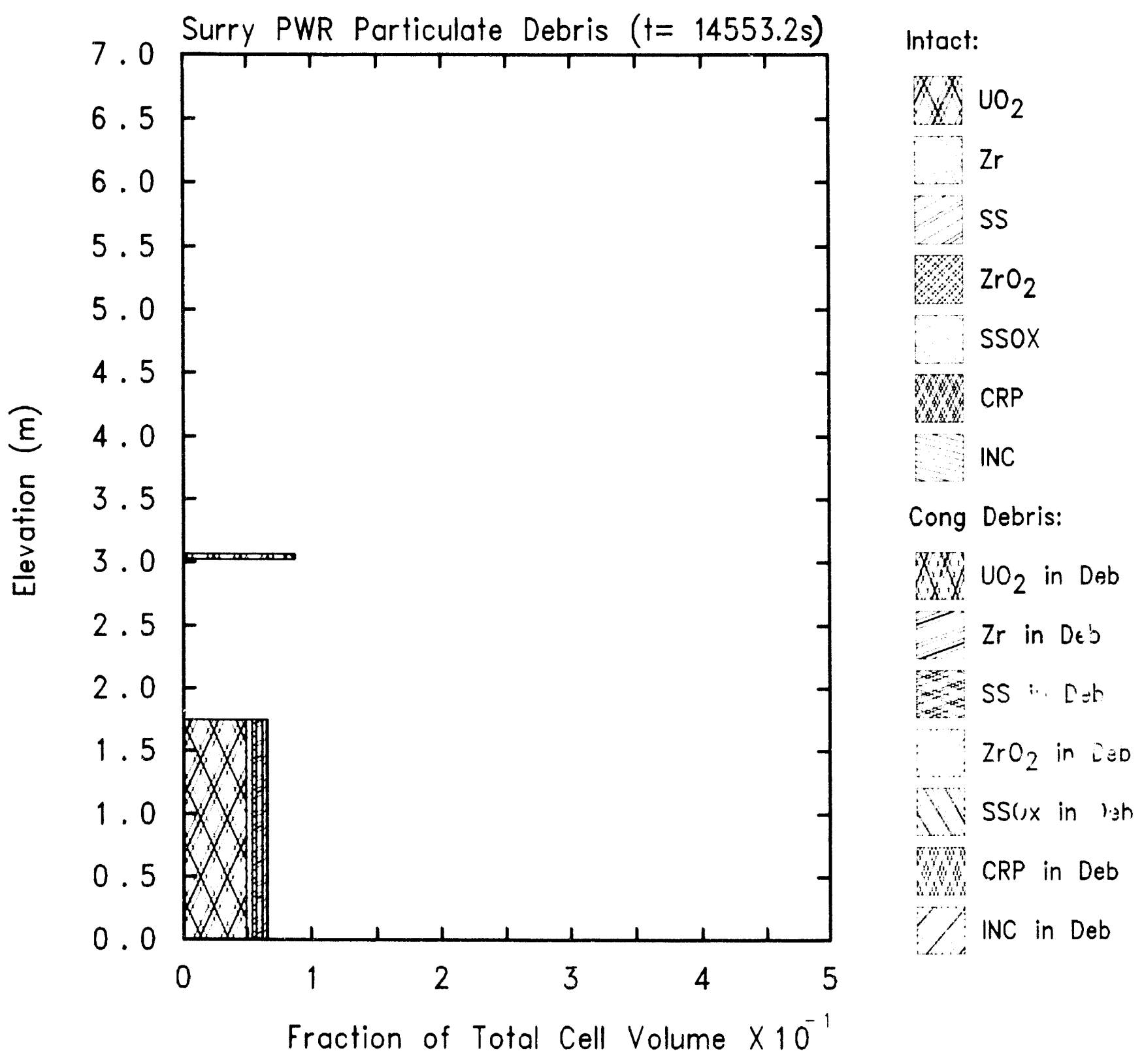

Figure 4.8. ('ore Ring 3 Particulate Debris ('omponent Materials at Vessel Failure in MELCOR Surry TMLB' ('alculations with Surge Line Failure and Air Ingression 


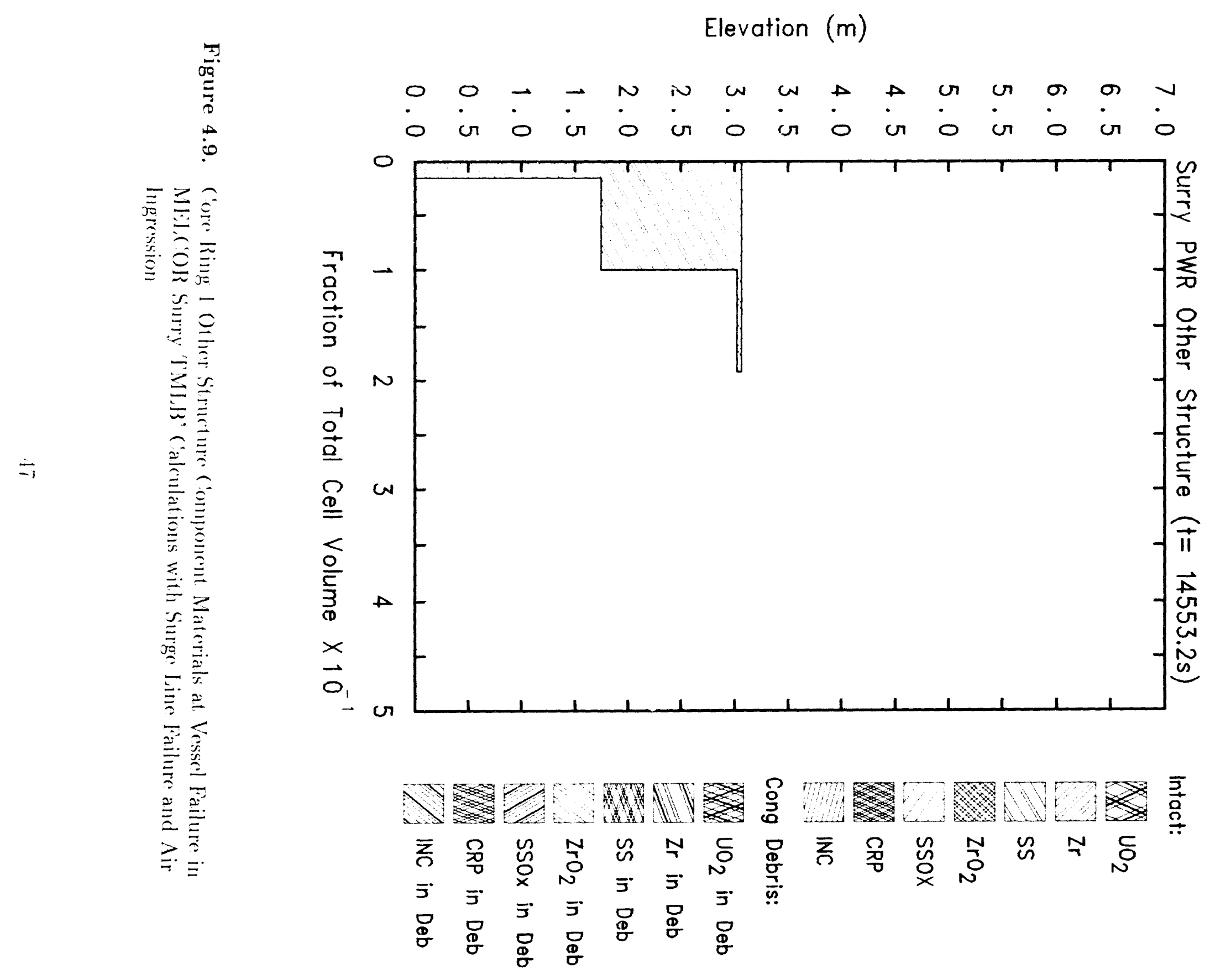




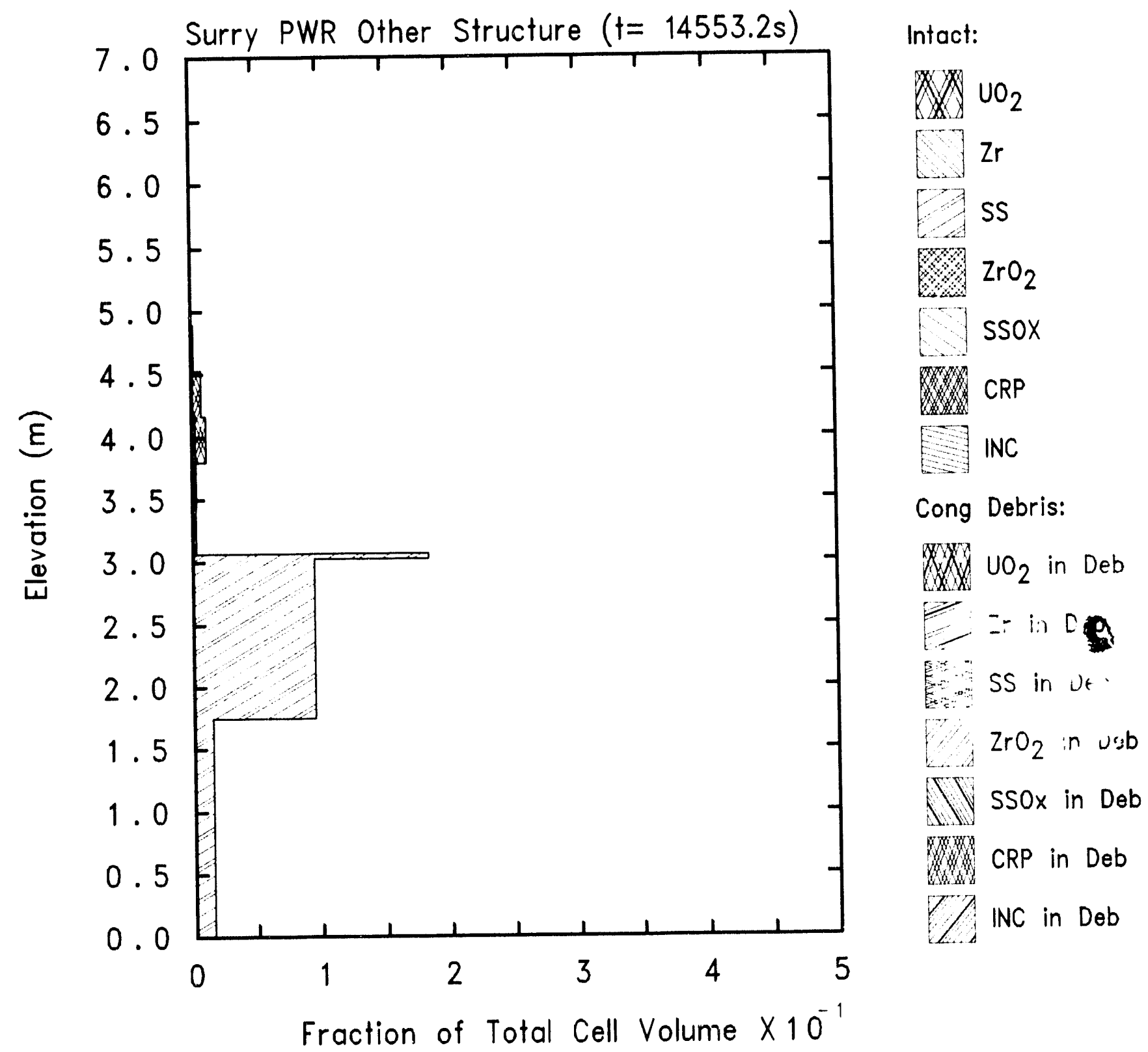

Figure 4.10. Core Ring 2 Other Structure Componeni Materials at Vessel Failure in MELCOR Surry 'TMLB' Calculations with Surge Line Failure and Air Ingression 


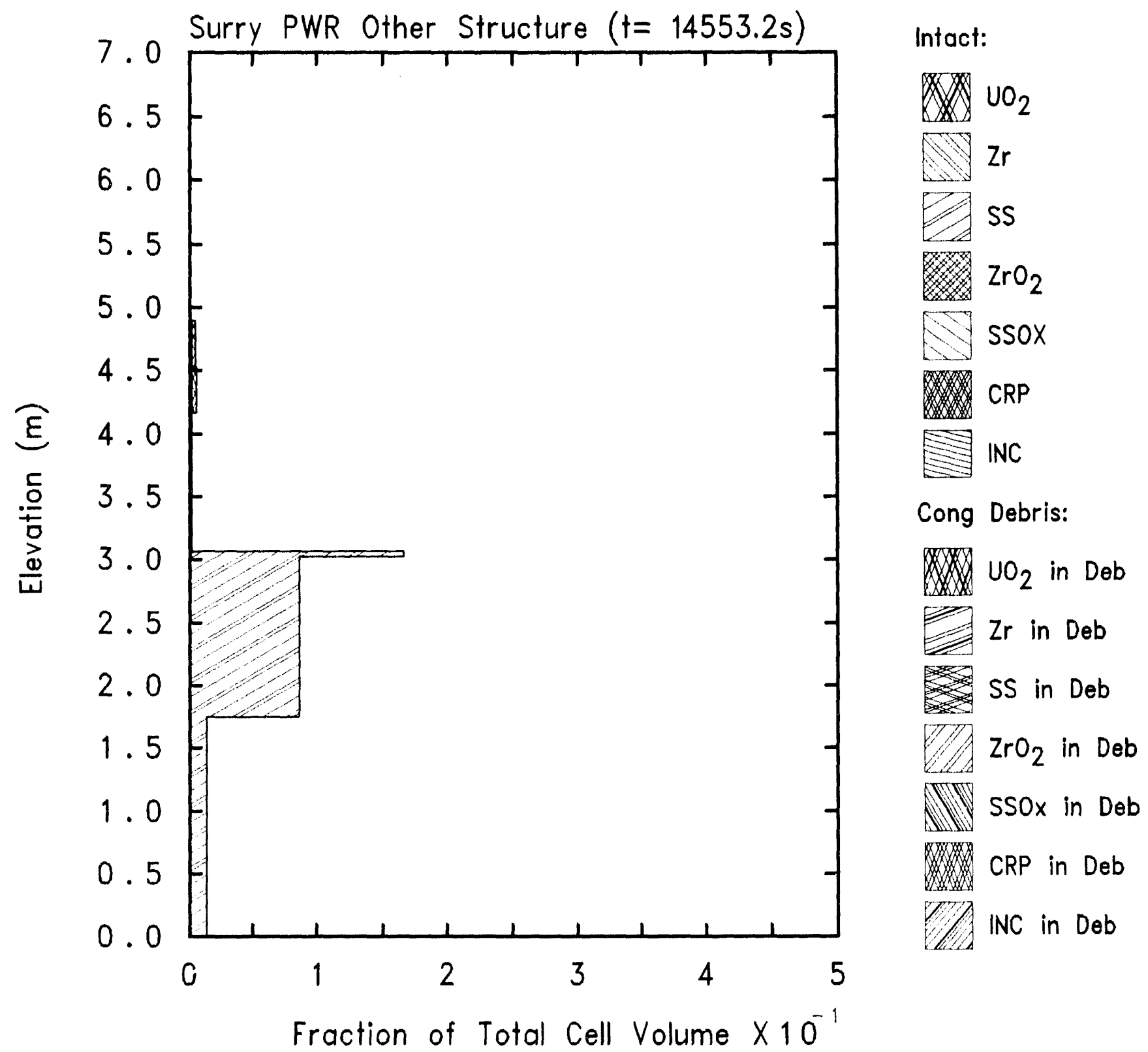

Figure 4.11. Core Ring 3 Other Structure Component Materials at, Vessel Failure in MELCOR Surry 'TMLB' Calculations with Surge Line Failure and Air Ingression 


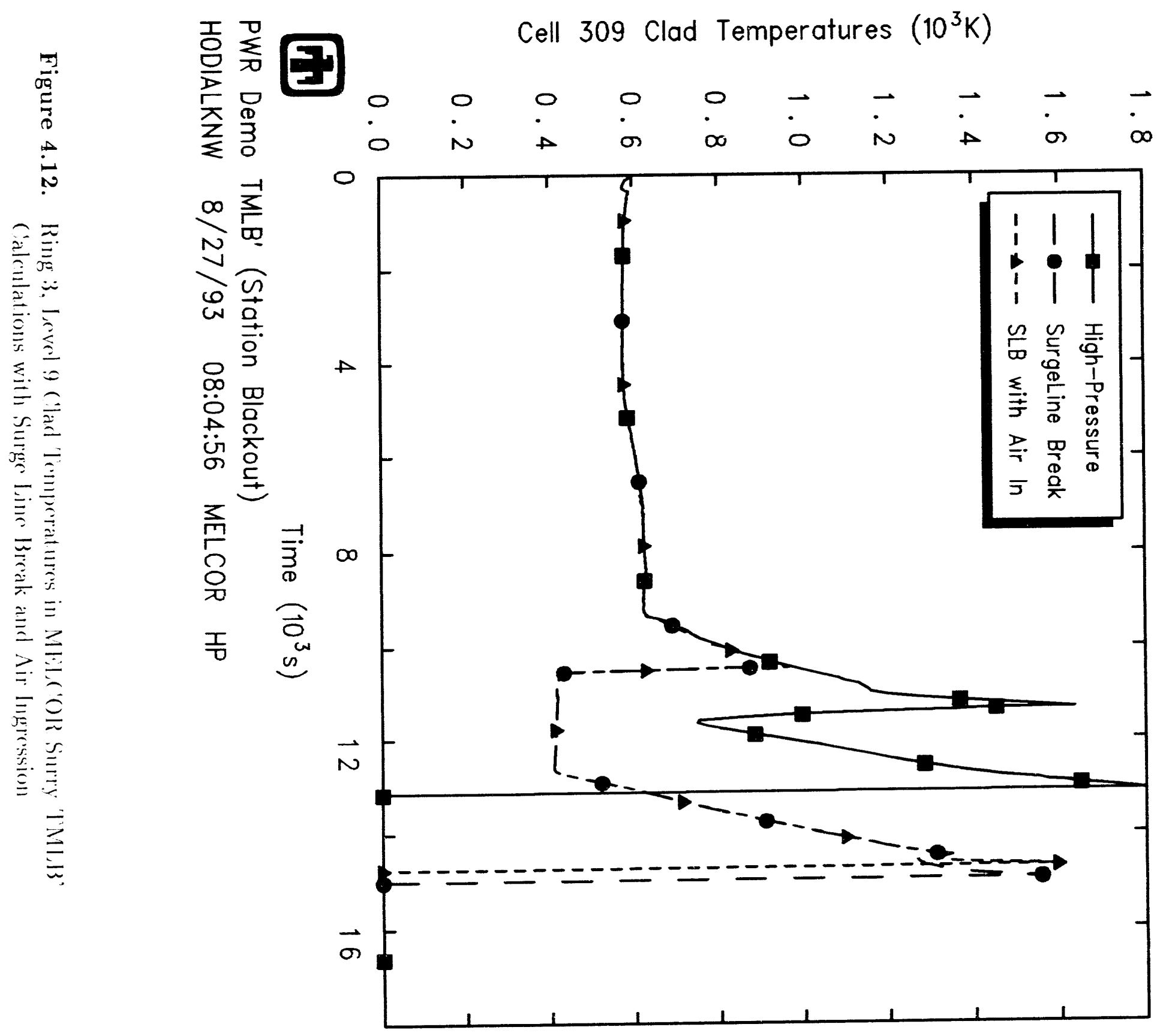




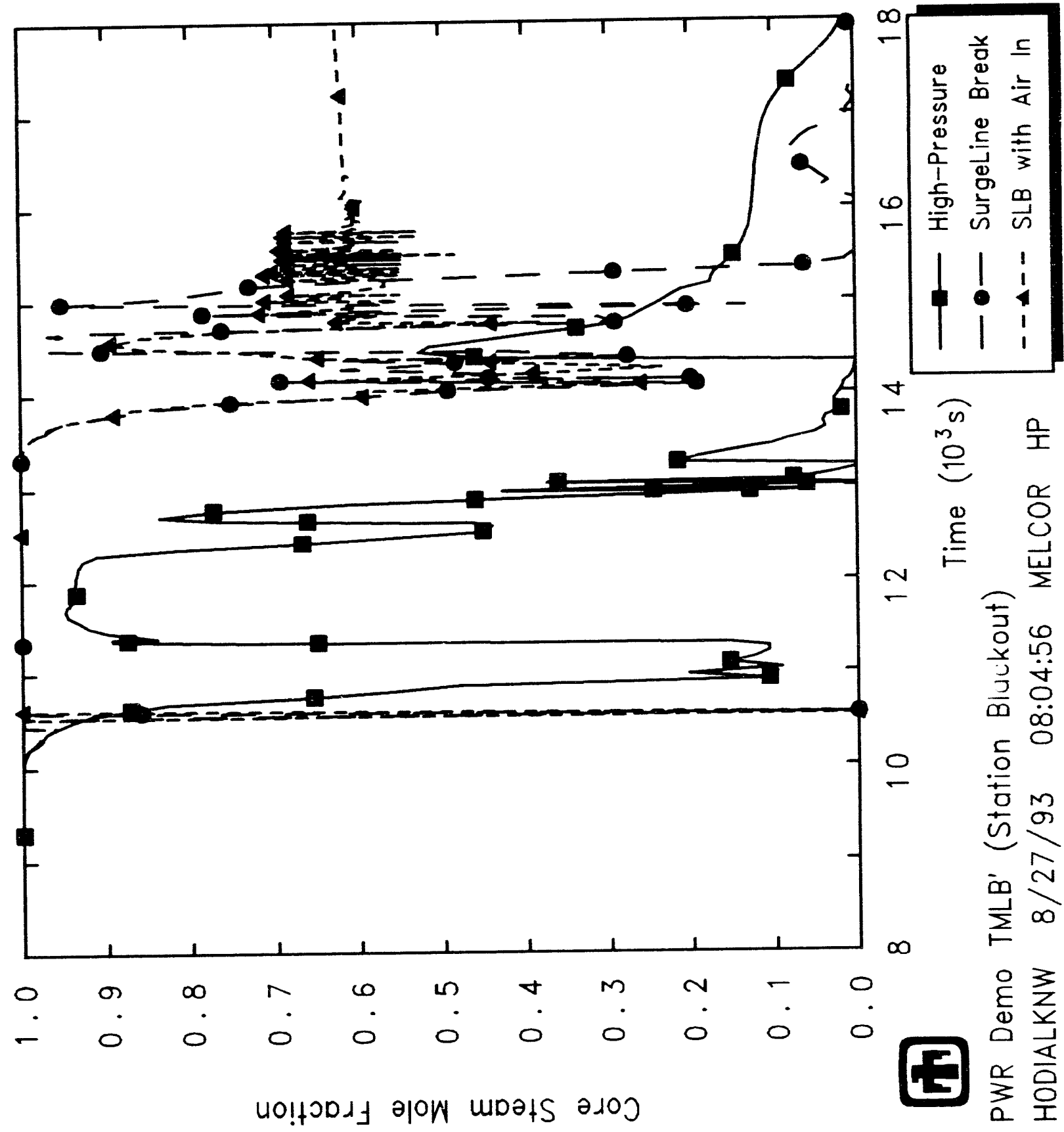




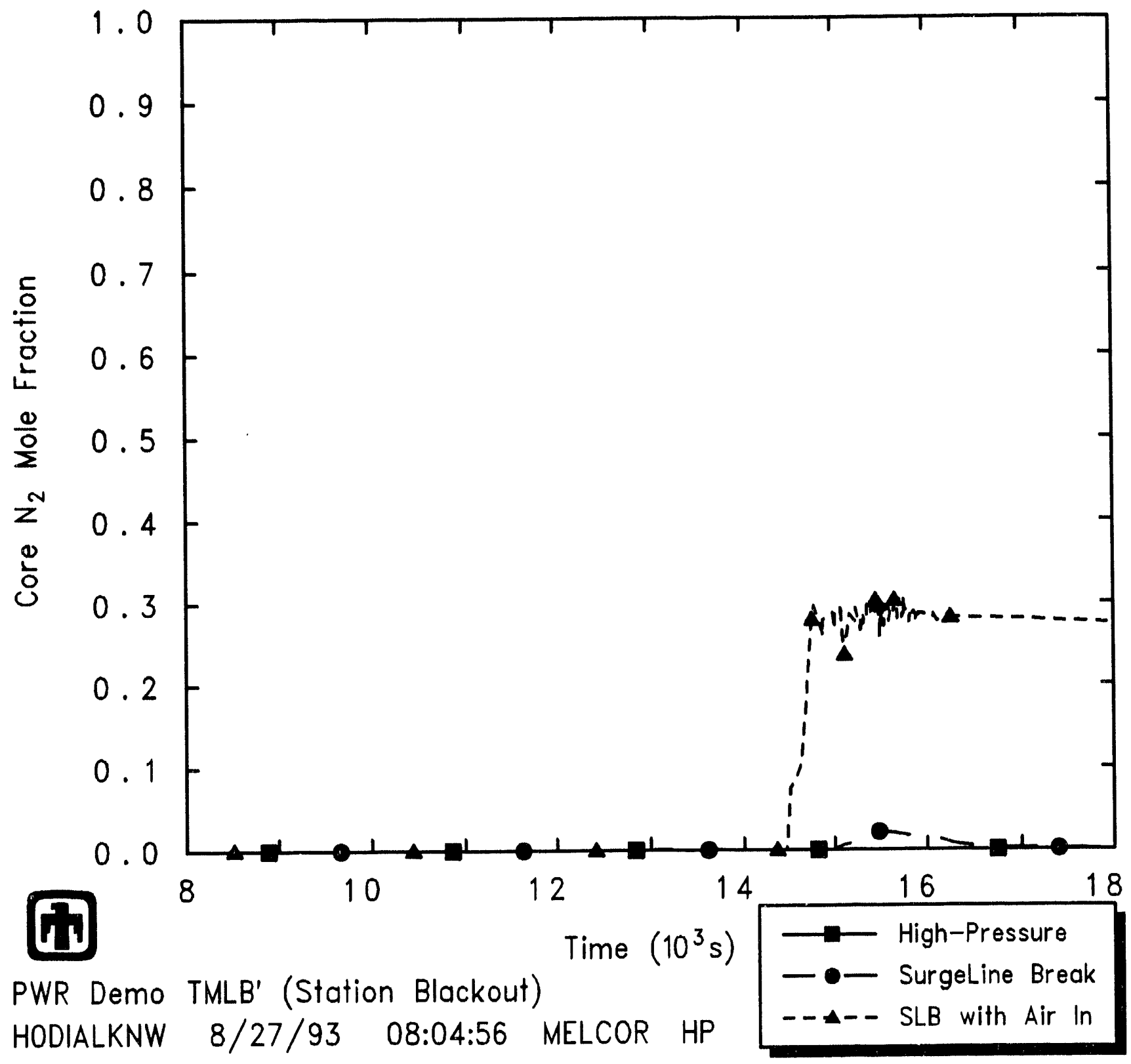

Figure 4.14. Core Active Fuel Region Nitrogen Mole Fractions in MELCOR Surry TMLB' ('alculations with Surge Line Break and Air Ingression 


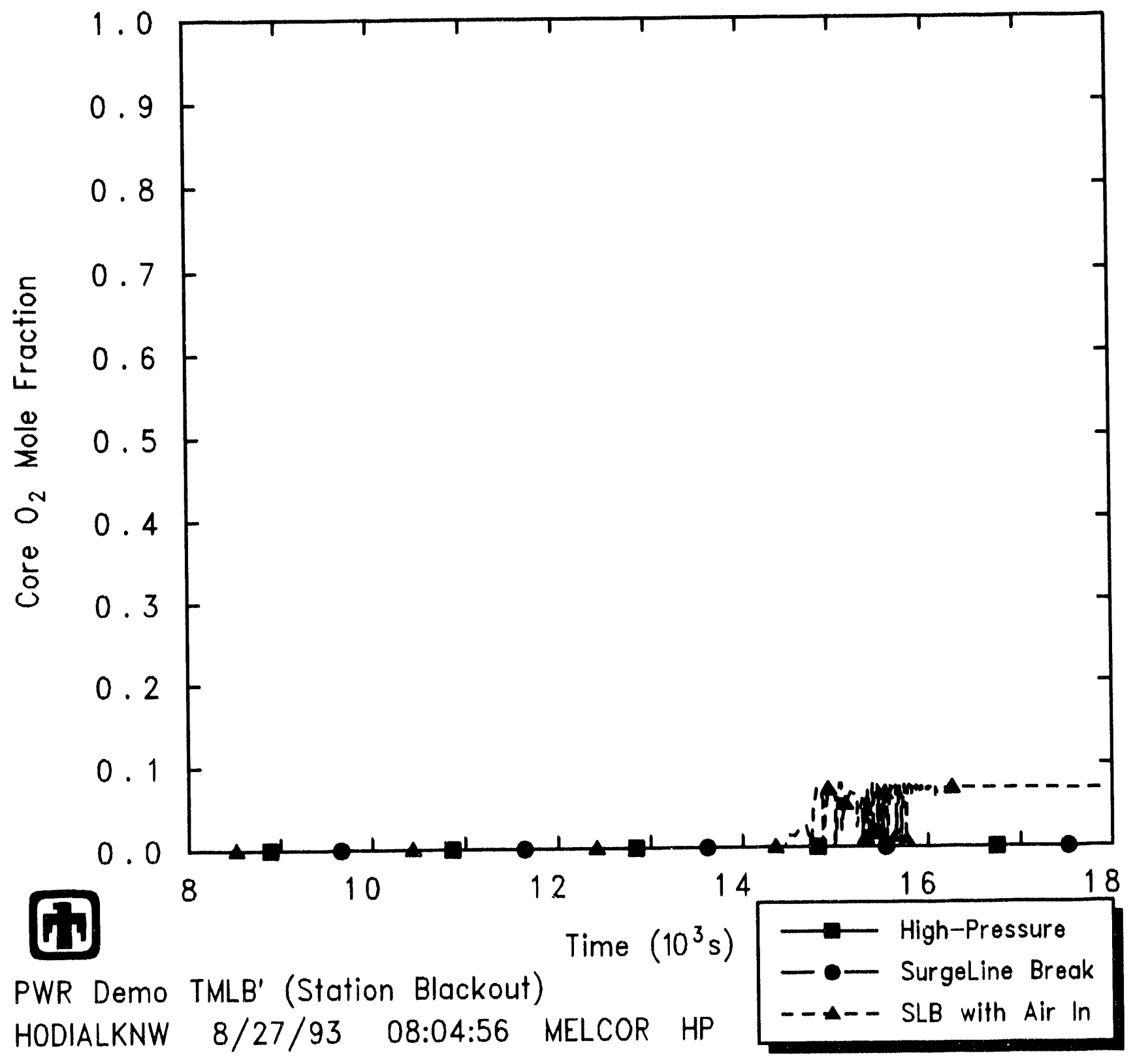

Figure 4.15. ('ore Active Fuel Region ()xygen Mole leations in MFLc OR Surry 'I'MI,B' (alculations with Surge line Break and Air Ingression 


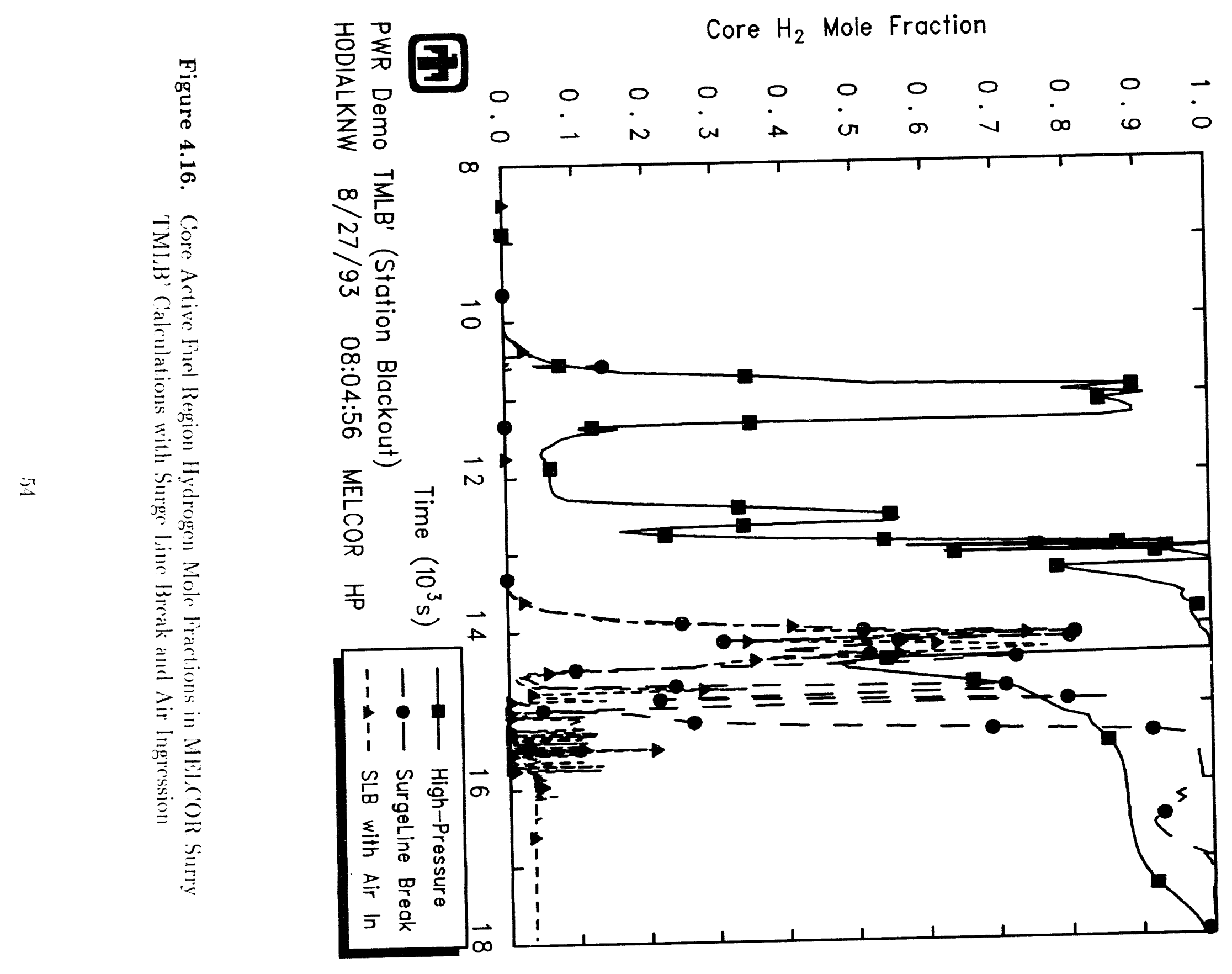


The biggest difference in results in the two calculations with the surge line break, with and without user spereflied air ingression into the core, is foumb in the ruthenimm fission

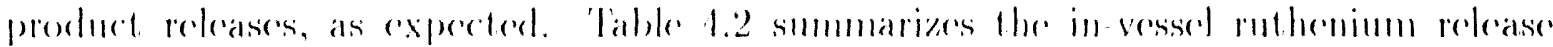

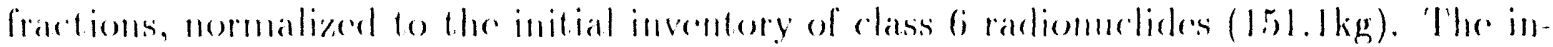
vessed releases are suldelivided inte releases in the "rore" and "lower plemum" regions in

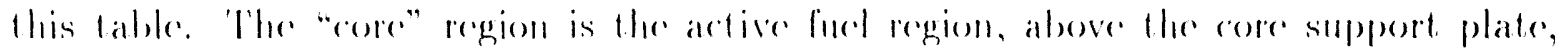

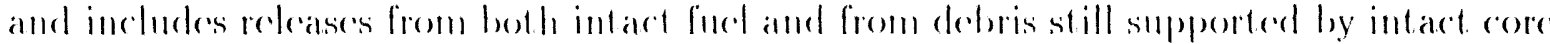
components or by the core suppont plate; the "lower plemum" release is from debris that has fallen through the core support plate and is being held in the lower plenum on the vessed lower head priog lo being lest to the cavity through a lower head failure. There

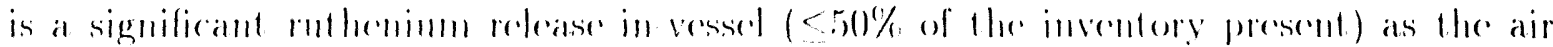
ingression is increased $10.32 .2 \mathrm{~kg} / \mathrm{s}(\sim 100 \mathrm{mos} / \mathrm{s})$, with $280 \%$ of the release in the lower plemem and $20 \%$ in the core. Note that this is the opposite of the pattern seen in the air

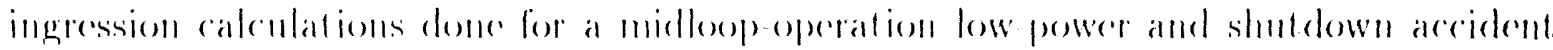

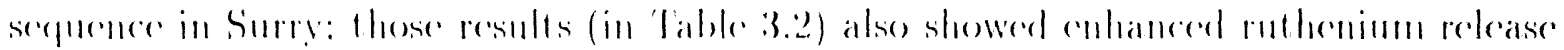

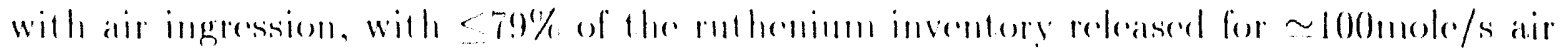
flow, but with $280 \%$ of the release in the core and $\sim 20 \%$ in the lower plenum. With no

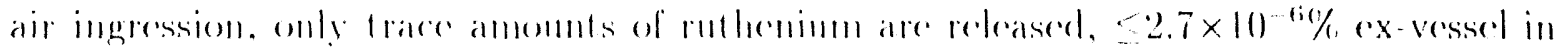

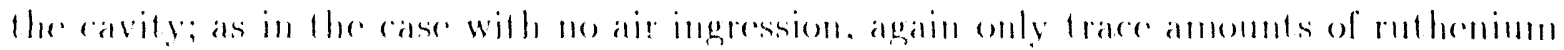

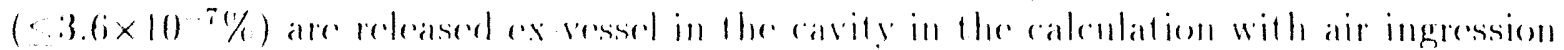
asstmmed.

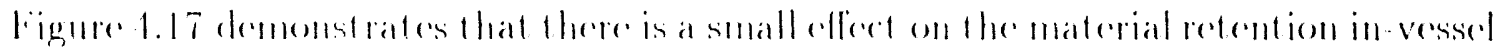

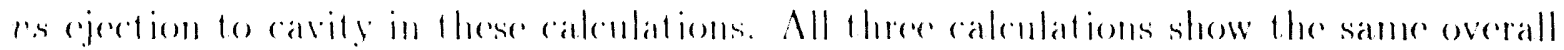

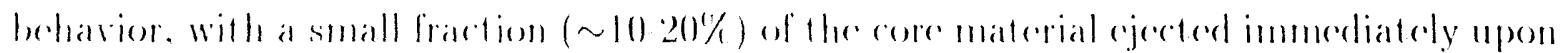

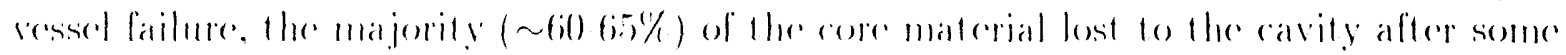

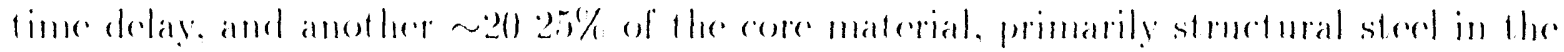

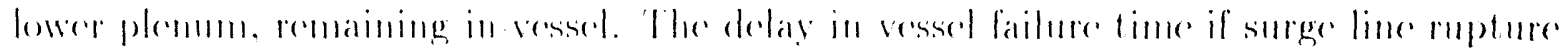

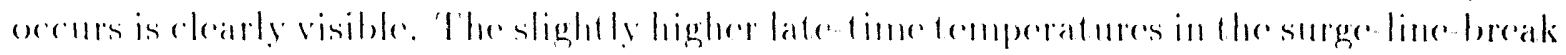
calculation with neserespecitied air ingression inte the core, due to the highere energy of

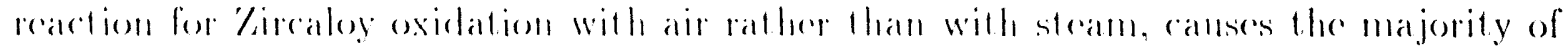
the core material to medt, relocate and be lost to the cavity somer than predieded in the calcolation with a surge line break hut with no user sperilied air ingression into the core.

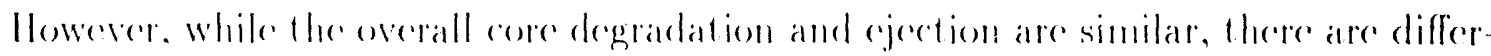

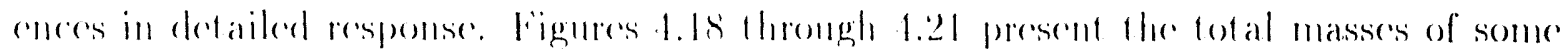

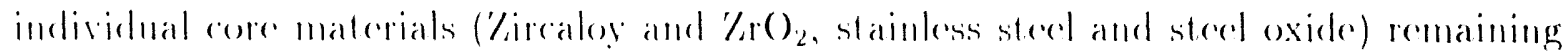
in the vessed. (The individual masses of le( $)_{2}$ fure and rontrol rod poison are not given, beranse they stow lithlo or no dependenere on air ingression; instearl, in all rases the

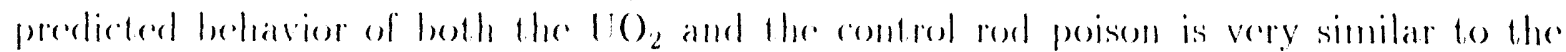

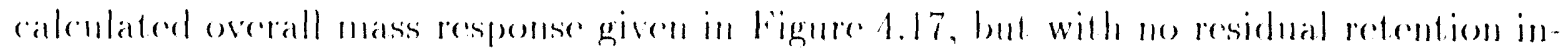

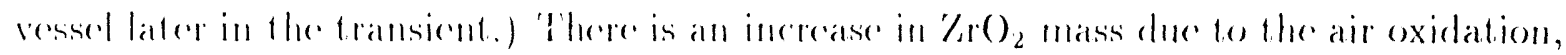

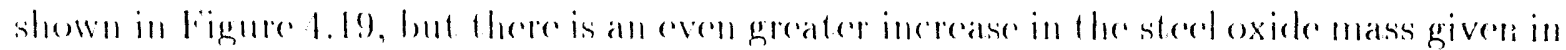

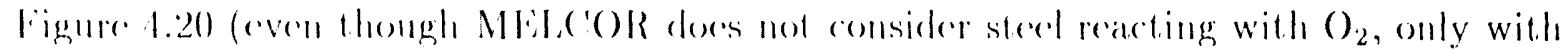
steam); this represents the increased avalability of steam to oxidize the steed because 


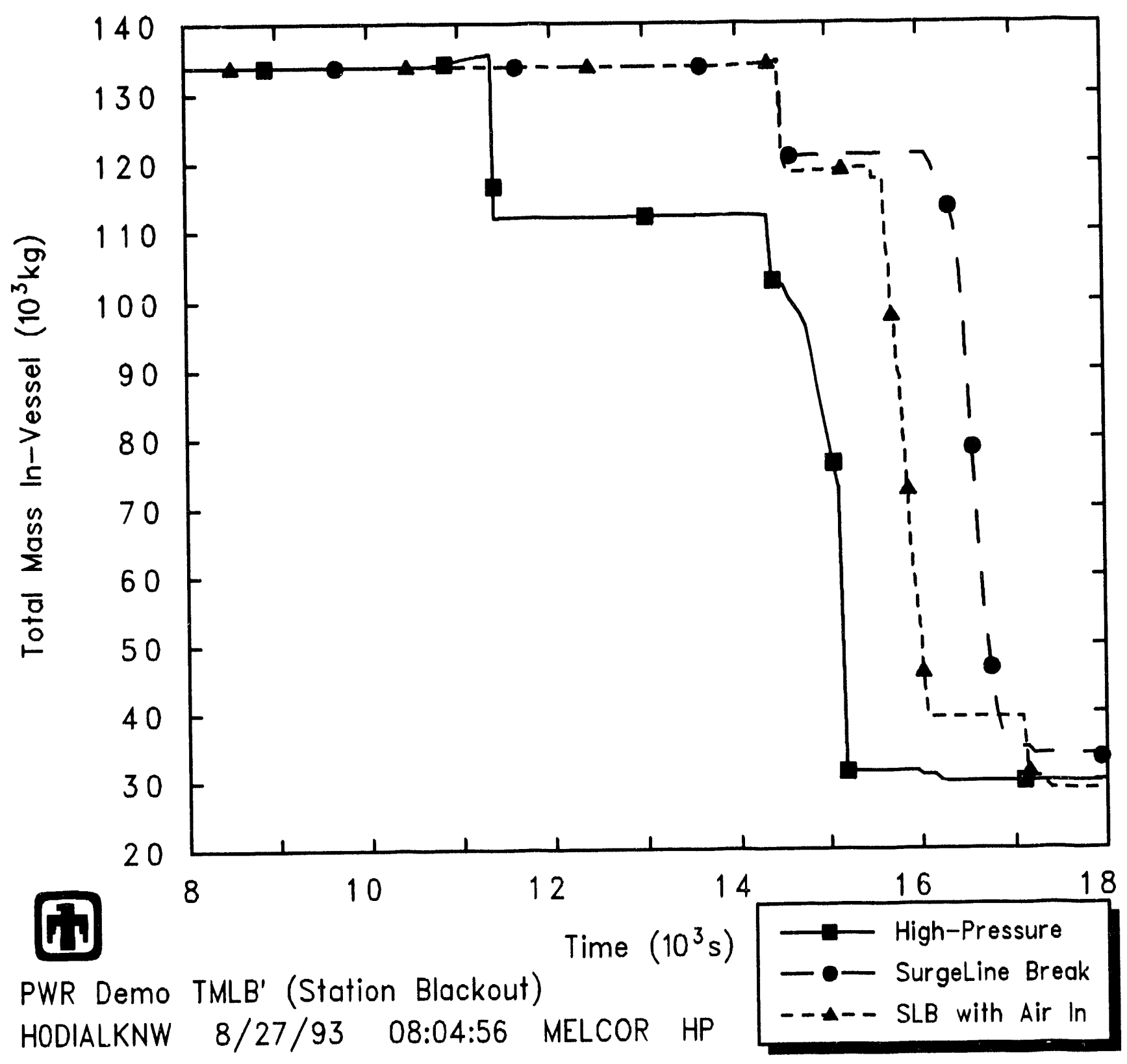

Figure 4.17. Total Core Masses in MELC COR Surry 'TMLB' Calculations with Surge Line Break and $A$ ir Ingression 
the '/ircaloy is being oxidized preferentially with the oxygen introduced. 'The increase in Zircaloy oxidation with air ingression into the core is not sustained or significant because of the more rapid loss of Zircaloy from the vessel to the cavity in the surge-line-break calculation with user-sperified air ingression into the core, discussed above.

Table 4.3 presents the total amount of oxygen in the air ingression, the amounts of oxygen and steam consumed in-core by oxidation reactions, the amount of hydrogen produced in-vessel through metal reaction with steam, and the total oxidation energy. (Note that the amomit of steam consumed in oxidation, the amount of hydrogen produced and the total oxidation energy include Zircaloy oxidation with steam prior to the specified air ingression, in addition to Zircaloy reaction with oxygen, as well as oxidation of core and lower plenum structural steel with steam throughout the transient period calculated; there is currently no provision in MEle(')R to edit the Zircaloy and steel oxidation reartions separatcly.)

Overall, about $15 \%$ of the total oxygen sourced into the core as part of the air ingression between $\geq 11,500 \mathrm{~s}$ and $30,000 \mathrm{~s}$ is consumed in Zircaloy oxidation; however, since most of the in-vessel oxidation occurs over a much shorter time period ( $14,000 \mathrm{~s}-16,000 \mathrm{~s})$, the actual fraction of oxygen available during that period that was consumed in metaloxidation reactions is much greater $(\geq 75 \%)$. As would be expected, the steam consumption and hydrogen production drop and the oxidation energy rises as more oxygen is consumed, because of the enhanced heat generation from the $\mathrm{Zr}+\mathrm{O}_{2}$ reaction ves reaction with steam.

The assumed air ingression has the greatest effect on the ruthenium release, but also a smaller effect on the release for other radionuclides. Table 4.4 gives the in-vessel releases as a percentage of initial inventory present, calculated for other radionuclide classes. Note that, with the (ORSOR-M option used, there is no in-vessel release of ('lass 7 (the early transition clements, represented by Mo), (lass 9 (the trivalents, represented by laa) or ('lass 11 (the more volatile main group elements, represented by ('d). As the rate of air ingression assumed is increased, there is a small increase ( $23 \%)$ in the release fractions of the volatiles (i.e., the noble gases, the alkali metals represented by ('s and the halogens represented by 1); there is also a similar small increase in the release fraction of the chalcogens, represented by 'Te, and apparently very little holdup in unoxidized Zircaloy clad in any case. These small increases in release probably reflect the enhanced clad/fuel heatup from the $/ \mathrm{r}+\mathrm{O}_{2}$ reaction. In contrast, small decreases in release fraction are seen for the alkaline carths, represented by Ba, and the less volatile main group elements, represented by $\mathrm{Sn}$, both of which are intermediate in release $(\sim 1 \%)$ between the volatiles $(\leq 100 \%$ release) and the refractories ( $\ll 1 \%$ release), as well as in the trace amounts of refractories released, for both the tetravalents represented by (e and for uranium, in the ralculations with air ingression assumed; this is probably due to the cooling effect of the air ingression on the core debris. 


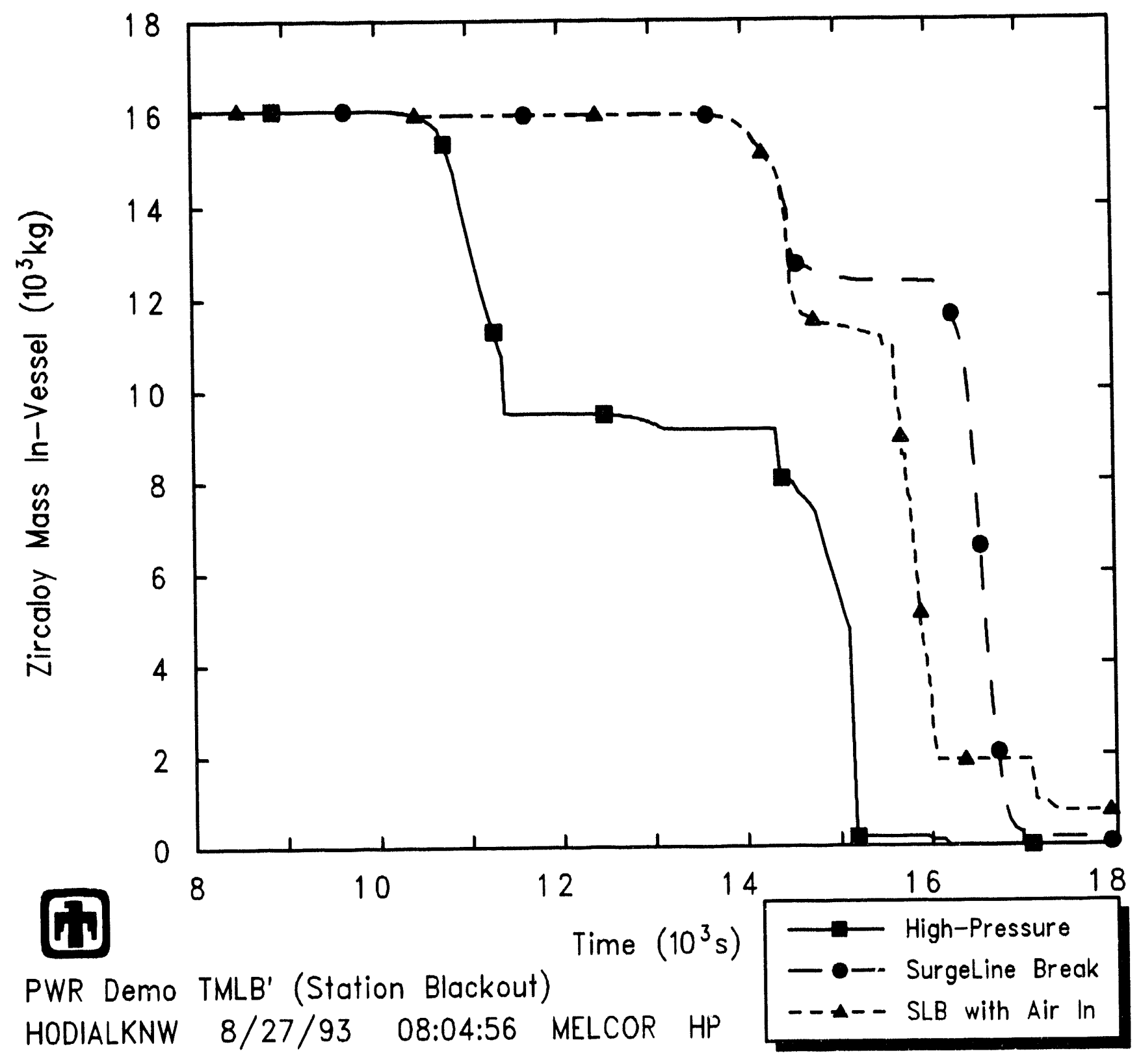

Figure 4.18. Core Zircaloy Masses in MELCOR Surry 'T'MLIB' ('alculations with Surge Line Break and Air Ingression 


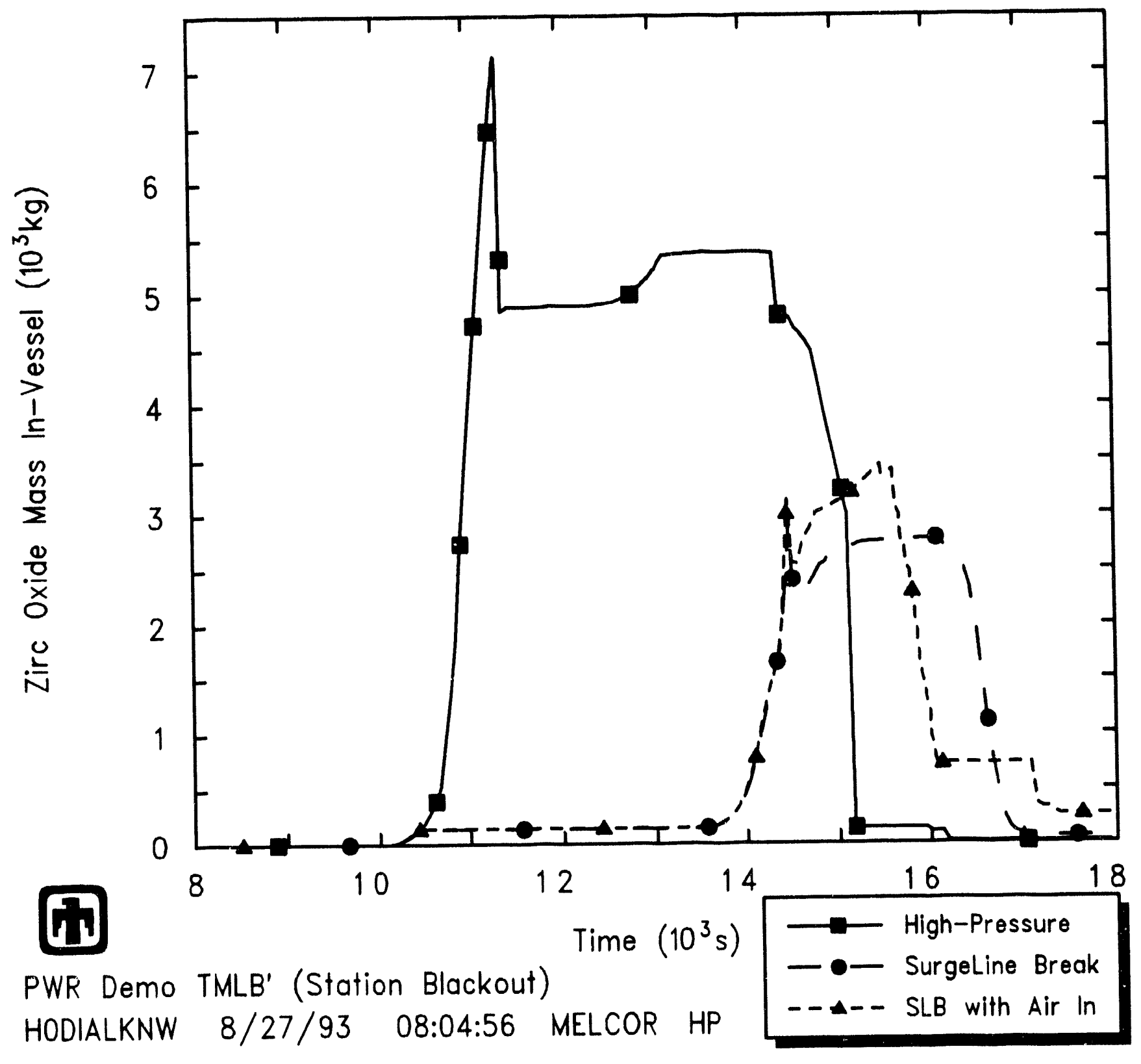

Figure 4.19. ('ore Zirconium Oxide Masses in MEL('OR Surry 'TMLB' Calculations with Surge line Break and Air lngression 
แo!ssomsu d! p pue yеว.lg ou!t

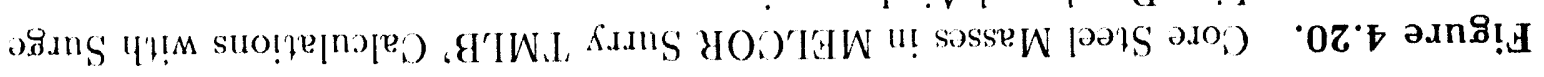

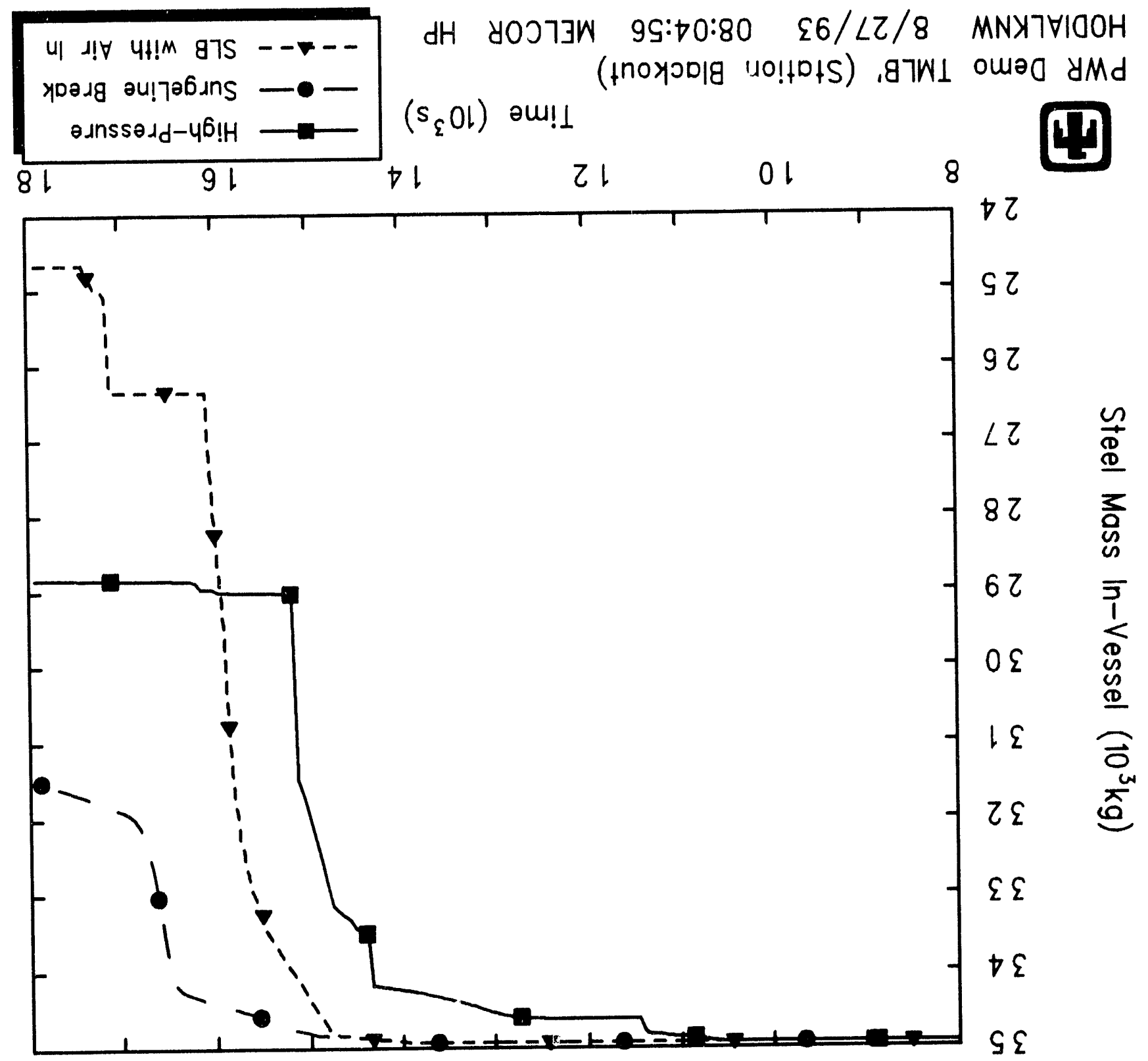




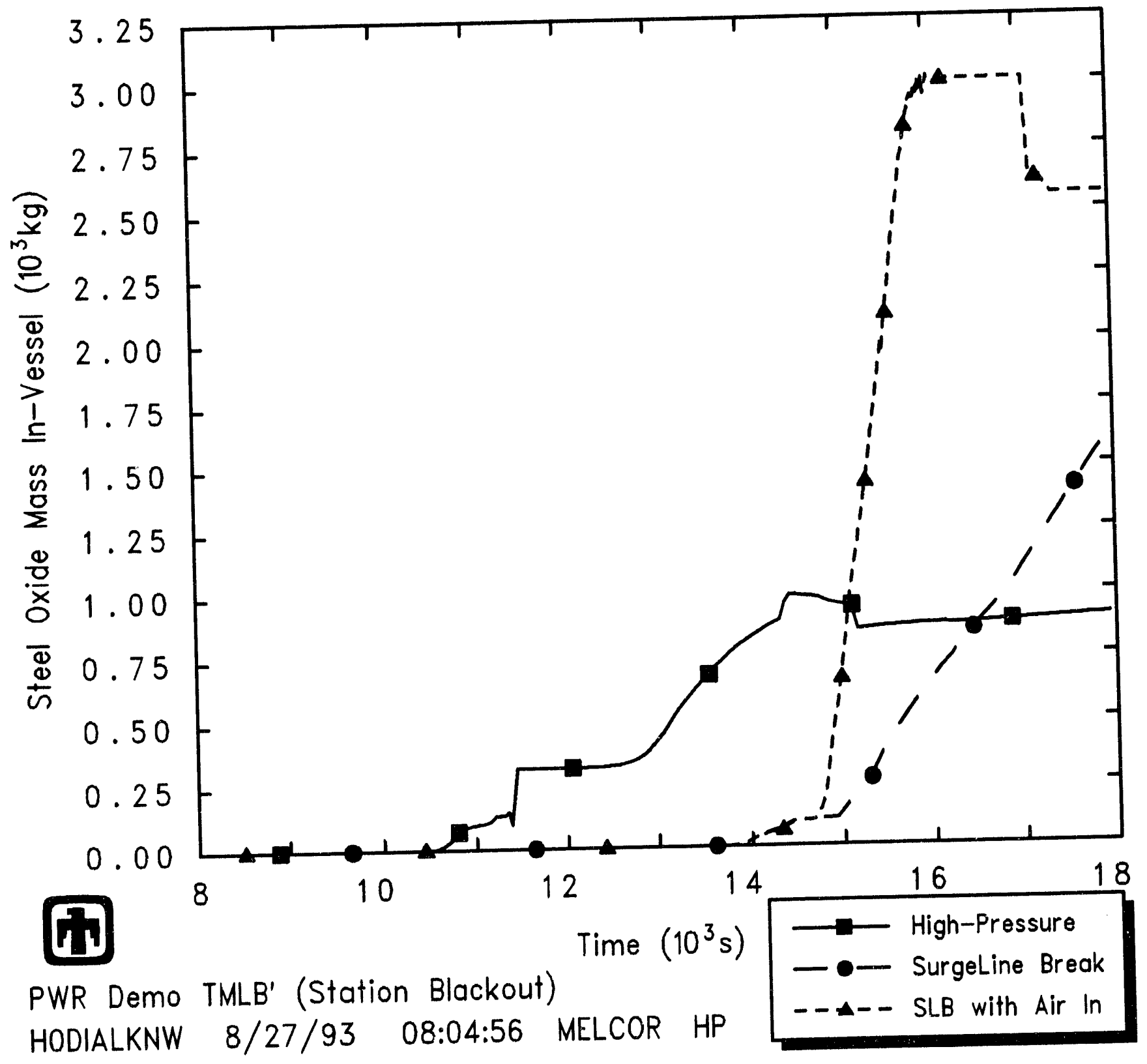

Figure 4.21. Core Steel Oxide Masses in MELCOR Surry TMLB' Calculations with Surge Line Break and Air Ingression 
Table 4.2. In-Vessel Ruthenium Release in MELC'OR Surry TMLB' Calculations with Surge Line Break and Air Ingression

\begin{tabular}{cc|ccc}
\multicolumn{2}{c}{$\begin{array}{c}\text { Air Ingression } \\
\text { Rate }\end{array}$} & \multicolumn{3}{c}{$\begin{array}{c}\text { In-Vessel Release } \\
\text { (\% Initial Inventory) }\end{array}$} \\
\begin{tabular}{cc|ccc}
$(\mathrm{kg} / \mathrm{s})$ & $(\mathrm{mole} / \mathrm{s})$ & Core & Lower Plenum & Total \\
\hline 0 & 0 & 0 & 0 & 0 \\
3.2 & $\simeq 100$ & 9.8 & 40.1 & 49.9
\end{tabular}
\end{tabular}

Table 4.3. In-Vessel Oxidation in MELCOR Surry 'T'MLB' Calculations with Surge Line Break and Air Ingression

\begin{tabular}{|c|c|c|c|c|c|}
\hline \multicolumn{2}{|c|}{ Air Ingression } & \multicolumn{2}{|c|}{ Consumed in Oxidation } & \multicolumn{2}{|c|}{ Produced in (Oxidation } \\
\hline $\begin{array}{c}\text { Flow Rate } \\
\text { (mole/s) }\end{array}$ & $\begin{array}{c}\text { Total } \mathrm{O}_{2} \\
(\mathrm{~kg})\end{array}$ & $\begin{array}{c}\text { Oxygen } \\
(\mathrm{kg})\end{array}$ & $\begin{array}{l}\text { Sicam } \\
(\mathrm{kg})\end{array}$ & $\begin{array}{c}\text { Hydrogen } \\
(\mathrm{kg})\end{array}$ & $\begin{array}{c}\text { Encrgy } \\
(\mathrm{MJJ})\end{array}$ \\
\hline 0 & 0 & 18.14 & 3085 & 34.5 .2 & 24,132 \\
\hline$\simeq 100$ & $5,8.33$ & 813.1 & 2319 & 259.4 & 40,288 \\
\hline
\end{tabular}

Table 4.4. In-Vessel Radionuclide Release in MLL('OR Surry 'TMLB' ('alculations with Surge Line Break and Air Ingression

\begin{tabular}{|c|c|c|c|c|}
\hline \multirow[t]{2}{*}{$\begin{array}{c}\text { Air Ingression } \\
(\text { mole/s })\end{array}$} & \multicolumn{4}{|c|}{$\begin{array}{l}\text { In-Vessel Release } \\
(\% \text { Initial Inventory) }\end{array}$} \\
\hline & Class 1 (Xe) & Class 2(Cs) & Class 4 (I) & (Jass 5 (To) \\
\hline 0 & 46.12 & 46.10 & 46.09 & 45.93 \\
\hline$\simeq 100$ & 49.14 & 49.13 & 49.11 & 48.97 \\
\hline & (Jass $3(\mathrm{Ba})$ & ()$_{\text {ass }} 8((\mathrm{c})$ & ('Jass $10(U)$ & (')ass $12(\mathrm{Sn})$ \\
\hline 0 & 0.6125 & $2.544 \times 10^{-4}$ & $2.568 \times 10^{-2}$ & 1.939 \\
\hline$\simeq 100$ & 0.1488 & $1.817 \times 10^{-5}$ & $3.0331 \times 10^{-3}$ & 0.848 \\
\hline
\end{tabular}




\section{MELCOR Grand Gulf Low-Power/Shutdown Cal- culations with Air Ingression}

As part of a separate, ongoing program provirling MELCOR support calculations for the Cirand (iulf low-power/shutdown PRA [11], two calculations were done to address concerns about air oxidation and the associated chlanced release of ruthenium expected to occur when irradiated reactor fued is heated in air. In both, the effect of oxidation with free oxygen in addition to the oxygen in stean was included in the code; in one calculation a constant release rate coefliciont was used for ('lass 6 (Ru), greater than the default (OORSOR-M value (Fe. $2.4 \mathrm{in}$ Section 2), while the other calculation used a variable coefficient dependent on the partial pressure of oxygen in the core (Eq. $2.3 \mathrm{in}$ Section 2).

(While these Girand Gulf MELCOR calculations were not done as part of the air ingression analysis effort reported on in this report, they investigated the same issues and cvaluated the same accident conseguences, and came to basically the same conclusions. Because those calculations will not be formally documented until the completion of that PRA program, the NRe' contract monitor for that program has graciously agreed to allow us to include a brief summary of those (alculations and results in this report.)

These Cirand Ciulf air-ingression calculations assume the plant to be in POS6, a condition occurring during the early portion of the refueling mode of operation. 'This state is the BWR analogue of the POSG mid-loop operation modelled for the Surry lowpower and shutdown air ingression accidents analyzed in Section 3. For a BWR, POS 6 begins when the vessel head is detached and ends when the upper reactor cavity has been filled with water. 'llie carliest the plant enters this mode of operation is typically four days after shutrlown. In this POS both the drywell head and the vessel head have been removed and the containment hateh and persomnel locks are open; the drywell equipment hateh also is open. 'Thus, both the vessel and the drywell communicate directly with the containment (i.e. the suppression pool is effectively bypassed) and the containment is open to the anxiliary building. Dnring this POS the steam dryers are removed and the steam lines are plugged. 'The suppression pool can be either at its normal operating level, partially drained or completely empty. Furthermore, the suppression pool makeup system has been isolated; therefore the suppression pool cannot be used as a continuous supply of water for cither core cooling or the containment sprays. [23, 24]

The (irand (fulf low-power/shutdown calculations done predict no oxygen to be drawn into the core until late in the transient, after the core material has fallen into the cavity. To investigate the impact of air oxidation and enhanced ruthenimm release, we had to externally introduce oxygen directly into the core control volume. A total of $28,608 \mathrm{~kg}$ of $\mathrm{O}_{2}$ (the amomint that would be required to oxidize all the clad in the core), was added into the core control volume starting when the core liquid level drops below the top of the active fuel until a lower hear penetration first fails (i.e., from 13.04hr to 18.76hr); the oxygen was added at a minform rate of $\sim 1.4 \mathrm{~kg} / \mathrm{s}$ which is $\sim 44 \mathrm{~mole} / \mathrm{s}$. 
Table 5.1. Oxidation Masses for Grand Gulf Low-Power/Shutdown Calculations with Air Ingression

\begin{tabular}{|c|c|c|c|}
\hline Material & $\begin{array}{l}\text { Total Ma } \\
\text { No Air-Ox }\end{array}$ & $\begin{array}{l}\text { sse's at End of 'Tra } \\
\text { Constiant Coeft. } \\
\text { (Eq. 2.4) }\end{array}$ & $\begin{array}{l}\text { msient (kg) } \\
P\left(\mathrm{O}_{2}\right) \text { Cocff. } \\
(\mathrm{Eq} \cdot 2.3)\end{array}$ \\
\hline \multicolumn{4}{|l|}{ In COR Package } \\
\hline Zircaloy & 12356 & 24551 & 6818 \\
\hline Zirc Oxide & 7211 & 7890 & 8784 \\
\hline Stainless Steel & 35299 & 35875 & 33650 \\
\hline Steel Oxide & 1809 & 1688 & 3658 \\
\hline Steam Consumed & 8750 & 3078 & 5738 \\
\hline Oxygen Consumed & & 4862 & 6291 \\
\hline \multicolumn{4}{|l|}{ In CAV Package } \\
\hline Metal Layer & 83959 & 7746 & 87965 \\
\hline (Light) Oxide Layer & 591150 & 413250 & 618710 \\
\hline \multicolumn{4}{|l|}{ Hydrogen } \\
\hline Produced in Vessel & 1001 & 344 & 642 \\
\hline Produced in Cavity & 1280 & 1019 & 1159 \\
\hline Total Produced & 2281 & 1363 & 1801 \\
\hline
\end{tabular}

There is no difference in timing on any events before the extra oxygen is first sourced in. The gap release and the failure of the lower head penetrations in the various rings are predicted to occur somewhat earlier, because of the slightly accelerated core heatup due to more clad oxidation. There are no major differences observable in primary and containment systems pressure histories, or core inventory boiloff. Clad temperature histories in the core level just below the active fuel midplane in one of the six core rings are presented in Figure 5.1, as representative of the overall core response. The two airoxidation sensitivity study calculation, both show more rapid clad heatup due to the increased degree of (exothermic) clad oxidation, resulting in earlier melt, relocation and lower head failure.

The masses of Zircaloy and $\mathrm{ZrO}_{2}$, stainless sterl and steel oxide, steam and oxygen consumed and hydrogen generated by the end of these transient calculations are presented for these air-oxidation sensitivity studies in Table 5.1. With the free oxygen source, 10 $20 \%$ more Zircaloy and 100\% more steel is oxidized in-vessel. Because $30-60 \%$ less steam 


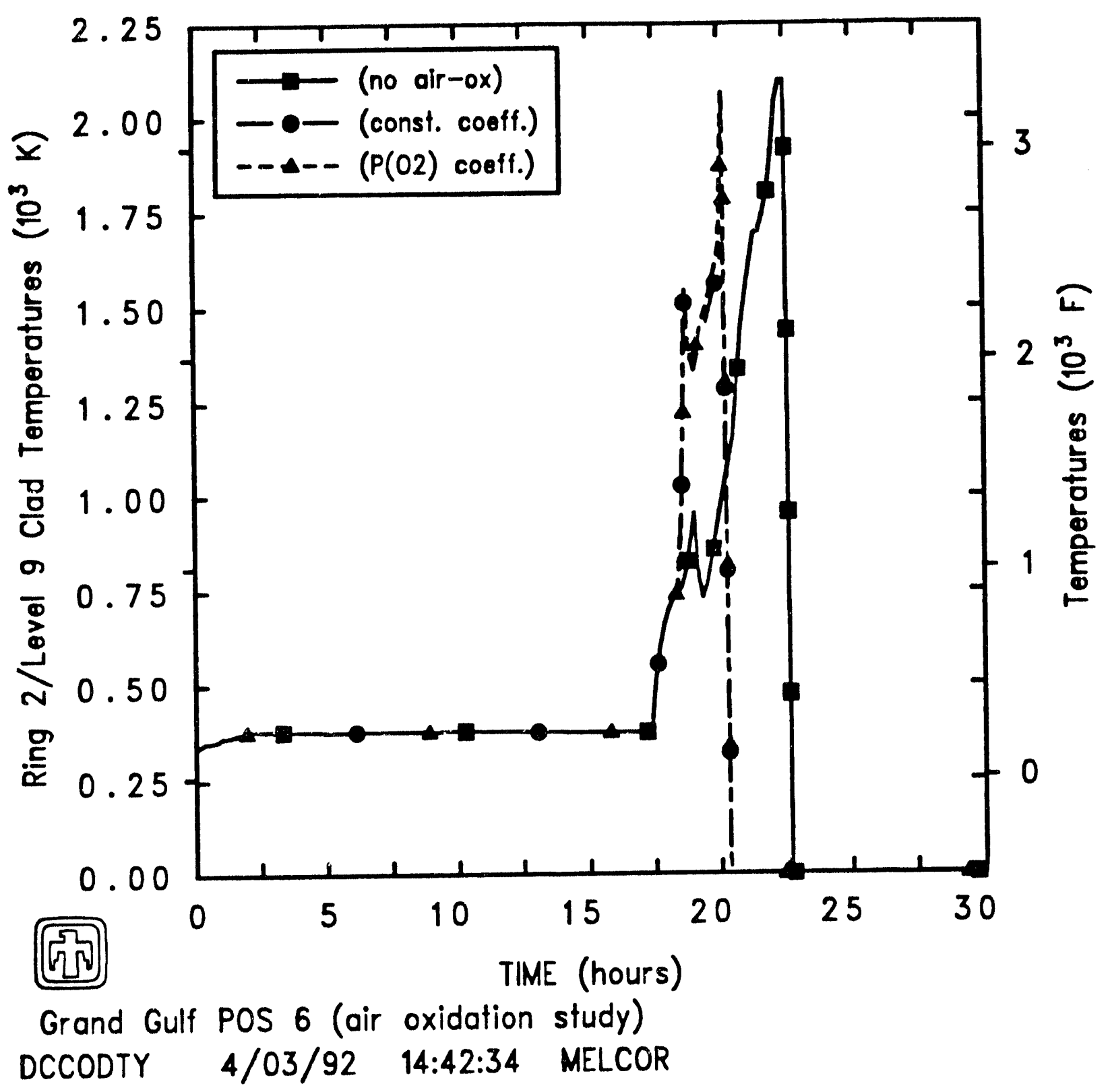

Figure 5.1. Irevel 9 ('lad limperatures for Cirand (iulf low-Power/Shutrdown (alculations with Air Ingression 
is consumed, 30-60\% less hydrogen is generated in-vessel; with 10-20\% less hydrogen generated in the cavity, the total amount of hydrogen generated is $20-40 \%$ less in the two air oxidation sensitivity studies. The lower amounts of hydrogen produced in the air oxidation sensitivity studies are primarily a result of sharp differences during the time period the frec oxygen is being added, not gradual divergences throughout the remainder of the transient. (Most of the oxygen soureed inte the core control volume therefore escapes out through the upper head and vessel breach, to the containment and then the enviromment, without being consumed in oxidation processes.)

Table 5.2 compares the masses of radionuclides released in this set of MEL('()R calculations, when a lower head penetration first fails and at the end of the calculation (i.e., when the cavity is predieted to rupture), normalized to the initial masses of each class. The primary difference is the (as expected) $\simeq 100 \%$ release of ruthenium in-vessel in the wo air-oxidation sensitivity study analyses, both using a constant release rate coefficient and using a variable coefficient dependent on the partial pressure of oxygen in the core. But there are other differences. Circater amounts of the more refractory classes (Ba, Ce, I and Sn) are relcased prior to vessel breach in the two air-oxidation sensitivity study calculations; unexpectedly, while more of the more volatile classes (Xe, ('s, I and Te) are released using a constant Ru release rate coefficient, slightly less are relased using a variable Ru release coefficient dependent on the partial pressure of oxygen in the core than predicted with no air oxidation at all.

The comparison of released radionuclides by the time of cavity rupture is more confused. The three classes with identically-zero in-vessel releases all show the greatest release fraction for the air-oxidation sensitivity study using a constant release coefficient for Class 6; the other more refractory classes (Ba, (Ce, I and Su) show higher release in the calculation with a variable Ru release coefficient dependent on the partial pressure of oxygen; the volatiles (Xe, ('s, I and $T$ C) all show 90-100\% releases with no clare pattern of variation.

The radioactive masses released from the fuel and debris for cach class, and the amount released to the environment by the time of cavity rupture (given in terms of the initial inventory) also are summarized in Table 5.2 . Most (>50\%) of 1 he $\sim 100 \%$ rutheniun released in the two air-oxidation sensitivity stmdy analyses escapes to the environment (in the absence of any additional retention in the anxiliary building, not. included in these calculations). 
Table 5.2. Fission Produrt Roleass Masses for Cirand (Bulf Low-Power/Shutdown (alculations with Air Ingression

\begin{tabular}{|c|c|c|c|c|c|c|}
\hline \multirow{3}{*}{ ('Iasss } & \multicolumn{6}{|c|}{$\begin{array}{l}\text { Radionuclides Released } \\
\text { (1/\% of Initial Inventory) }\end{array}$} \\
\hline & \multicolumn{3}{|c|}{ Before Vessed Breach } & \multicolumn{3}{|c|}{ Before (avity Rupture } \\
\hline & No $\Lambda$ ir & $\begin{array}{l}\text { Const. Coeff. } \\
\text { (1ip. } 2.4)\end{array}$ & $\begin{array}{c}P\left(\mathrm{O}_{2}\right)(\text { 'offt. } \\
(\mathrm{Ha} \cdot 2.3)\end{array}$ & No $A$ ir & $\begin{array}{c}\text { Const. Coeff. } \\
\text { (lig. 2.4) }\end{array}$ & $\begin{array}{c}P\left(\mathrm{O}_{2}\right) \text { Goeff. } \\
(\mathrm{Eq} \cdot 2.3)\end{array}$ \\
\hline $1\left(X_{0}\right)$ & 81.3 & 93.2 & 79.5 & 100.0 & 97.7 & 100.0 \\
\hline $2((s)$ & 81.7 & 93.3 & 79.9 & 100.0 & 97.9 & 100.0 \\
\hline $3(\mathrm{Ba})$ & 2.38 & 8.65 & 22.1 & 42.0 & 12.7 & 47.1 \\
\hline $4(1)$ & 81.0 & 93.1 & 79.2 & 95.5 & 93.4 & 89.0 \\
\hline $5(10)$ & 72.5 & 92.6 & 76.3 & 95.2 & 95.8 & 92.8 \\
\hline $6(R u)$ & 0.00002 & 99.9 & 100.0 & 0.0070 & 100.0 & 100.0 \\
\hline $7(\mathrm{Mo})$ & 0.0 & 0.0 & 0.0 & 1.61 & 3.23 & 1.405 \\
\hline $8((c)$ & 0.0000003 & 0.0074 & $0.11 \times 6$ & 0.0037 & $0.00 \times 2$ & 0.1276 \\
\hline $9(1 ; a)$ & 0.0 & 0.0 & 0.0 & 0.2170 & 0.6666 & 0.3588 \\
\hline $10(1)$ & 0.00156 & 0.520 & 4.59 & 1.62 & 0.522 & 5.10 \\
\hline $11((d)$ & 0.0 & 0.0 & 0.0 & 0.03855 & $0.08(0) 8$ & 0.0763 \\
\hline $12(\sin )$ & 2.866 & 19.3 & 28.0 & 22.5 & 20.7 & 34.8 \\
\hline \multirow[t]{2}{*}{ ('lass } & \multicolumn{3}{|c|}{ Roloased Bofore (av-Rupture } & \multicolumn{3}{|c|}{ liscaped to Environment } \\
\hline & No $\Lambda$ ir & $\begin{array}{l}\text { Const. Cooff. } \\
\text { (liq. 2.1) }\end{array}$ & $\begin{array}{c}\mathrm{P}\left(\mathrm{O}_{2}\right) \text { Cooff } \\
(\mathrm{Eg} \cdot 2.3)\end{array}$ & No $\operatorname{Air}$ & $\begin{array}{l}\text { Const. Coeff. } \\
\text { (lig. 2.4) }\end{array}$ & $\begin{array}{c}\mathrm{P}\left(\mathrm{O}_{2}\right) \text { Coeff. } \\
(\mathrm{Eq} \cdot 2.3)\end{array}$ \\
\hline $1(X 0)$ & 100.0 & 97.7 & 100.0 & 100.0 & 97.5 & 100.0 \\
\hline $2((\mathrm{~s})$ & 100.0 & 97.9 & 100.0 & 67.6 & 62.6 & 60.7 \\
\hline $3(13 a)$ & 42.0 & 42.7 & 47.1 & 21.3 & 21.8 & 16.9 \\
\hline$f(1)$ & 95.5 & 93.4 & 89.0 & 95.5 & 93.4 & 88.9 \\
\hline $5\left(T^{\prime}(0)\right.$ & 95.2 & 95.8 & 92.8 & $(i 2.3$ & 60.6 & 47.0 \\
\hline$(j(R u)$ & 0.0070 & 100.0 & 100.0 & 0.0045 & 62.2 & 54.6 \\
\hline$T\left(M_{1}\right)$ & 1.61 & 3.23 & 1.10 .5 & 0.612 & 1.26 & 0.487 \\
\hline$x((c)$ & $0.00: 37$ & $0.00 \times 2$ & 0.1276 & 0.00215 & 0.00467 & 0.0259 \\
\hline $9(\mathrm{l} a)$ & $0.2: 70$ & $0.6666 ;$ & $0.35 \mathrm{k}$ & 0.1024 & 0.365 & 0.168 \\
\hline $10(1)$ & 1.62 & 0.522 & 5.10 & 0.212 & 0.30 .5 & 1.20 \\
\hline $11((d)$ & $0.0) 38.5$ & $0.08(0) \times$ & $0.07(6)$ & $0.0 \mid \times 9$ & 0.0388 & 0.040 \\
\hline $12(\sin )$ & 22.5 & 20.7 & $31 . x$ & 15.5 & 12.5 & 14.3 \\
\hline
\end{tabular}




\section{Conclusions}

'Two sets of MELCOR calculations have been completed studying the effects of air ingression on the consequences of various severe accident scenarios. One set of calculations analyzed a station blackout with surge line failure prior to vessel breach, starting from nominal operating conditions; the other set of calculations analyzed a station blackout. occurring during shutdown (refueling) conditions. Both sets of analyses were for the Surry plant, a three-loop Westinghouse PWR. For both acciclent scenarios, a basecase calculation was done, and then repeated with air ingression from contaimment into the core region following core degradation and vessel failure.

In addition to the two sets of analyses done for this program, a similar air-ingression sensitivity study was done as part of a low-power/shutdown PRA, with results summarized here; that PRA study also analyzed a station blackout occurring during shutdown (refueling) conditions, but for the Grand (iulf plant, a BWR/6 with Mark III containment.

All three studies lead to the ame conclusions. For the two major phenomena dependent on air ingression:

1. There is a significant increase in ruthenium release in-vessel, to $\sim 50-80 \%$ of initial inventory, assuming moderate air ingression rates of $\sim 10-100 \mathrm{~mole} / \mathrm{s}$; without any air ingression, only trace amounts of ruthenium are released.

2. There is some increase in elad oxidation degree and energy, but only $\sim 10-20 \%$; most of the oxygen sourced into the core region escapes before it is consumed.

The enhanced ruthenium release with air ingression was expected. 'The relatively small changes in core temperatures, hydrogen production and steam consumption, and oxidation energy were not expected. 'The greater oxidation encrgy due to reaction of Zircaloy

with oxygen does cause core temperatures to rise more quickly than for oxidation only with steam, but those higher temperatures then cause the remainder of the core material to melt, relocate and be lost to the cavity sooner than predicted with no air ingression into the core. Oxidation of Zircaloy with air rather than with steam for the relatively short period of time that the clad remains in-vessel does not significantly affect the overall steam consumption and hydrogen production, and the total oxidation energy, because these are dominated by the long-term oxidation of structural stainless steel in the core and especially in the lower plenum.

The assumed air ingression does not signific antly affect most of the accident scenario. There are some small effects on fission product releases in general:

1. There is very little change in the release of the volatile species, i.e, noble gases, Cs, I and Te, which are released at lower temperatures $(T \leq 2000 \mathrm{~K})$; most of their initial inventory has been released before vessel breach and air ingression. 
2. In most cases, there is a small increase in the releases of those species, i.e., Ba and Sn, requiring somewhat higher temperatures $(2000 \mathrm{~K} \leq T \leq 2500 \mathrm{~K})$ for release, probably reflecting the increased oxilation energies and temperatures from Zircaloy reacting with air.

3. There is usually a decrease in the release of refractory species, i.e., Ce and U, which are released only at very high temperatures $(T>2500-3000 \mathrm{~K})$, possibly due to the cooling effect of sourcing relatively cool containment air into the core region.

These predicted changes in radionuclide release reflect only the effects of air ingression changing the calculated core temperatures and relocation history. There may be other, larger changes in fission product release with air ingression, if other species are also sensitive to the oxygen potential as is ruthenium; however, any such additional effects air could have on the release and transport characteristics of other radionuclides were not modelled for these initial calculations.

These studies help quantify the amount of air that would have to enter the core region to have a significant impact on the severe accident scenario. These calculations demonstrate the potential of air ingression to substantially cnhance ruthenium release. These analyses indicate no substantive increases in maximum core temperatures, albeit with modest acceleration of the core degradation process, due to the increased heat of reaction of Zircaloy oxidized by air rather than by steam. 


\section{Bibliography}

[1] M. Donahue, M. Hazzan, J. Motcalf, F. Warman, "Analysis of Retention/Revaporization in a Mark II Power Plant", Procerdings, International Symposimm on Source 'Term Evaluation for Accident ('onditions, ('olumbus. Ohio, October 28-November 1, 1985 (published by MEA, Viemar. 1986), pp. 279-292.

[2] A. S. Benjamin, D). J. Ma('loskey D). A. Powers, S. A. Dupree, "Spent Fuel Heatup

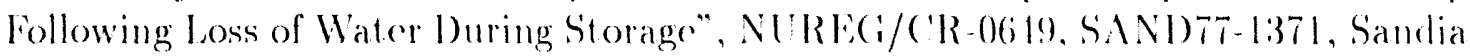
National Lahoratory, Marrh 1979.

[3] F. ('. Iglesias, ('. E. L. Ilunt, F. (Baristo, D). S. ('ox, "Mcasured Release Rinetices of Ruthenium from Iranium Oxirles in Air", Procecelings. International Seminar on Fission Products Transport Processes During Roactor Acrirlonts, Dubrovnit, Yugoslavia, May 1989.

[4] F. Ciaristo, F. ('. Iglesias, ( . E. L. Hunt, "A Thermodynamic/Mass-Transport Modol for the Release of Ruthenium from Irtadiated Fuel", Proceedings, International Sem. inar on Fission Products Transport Processes 1)uring Reactor Accidents, Dubrovinik. Yugoslavia, May 1989.

[5] R. Williamson, S. A. Beetham, "Fission Product Release During the Air Oxidation of Irradiated Uranium Dioxide", Proceedings, Intermational Seminar on Fission Products Transport Processes During Reactor Accidents. Dubrovnili, Yingoslavia, May 1989.

[6] C. J. Shaffer, L. A. Miller, A. ('. Payne, Jr., "Integrated Risk Assessment for the LaSalle Unit 2 Nuclear Power Plant: Phenomenology and Risk l'nertainty Evalu-

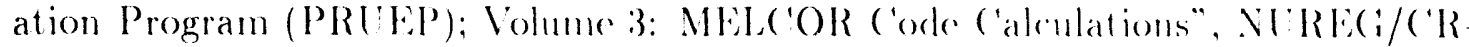
5305, SAND90-2765, Sandia National Laboratories. ()otober 1992.

[7] L. N. Kmetyk, L. N. Smith, "Summary of MELC(OR L.S.2 ('alculations for Three

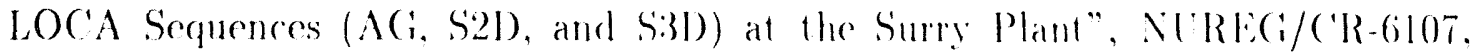
SAN1)93-2012, Sandia National Laboratories, to be publisherl.

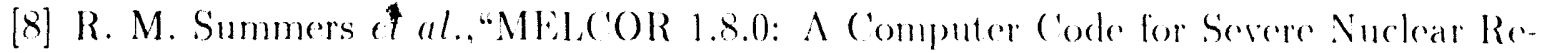
actor Accident Source Term and Risk Assessment Analyses". NlRR(i/c'R-5ji3l. SANI)90-0364, Sandia National Laboratories, Jamuary 19931.

[9] W. Krischer, M. (․ Rubinstein. "The Phebus Fission Product Project". Eilsevior Applied Science ISBN 1851666 i65.52 (1992).

[10] I. Shepherd, A. Jones, (․ Commier, S. Ciaillot, "Phobus-FP: Analy'sis Programmo and Results of Thermalhydraulic 'Tests", Procerdings, 2lst Water Ronctor Safety" Information Mecting, Bethesda MI). ()ctober 25)-17. 19993 (to be published). 
[11] "Simmmary Report of: (Arand Bull Low Power and Shutdown Abridged Risk Analysis; POS 6: Varly Rofucling", Final Ledter Roport from T. D). Brown, SNI, to (: P. Ryder, NR(1, dated October 27, 19993.

[12] R. M. Summers, R. ('. Smith, "Mlil, (O)R core (c)R Parkage Reference Mamual", Sandia National Laboratories, draft dated March 17, 1993.

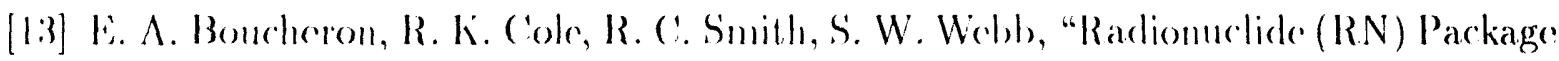
Roference Mamual", Sandia National Laboratories, draft dated fobruary 25, 1993.

[11] M. R. Kuhlman, 1). J. Ichmicke, R. O. Meyer, "(yORsolr Iser's Manual", NItRlici/('R-4173, BMI-2l22, Battelle Memorial Institute, March 1985.

[15] M. Ramammethi, M. R. Kuhlman, "Final Report on Refincment of ('ORSOR An Empirical In-Vessed lission Product Release Model", Battelle Memorial Institute, ()ctobre 31, 1990.

[16] "(')RSOR Release ('ocflicients for Ruthenium in Air", Memo from D). A. Powers, SNI, to li. 'T. IIarper, SNI, dated March 30, 1992.

[17] Private communication, B. Ilolmes, BNI, to I. N. Kinctyk, SNI, May 11, 1993.

[18] L. N. Kmetyk, "MEL('OR 1.8.2 Assessment: Sury PWR 'TMLB" (with a DOCH Study)", $S A N D 93-1899$, Sandia National Labotatories, to be published.

[19] 'T.- L. ('hu et al., "Status of the Pressurized Water Reactor low Power and Shutdown Acrident Freguencies Progrann", Procecedings, International Topical Mecting On Probabilistic Safoty Assessment, PSA Y3, ("loarwater Boach, Florida, January $2(i-29,19993$.

[20] J. Jo (l al., "Risk Analyses of Releases from Accidents during Mirl-Loop Operation at Surry", Proceedings, Intermational Topical Meeting on Probabilistic Safoty Assessment, PSA 93, ('learwater Beach, Floricla, Jannary 26-29, 1993.

[21] J. Jo el al., "Analysis of Acridents during Mid-Joop Operating State at a PWR", NURlaci/c'P-0)26, Procerdings, 20th Water Reactor Safoty Information Meeting, Berhesda, Maryland, (October 21-23, 1992 (published, March 1993)

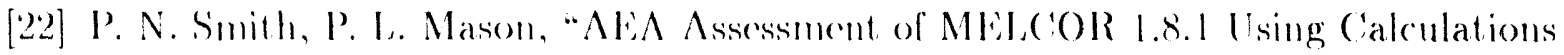

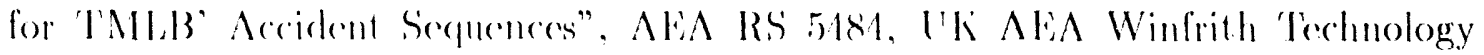
contre. March 1993.

[2:3] 'T. 1). Brown, L. A. Millor, "Abridged Risk Analysis of a Selected Regime of Shutdown for the Cirand Ciulf Nuclear Power Plant", Procededings, luternational Topical Merting on Probatilistic Safoty Assessmont, PSA 93, ("earwater Beach, Florida, Jantary 26-29, 19933. 
[21] 'T. 1). Brown, L. A. Miller, L. N. Kimetyk, "Summary of An Abridged Assessment of Shutdown Risk for a Mark 111 Boiling Water Reactor", NU!RLCi/C'P-0126, Procecelings, 20th Water Reactor Safety luformation Meeting, Bethesda, Maryland, October $21-23,1992$ (published, March 19!13) 
External Distribution:

U. S. Nuclear Regulatory Commission (19)

Attn: S. Acharya, NLS-372

Y. S. Chen, NLN-344

M. A. Cunningham, NLS-372

F. Eltawila, NLN-344

R. B. Foulds, NLN-344

(.) Gingrich, NLN-344

(. (i. Tinkler, NLN-344

S. Basu, NLN-344

A. Behbahani, NLN-344

R. Y. Lee, NLN-344

L. E. Lancaster, NLS-372

R. O. Meyer, NLS-007

J. A. Mitchell, NLSS-314

(. P. Ryder, NLS-372

L. Soffer, NISS-324

B. Sheron, NLS-007

J. A. Murply, NLS-007

L. M. Shotkin, NLN-353

N. Lauben, NLN-353

R. Landry, NLN-344

Washington, DC 20555

U. S. Department of Energy

Attn: P. Worthington, EHI-12

1990I Germantown Road

Germantown, MI) 20585

S. Y. Chen

Argonne National Laboratory

9700 South Cass Avenue

Argonne, IL 60439

Battclle Columbus Laboratories (3)

Attn: P. Cybulskis

M. Carmel

R. S. Denning

505 King Avenue

Columbus, OH 43201 
Battelle Memorial Institute

Attn: C. A. Alexander

505 King Avenue

Columbus, OH 43201

Brookhaven National Laboratory (2)

Attn: I. K. Madni

T. Pratt

Bldg. 130

32 Lewis

Upton, NY 11973

Idaho National Engineering Laboratory (7)

Attn: A. Brown

R. J. Dallman

D. W. Golden

S. E. Reed

G. W. Johnsen

D. Petti

D. Hobbins

EG\&G Idaho

P. O. Box 1625

Idaho Falls, ID 83404

D. Jones

EI International

P. O. Box 50736

Idaho Falls, ID 83405

Electric Power Research Institute (3)

Attn: E. Fuller

R. N. Oehlberg

B. R. Sehgal

P. O. Box 10412

Palo Alto, CA 94303

Los Alamos National Laboratory (2)

Attn: B. E. Boyack, K-551

D. R. Liles, K-553

P. O. Box 1663

Los Alamos, NM 87545 
Oak Ridge National Laboratory (13)

P. O. Box 2009

Oak Ridge, TN 37831-8057

Attn: S. R. Greene, MS-8057

R. H. Morris, MS-8057

S. E. Fisher, MS- 8057

R. Sanders, MS 8057

T. L. Heatherly, MS- 8057

S. A. Hodge, MS-8057

C. R. Hyman, MS- 8057

B. W. Pation, MS-8057

D. B. Simpson, MS-8057

R. P. Taleyarkhan, MS-8057

M. L. Tobias, MS- 8088

T. Kress

A. Wright

P. O. Box 2009

Oak Ridge, TN 37830

Andrzej Drozd

Nuclear Regulatory Commission

OWFN, MS 8E1

11555 Rockville Pike

Rockville, MD 20852

W. P. Barthold

Barthold \& Associates

132 Seven Oaks Drive

Knoxville, TN 37922

K. C. Wagner

Science Applications Intl. Corp.

2109 Air Park Rd. SE

Albuquerque, NM 87106

Savannah River Laboratory (2)

Attn: B. DeWald

D. Allison

Westinghouse Savannah River Co.

Bldg. 773-41 A

Aiken, SC 29808-0001 
Westinghouse Hanford Co. (2)

Attn: D. Ogden

O. Wang

P. O. Box 1970

Richland, WA 99352

General Electric Company (3)

Knolls Atomic Pwer Laboratory

Attn: D. F. McMullan

G. H. Epstein

E. Mennard

Bldg. F3, Room 8

P. O. Box 1072

Schenectady, NY 12301-1072

Bettis Atomic Power Laboratory (3)

Attn: Mark Riley

Jow Semanchik

Vincent Baiamonte

P. O. Box 79

West Mifflin, PA 15122

Mohsen Khatib-Rahbar

Energy Research Inc.

P. O. Box 2034

Rockville, MD 20852

V. K. Dhir

2445 22nd Street

Santa Monica, CA 90403

R. Viskanta

Purdue University

Hea: Transfer Laboratory

School of Mechanical Engineering

West Lafayette, IN 47907

Dr. Jim Gieseke

Battelle Memorial Institute

505 King Ave.

Columbus, Ohio 43201 
M. A. Kenton

Gabor, Kenton \& Associates

770 Pasquinelli Drive

Suite 426

Westmont, IL 60559

University of California (2)

Attn: W. H. Amarasooriya

T. Theofanous

ERC-CRSS

Santa Barbara, CA 93106

F. E. Haskin

University of New Mexico

Department of Chemical and Nuclear Engineering

Albuquerque, NM 87131

University of California, Los Angeles (4)

Nuclear Energy Laboratory

Attn: I. Catton

D. Okrent

W. Kastenberg

G. Apostolakis

405 Hilgaard Avenue

Los Angeles, CA 90024

J. C. Lee

University of Michigan

Dept. of Nuclear Engineering

Cooley Building, North Campus

College of Engineering

Ann Arbor, MI 48109-2104

University of Wisconsin (2)

Dept. of Nuclear Engineering

Attn: M. L. Corradini

G. A. Moses

Engineering Research Building

1500 Johnson Drive

Madison, WI 53706 
Ramu K. Sundaram

Manager, LOCA Analysis Group

Nuclear Engineering

Yankee Atomic Electric Company

580 Main Street

Bolton, MA 01740

John Bolin

CEGA

P. O. Box 85608

San Diego, CA 92186-9784

M. Plys

Fauske \& Associates

16W070 West 83rd Street

Burr Ridge, II, 60521

Nick Trikouros

GPU Nuclear Corporation

One Upper Pond Road

Parsippany, NJ 07054

B. Raychaudhuri

Nebraska Public Power District

PRA \& Engineering Review Group

P. O. Box 499

Columbus, NE 68601

Frank Elia

Stone \& Webster Engineering Corp.

245 Summer Street

Boston, MA 02210

Samir S. Girgis

Atomic Energy of Canada Limited

CANDU Operations

Sheridan Park Research Community

Mississagua, Ontario

CANADA L5K1B2 
Paul J. Fehrenbach

Chalk River Nuclear Laboratories

Fuel Engineering Branch, RSR Division

Chalk River, Ontario

CANADA KOJ1J0

Dr. Bohumir Kujal

Department of Reactor Technology

Nuclear Research Institute Řez plc

25068 Řež

CZECH REPUBLIC

Andrej Mitro

Institute of Radioecology and Applied Nuclear Techniques

Garbiarska 2

P. O. Box A-41

04061 Kos̆ice

CHECHOSLOVAKIA

Shih-Kuei Cheng

Institute of Nuclear Energy Research

P. (). Box 3-3

Lung-Tan, Taiwan

REPUBLIC OF CHINA

Technical Research Centre of Finland (3)

Nuclear Engineering Laboratory

Attn: Lasse Mattila

Ilona Lindholm

Esko Pekkarinen

P. O. Box 208 ('Tekniikantie 4)

SF-002151 Espoo

FINI,AND)

Jorma V. Sandberg

Finnish Center Radiation \& Nucl. Safety,

Dept. of Nuclear Safoty

P. O. Box 268

SF-00101 Helsinki

FINLAND) 
CEA/Cadarache/Semar (10)

Attin: M. Arnaud

M. Agroguer

M. Mailliat

M. Serre

M. Hidaka

M. Park

Mme. S. Dickinson

M. Dumaz

M. Hueber

M. Wadworth

13108 Saint-Paul-Lez-Durance

FRANCE

CEA/Cadarache/SEA (3)

Attn: M. Clement

M. Gronnier

iMme. Ktorza

13108 Saint-Paul-Lez-Durance

FRANCE

CEA/Cadarache/DRS (3)

Attn: M. R. Zeyen

M. A. Meyer-Heine

M. P. VonderHardt

13108 Saint-Paul-Lez-Iurance

FRANCE

CEA/FAR

Attr: Mme. C. Lecomte

60-68 Av. du G. Leclerc - B. P. 6

92265 Fontenay aux Roses Cedex

FRANCE

Dr. Lothar Wolf

Battelle Institute EV

AM Romerhof 35

D-6000

Frankfurt/Main90

GERMANY 
Gesellschaft fur Anlagen- und Reaktorsicherheit (3)

Attn: Ulrich Erven

Walter Erdinann

Manfred Firnhaber

Schwertnergasse 1

D-5000 Koln 1

GERMANY

Kernforschungzentrum, Karlsruhe (4)

Attn: P. Hofmann

Werner Scholtyssek

Philipp Schmuck

Dr. Sigfried Hagen

P. O. Box 3640

D-7500 Karlsruhe 1

GERMANY

Udo Brockmeier

University of Bochum

Energietechnik

IB-4-128

D-4630 Bochum

GERMANY

K. 1). Hocke

Universtitat Stuttgart IKE

Postfach 1801140

D)-7000 Stuttgart 80

GERMANY

K. Trambauer

Gesellschaft fur Reaktorsicherheit (GRS) mbH

Forschungsgelande

D-8046 Garching

GERMANY

György Gyenes

Central Research Institute for Physics

Institute for Atomic Energy Research

H-1525 Budapest, P. O. Box 49

HUNGARY 
CEC Joint Research Center (4)

Commission of the European Communities

Attn: Alan Jones

Iain Shepherd

Y. Drossinos

J. Capitao

Safety Technology Institute

21020 Ispra (Varese)

ITALY

Giovanni Saponaro

ENEA

Natl. Comm. for R\&D of Nuclear Energy

Via Vitaliano Brancati, 48

00144 Rome

ITALY

Japan Atomic Energy Research Institute (4)

Attn: Kunihisa Soda

Jun Sugimoto

Norihiro Yamano

Y. Maruyama

Tokai-mura, Naka-gun, Ibarr.ki-ken

319-11

JAPAN

Dr. Masayoshi Shiba, Director General

Institute of Nuclear Safety

Nuclear Power Engineering Corporation

Fujita Kankou Toranoman Bldg. 7F

3-17-1, Toranoman

Minato- $\mathrm{Ku}$, Tokyo, 105

JAPAN

Akira Nonaka, Manager

Equipment and Components Department

NUPEC

Nuclear Power Engineering Center

Shuwa-kamigacho Bldg.

3-13, 4-Chome, Toranomon Minato-ku

Tokyo 105

JAPAN 
Kenji Takumi

Director and General Manager

Equipment and Components Department

Nuclear Power Engineering Center

Shuwa-kamigacho Bldg.

3-13, 4-Chome, Toranomon Minato-ku

Tokyo 105

JAPAN

Masao Ogino

Mitsubishi Atomic Power Industries

4-1 Shibakoen 2-Chome

Minatoku Tokyo

JAPAN

Hidetoshi Okada

Nuclear Power Engineering Corporation

3-17-1, Toranomon Bldg. 5F

Minato-ku, Tokyo 105

JAPAN

Hirohide Oikawa

'Toshiba Corporation

8, Shin-Sugita, Isogo-ku

Yokohama

JAPAN

Korea Atomic Energy Research Inst. (3)

Attn: Kun-Joong Yoo

Song-Won Cho

Dong-Ha Kim

P. O. Box 7, Dacduk Danji

Taejon

SOUTH KOREA 305-35.3

Jae Hong Park

Safety Assessment Department

Korea Atomic Energy Research Institute

P. O. Box 16, Daeduk-Danji

Taejon

SOUTH KORK $: 305-353$ 
Kim, Han Chul, Senior Researcher

Severe Accident Assessment Department.

Korea Atomic Energy Research Institute

P. O. Box 16

Kaeduk-Danji

Taejon

SOUTH KrREA 305-606

Netherlands Energy Research Foundation (2)

Attn: Karel J. Brinkmann

$$
\text { E. J. Velema }
$$

P. O. Box 1

1755 ZG Petten

THE NETHERLANDS

Dr. Valery F. Strizhov

Russian Academy of Science

Institute of Nuclear Safety

Moscow, G. Tulsky, 52

113191, RUSSIA

Universidad Politecnica de Madrid (2)

Attn: Augustin Alonzo Santos Francisco Martin

E.T.S. Ingenieros Industriales

Jose Gutierrez Abascal, 2

28006 Madrid

SPAIN

Juan Bagues

Consejo de Seguridad Nuclear

Justo Dorado, 11

28040, Madrid

SPAIN

Oddbjörn Sandervåg

Statens Kärnkraftinspektion

Swedish Nuclear Power Inspectorate

Box 2710610252 Stockholm

SWEDEN 
1. Hammar, Director

Division of Research

Swedish Nuclear Power luspectorate

Statens Karnkraftinspektion

Sehlstedtsgatan 11

Box 27106

S-102-50 Stockholm

SWEDEN

Swiss Federal Nuclear Safety Inspectorate (4)

Attn: S. Chakraborty

Sang lung Chan

U. Schmocker

H. P. Isaak

CH-5232 Villigen-HSK

SWITZERLAND

United Kingdom Atomic Energy Agency (7)

Winfrith 'Technology Center

Attn: T. Haste

S. R. Kinnersley

D. W. Sweet

A. Nichols, 102/A50

B. Bowsher, $105 \mathrm{~A} / \mathrm{A} 50$

D. Williams, 01/A50

J. Mitchell, 210/A32

Winfrith, Dorchester

Dorset, DT2 8DH, England

UNITED KINGIOM

United Kingdom Atomic Energy Authority (2)

Safety \& Reliability Directorate

Attn: M. I. Robertson

C. Wheatley

Wigshaw Lane, Culcheth, Warrington

Cheshire, WA3 4NE

UNITED KINGDOM 
Internal Distribution:

MS1328 R. S. Longenbaugh, 6342

MS0736 N. I. Ortiz, 6400

MS0744 W. A. von Riesemann, 6403

MS0744 D. A. Powers, 6404

MS0747 A. L. Camp, 6412

MS0747 S. E. Dingman, 6412

MS0748 F. T. Harper, 6413

MS0742 J. E. Kelly, 6414

MS0745 S. L. Thompson, 6418 (5 copies)

MS0745 R. K. Cole, 6418

MS0745 A. A. Elsbernd, 6418

MS0745 L. N. Kmetyk, 6418 (5 copies)

MS0745 R. C. Smith, 6418

MS0745 D. S. Stuart, 6418

MS0745 R. M. Summers, 6418

MS0745 T. J. Tautges, 6418

MS1137 N. Bixler, 6422

MS1137 T. J. Heames, 6422

MS1139 R. C. Schmidt, 6423

MS0739 K. E. Washington, 6429

MS0899 Technical Library, 7141 (5 copies)

MS0619 Technical Publications, 7151

MS0100 Document Processing for DOE/OSTI, 7613-2 (10 copies)

MS9018 Central Technical Files, 8523-2 
